\title{
Estimate of changes in agricultural terrestrial nitrogen pathways and ammonia emissions from 1850 to present in the Community Earth System Model
}

\author{
Stuart Riddick ${ }^{1,2, b}$, Daniel Ward ${ }^{3, a}$, Peter Hess ${ }^{1}$, Natalie Mahowald ${ }^{3}$, Raia Massad ${ }^{4}$, and Elisabeth Holland ${ }^{5}$ \\ ${ }^{1}$ Department of Biological and Environmental Engineering, Cornell University, Ithaca, NY, USA \\ ${ }^{2}$ Centre for Atmospheric Science, Department of Chemistry, University of Cambridge, Cambridge, UK \\ ${ }^{3}$ Department Earth and Atmospheric Sciences, Cornell University, Ithaca, NY, USA \\ ${ }^{4}$ INRA, AgroParisTech, UMR1402 ECOSYS, 78850 Thiverval-Grignon, France \\ ${ }^{5}$ Pacific Centre for Environment and Sustainable Development, University of the South Pacific, Suva, Fiji \\ anow at: Atmospheric and Oceanic Sciences, Princeton University, Princeton, USA \\ ${ }^{b}$ now at: Department of Civil and Environmental Engineering, Princeton University, Princeton, NY, USA
}

Correspondence to: Peter Hess (pgh25@cornell.edu)

Received: 12 August 2015 - Published in Biogeosciences Discuss.: 28 September 2015

Revised: 6 May 2016 - Accepted: 12 May 2016 - Published: 13 June 2016

\begin{abstract}
Nitrogen applied to the surface of the land for agricultural purposes represents a significant source of reactive nitrogen $\left(\mathrm{N}_{\mathrm{r}}\right)$ that can be emitted as a gaseous $\mathrm{N}_{\mathrm{r}}$ species, be denitrified to atmospheric nitrogen $\left(\mathrm{N}_{2}\right)$, run off during rain events or form plant-useable nitrogen in the soil. To investigate the magnitude, temporal variability and spatial heterogeneity of nitrogen pathways on a global scale from sources of animal manure and synthetic fertilizer, we developed a mechanistic parameterization of these pathways within a global terrestrial land model, the Community Land Model (CLM). In this first model version the parameterization emphasizes an explicit climate-dependent approach while using highly simplified representations of agricultural practices, including manure management and fertilizer application. The climate-dependent approach explicitly simulates the relationship between meteorological variables and biogeochemical processes to calculate the volatilization of ammonia $\left(\mathrm{NH}_{3}\right)$, nitrification and runoff of $\mathrm{N}_{\mathrm{r}}$ following manure or synthetic fertilizer application. For the year 2000, approximately $125 \mathrm{Tg} \mathrm{N} \mathrm{yr}^{-1}$ is applied as manure and $62 \mathrm{Tg} \mathrm{N} \mathrm{yr}^{-1}$ is applied as synthetic fertilizer. We estimate the resulting global $\mathrm{NH}_{3}$ emissions are $21 \mathrm{Tg} \mathrm{Nyr}^{-1}$ from manure (17\% of manure production) and $12 \mathrm{Tg} \mathrm{N} \mathrm{yr}^{-1}$ from fertilizer (19\% of fertilizer application); reactive nitrogen runoff during rain events is calculated as $11 \mathrm{Tg} \mathrm{N} \mathrm{yr}^{-1}$ from manure
\end{abstract}

and $5 \mathrm{Tg} \mathrm{N} \mathrm{yr}^{-1}$ from fertilizer. The remaining nitrogen from manure ( $93 \mathrm{Tg} \mathrm{N} \mathrm{yr}^{-1}$ ) and synthetic fertilizer $\left(45 \mathrm{Tg} \mathrm{N} \mathrm{yr}^{-1}\right)$ is captured by the canopy or transferred to the soil nitrogen pools. The parameterization was implemented in the CLM from 1850 to 2000 using a transient simulation which predicted that, even though absolute values of all nitrogen pathways are increasing with increased manure and synthetic fertilizer application, partitioning of nitrogen to $\mathrm{NH}_{3}$ emissions from manure is increasing on a percentage basis, from $14 \%$ of nitrogen applied in $1850\left(3 \mathrm{Tg} \mathrm{NH}_{3} \mathrm{yr}^{-1}\right)$ to $17 \%$ of nitrogen applied in $2000\left(21 \mathrm{Tg} \mathrm{NH}_{3} \mathrm{yr}^{-1}\right)$. Under current manure and synthetic fertilizer application rates we find a global sensitivity of an additional $1 \mathrm{Tg} \mathrm{NH}_{3}$ (approximately $3 \%$ of manure and fertilizer) emitted per year per ${ }^{\circ} \mathrm{C}$ of warming. While the model confirms earlier estimates of nitrogen fluxes made in a range of studies, its key purpose is to provide a theoretical framework that can be employed within a biogeochemical model, that can explicitly respond to climate and that can evolve and improve with further observation. 


\section{Introduction}

Nitrogen is needed by all living things for growth. However, it is relatively inert in its most abundant form, diatomic nitrogen $\left(\mathrm{N}_{2}\right)$, and needs to be converted to a form of reactive nitrogen $\left(\mathrm{N}_{\mathrm{r}}\right)$ before it can be used by most plants for growth (Visek, 1984). Supplying sufficient $\mathrm{N}_{\mathrm{r}}$ for maximum crop yield is a major concern in agriculture. In preindustrial times $\mathrm{N}_{\mathrm{r}}$ demand was partly solved with the use of animal manure and seabird guano as well as crop rotation and the use of nitrogen-fixing crops (Smil, 2000). However, by the early 20th century the supply of these $\mathrm{N}_{\mathrm{r}}$ sources could not match the demands of an increasing population and the Haber-Bosch process of creating synthetic $\mathrm{N}_{\mathrm{r}}$ was developed (Galloway et al., 2004).

The use of $\mathrm{N}_{\mathrm{r}}$ to improve crop yield has become an environmental concern as $\mathrm{N}_{\mathrm{r}}$ in synthetic fertilizer and manure cascades through the soil, water and the atmospheric nitrogen cycles. Plants can readily use applied $\mathrm{N}_{\mathrm{r}}$ for plant growth; however, $\mathrm{N}_{\mathrm{r}}$ washed off fields or volatilized as gas can reduce ecosystem biodiversity through acidification and eutrophication (Sutton et al., 2013). Increased $N_{r}$ in the hydrosphere can lead to the subsequent degradation of riverine and nearshore water quality as the water becomes more acidic and the growth of primary producers blooms (Turner and Rabalais, 1991; Howarth et al., 2002), which can alter the local interspecies competition and biodiversity (Sutton et al., 2012). Reactive nitrogen emissions into the atmosphere impact air quality through the ozone generation associated with the emissions of nitrogen oxide (e.g., Hudman et al., 2010) and the contribution of ammonia $\left(\mathrm{NH}_{3}\right)$ to aerosol formation (e.g., Gu et al., 2014). Nitrogen cycling also impacts climate through the stimulation of plant growth and the associated increase in carbon storage; through the associated emissions of $\mathrm{N}_{2} \mathrm{O}$, a strong greenhouse gas; through emissions of nitrogen oxides and the associated ozone production; and through the emissions of $\mathrm{NH}_{3}$, with its potential to cool the climate through aerosol formation (e.g., Adams et al., 2001).

As a result of their dependence on environmental conditions, $\mathrm{N}_{\mathrm{r}}$ pathways following manure or synthetic fertilizer application are likely to change as the climate changes. This study describes a biogeochemically consistent processdriven parameterization suitable for use in Earth system models for simulating $\mathrm{N}_{\mathrm{r}}$ flows following the addition of $\mathrm{N}_{\mathrm{r}}$ as manure or synthetic fertilizer. The parameterization is evaluated against local measurements of $\mathrm{NH}_{3}$ fluxes and against global $\mathrm{NH}_{3}$ flux estimates. This parameterization allows simulations of the coupling between the nitrogen cycle and climate to explicitly include $\mathrm{NH}_{3}$ emissions and the $\mathrm{N}_{\mathrm{r}}$ runoff from manure and synthetic fertilizer application. To our knowledge, no Earth system model has yet to explicitly predict changing nitrogen pathways from manure and synthetic fertilizer in response to climate. We note at the outset that the representation of agricultural processes is highly simplified in the initial model version described here.
Sources of $\mathrm{N}_{\mathrm{r}}$ largely fall into two categories: "new" sources, created by chemical and biological processes, and those that are "recycled", such as manure excretion by animals. The largest natural new $\mathrm{N}_{\mathrm{r}}$ creation is by biological nitrogen fixers found in the ocean, biological nitrogen fixers on land, and as the by-product of lightning estimated at $140 \mathrm{Tg} \mathrm{Nyr}^{-1} \pm 50 \%, 58 \mathrm{Tg} \mathrm{N} \mathrm{yr}^{-1} \pm 50 \%$ and $5 \mathrm{Tg} \mathrm{Nyr}^{-1} \pm 50 \%$, respectively (Fowler et al., 2013). The dominant anthropogenic sources of new $\mathrm{N}_{\mathrm{r}}$ are HaberBosch-derived fertilizer (estimated at $120 \mathrm{Tg} \mathrm{N} \mathrm{yr}^{-1} \pm 10 \%$ in 2005), the burning of fossil fuels ( $30 \mathrm{Tg} \mathrm{N} \mathrm{yr}^{-1} \pm 10 \%$ in 2000), and a further $60 \mathrm{Tg} \mathrm{N} \mathrm{yr}^{-1} \pm 30 \%$ (ca. 2005) from biological nitrogen fixers grown for human consumption, such as legumes (Fowler et al., 2013). Since preindustrial times, anthropogenic $\mathrm{N}_{\mathrm{r}}$ creation has increased from $15 \mathrm{Tg} \mathrm{N} \mathrm{yr}^{-1}$ to the present estimate of $210 \mathrm{Tg} \mathrm{N} \mathrm{yr}^{-1}$ (Galloway et al., 2004; Fowler et al., 2013).

Animal manure is used to stimulate plant growth in agriculture. It contains $\mathrm{N}_{\mathrm{r}}$ recycled from the soil produced when animals eat plants. A comprehensive increase in livestock population is estimated to have increased global manure production from $21 \mathrm{Tg} \mathrm{Nyr}^{-1}$ in 1850 to the present estimate of $141 \mathrm{Tg} \mathrm{N} \mathrm{yr}^{-1}$ (Holland et al., 2005). It is suggested that this increase in recycled $\mathrm{N}_{\mathrm{r}}$ production speeds up the decay and processing of plant biomass, releasing different $\mathrm{N}_{\mathrm{r}}$ products to the atmosphere when compared to natural decay processes (Davidson, 2009).

Projections of agricultural activity (Bodirsky et al., 2012) suggest continued increases in the application of synthetic fertilizers until the mid-21st century (and possibly beyond) concurrent with increases in manure production (Tilman et al., 2001). In addition to the increased use of organic and synthetic fertilizers in the future, $\mathrm{NH}_{3}$ emissions are expected to increase because of the impact of changing climate on nitrogen biogeochemistry (Tilman et al., 2001; Skjøth and Geels, 2013; Sutton et al., 2013). Skjøth and Geels (2013) predict increases in future $\mathrm{NH}_{3}$ emissions of up to $60 \%$ over Europe by 2100 , largely due to increased $\mathrm{NH}_{3}$ emissions with temperature. Sutton et al. (2013) predict future temperature increases may enhance global $\mathrm{NH}_{3}$ emissions by up to approximately $40 \%$ assuming a $5{ }^{\circ} \mathrm{C}$ warming. In addition to future changes in climate-induced $\mathrm{NH}_{3}$ volatilization from manure and synthetic fertilizer application, future changes in agro-management practices, soil microbiological processes and nitrogen runoff may also be expected.

Current estimates of the direct forcing of nitrate aerosols present as ammonium nitrate encompass the range from -0.03 to $-0.41 \mathrm{Wm}^{-2}$ in the ACCMIP (Atmospheric Chemistry and Climate Model Intercomparison Project) (Shindell et al., 2013) and AeroCom Phase II (Myhre et al., 2013) simulations. With a future reduction in sulfate emissions the relative importance of nitrate aerosols is expected to dominate the direct aerosol forcing by 2100 , with a resulting increase in radiative forcing of up to a factor of 8.6 over what it would have been without accounting for nitrate aerosols (Hauglus- 
taine et al., 2014). These estimates do not consider the impact of climate change on $\mathrm{NH}_{3}$ emissions.

Modeling studies calculating $\mathrm{NH}_{3}$ emission from manure and synthetic fertilizer have broadly fallen into two categories: models that use empirically derived agriculturally based emission factors and more complex processbased models. Global emissions have almost been universally estimated using the former approach. Emission factors were used by Bouwman et al. (1997) to estimate global $\mathrm{NH}_{3}$ emissions in 1990 of $54 \mathrm{Tg} \mathrm{Nyr}^{-1}$, with an emission of $21.6 \mathrm{Tg} \mathrm{N} \mathrm{yr}^{-1}$ from domestic animals (Bouwman et al., 1997). Beusen et al. (2008) also used emission factors to estimate global $\mathrm{NH}_{3}$ emission from agricultural livestock (21 $\left.\mathrm{Tg} \mathrm{N} \mathrm{yr}^{-1}\right)$ and synthetic fertilizers $\left(11 \mathrm{Tg} \mathrm{N} \mathrm{yr}^{-1}\right)$ in 2000; Bouwman et al. (2013) estimated emissions of $34 \mathrm{Tg} \mathrm{NH}_{3} \mathrm{yr}^{-1}$ on agricultural land, with $10 \mathrm{Tg} \mathrm{NH}_{3} \mathrm{yr}^{-1}$ from animal housing. A number of more recent global models have included emission factors explicitly as a function of temperature (e.g., Huang et al., 2012; Paulot et al., 2014). Paulot et al. (2014) estimate current global $\mathrm{NH}_{3}$ emissions of $9.4 \mathrm{Tg} \mathrm{yr}^{-1}$ for synthetic fertilizer and $24 \mathrm{Tg} \mathrm{yr}^{-1}$ for manure.

Alternatively, process-based or mechanistic models have been developed that estimate $\mathrm{N}_{\mathrm{r}}$ flows, equilibria and transformations between different nitrogen species as well as $\mathrm{N}_{\mathrm{r}}$ emissions from synthetic fertilizer and manure. Process models have been used on the field to regional scale, but not on the global scale. These models generally do not simulate the runoff of $\mathrm{N}_{\mathrm{r}}$. For example, Génermont and Cellier (1997) simulate the emissions of $\mathrm{NH}_{3}(\mathrm{~g})$ to the atmosphere after considering the physical and chemical equilibria and transfer of $\mathrm{Nr}$ species $\left(\mathrm{NH}_{3}(\mathrm{~g}), \mathrm{NH}_{3}(\mathrm{aq})\right.$, and $\left.\mathrm{NH}_{4}^{+}(\mathrm{aq})\right)$ in the soil. The resulting model is used to calculate the $\mathrm{NH}_{3}$ emissions from synthetic fertilizer over France within the air quality model, Chimere (Hamaoui-Laguel et al., 2014). Other examples include Pinder et al. (2004), who describe a process model of $\mathrm{NH}_{3}$ emissions from a dairy farm, while $\mathrm{Li}$ et al. (2012) describe a farm-scale process model of the decomposition and emission of $\mathrm{NH}_{3}$ from manure.

The overall goal of this paper is to describe and analyze a global model capable of simulating nitrogen pathways from manure and synthetic fertilizer added to the surface of the land under changing climatic conditions. The model will allow for a better global quantification of the climate, health and environmental impacts of a changing nitrogen cycle under climate change. The resulting model is designed out of necessity for use within an Earth system model so as to simulate the interactions between the climate and the carbon and nitrogen cycles. Section 2 presents the overall methodology used here including a detailed description of the process model used to calculate climate-dependent nitrogen pathways. Section 3 analyzes the model and includes a comparison of simulated vs. site level measurements of $\mathrm{NH}_{3}$ fluxes, an analysis of the globally heterogeneous nitrogen pathways from applied manure and synthetic fertilizer over a range of climatic regimes, model predictions for changes in nitrogen pathways from 1850 to present and the sensitivity of the results to model parameters. Section 4 gives our conclusions.

\section{Methods}

In this section we describe a process model for the flow of agricultural nitrogen (FAN) that simulates $\mathrm{NH}_{3}$ emissions and other $\mathrm{N}_{\mathrm{r}}$ flows from applied manure and synthetic fertilizer applications, including their spatial and temporal variations, within an Earth system model, the Community Earth System Model 1.1 (CESM1.1). The FAN process model developed here simulates the incorporation of manure and fertilizer $\mathrm{N}_{\mathrm{r}}$ into soil organic matter and soil nitrogen pools (Chambers et al., 1999), its volatilization as $\mathrm{NH}_{3}$ to the atmosphere and the direct runoff of $\mathrm{N}_{\mathrm{r}}$ from the surface (Fig. 1). The model is global in nature, is designed to conserve carbon and nitrogen, and responds to changes in climate. It is designed to provide an interface between the application of manure and synthetic fertilizer and the nitrogen cycling developed within the Community Land Model 4.5 (CLM4.5), the land component of the CESM.

Nitrogen pathways subsequent to the application of manure or synthetic fertilizer depend on the complex interaction between both human and natural processes. In particular they depend on the biology and physics of the applied substrate, agricultural practices and climate. Bottom-up emission inventories with specified emission factors that take into account the animal feed, the type of animal housing, if any, and the field application of the synthetic fertilizer or manure (e.g., Bouwman et al., 1997) are generally used in global chemistry and chemistry-climate applications. For example, this type of emission inventory (e.g., Lamarque et al., 2010) was used in the Atmospheric Chemistry and Climate Model Intercomparison Project (ACCMIP) (Lamarque et al., 2013a) for assessing historical and future chemistry-climate scenarios and in assessing nitrogen deposition (Lamarque et al., 2013b) with implications for the carbon cycle. However, these inventories include very simplified representations of the effect of climate on emissions, for example, by grouping countries into industrial or developing categories (Bouwman et al., 1997). A seasonal emission dependence is not implicit in these bottom-up inventories although sometimes an empirical relationship is applied (e.g., Adams et al., 2001; also see Skjøth et al., 2011).

In the first application of the model described here we take the opposite tact. We have minimized the description of agricultural practices, and instead emphasize the physically based climate-dependent biogeochemistry of manure and synthetic fertilizer decomposition and the resultant nitrogen pathways. While traditional bottom-up $\mathrm{NH}_{3}$ emission inventories reflect regional differences in agro-management practices and the resulting regional differences in $\mathrm{NH}_{3}$ emissions, they do not account for physically based geographical 


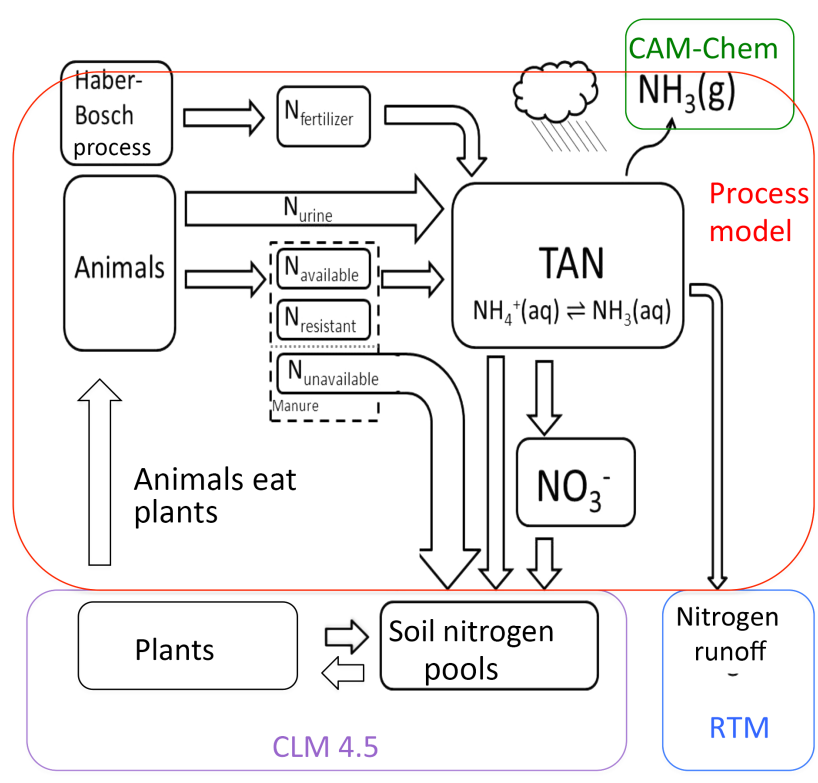

Figure 1. Schematic of the addition of the FAN (flow of agricultural nitrogen) process model to the CESM nitrogen cycle. Some minor pathways are not shown. Soil nitrogen pools and plant nitrogen exist in CLM4.5. Urine nitrogen $\left(\mathrm{N}_{\text {urine }}\right)$ is directly input to the TAN pool, while fecal matter is split into three parts that decompose into the TAN pool at a rate determined by their $\mathrm{C}: \mathrm{N}$ ratio $\left(\mathrm{N}_{\text {available, }}\right.$, $\mathrm{N}_{\text {resistant }}, \mathrm{N}_{\text {unavailable }}$ ). Manure nitrogen that does not mineralize $\left(\mathrm{N}_{\text {unavailable }}\right)$ is added to the soil organic nitrogen pool. Nitrogen applied as synthetic fertilizer is added to the $\mathrm{N}_{\text {fertilizer }}$ pool where it decomposes into the TAN pool. Losses from the TAN pool include ammonia $\left(\mathrm{NH}_{3}\right)$ emission (into CAM-chem), nitrogen runoff (into the RTM), nitrate $\left(\mathrm{NO}_{3}^{-}\right)$formation and diffusion to the soil nitrogen pools.

and meteorological influences, including temperature, atmospheric mixing and rainfall. However, these influences are accounted for in the parameterization described below. As with regional differences in agro-management practices, meteorological impacts may also induce large regional and interannual variations in $\mathrm{NH}_{3}$ emissions. For example, increasing the ground temperature from 290 to $300 \mathrm{~K}$ (at a pH of 7) increases the $\mathrm{NH}_{3}$ emissions by a factor of 3 (see Sect. 2.2.6).

We recognize in this first application that we are simplifying many important agro-management processes. First, we assume that all synthetic fertilizer is urea and the $\mathrm{pH}$ of the soil is given. Different applied synthetic fertilizers have a strong impact on the $\mathrm{pH}$ of the soil-fertilizer mixture with the overall emission factor very dependent on the $\mathrm{pH}$ (Whitehead and Raistrick, 1990). Urea is the most commonly used synthetic fertilizer accounting for over $50 \%$ of the global nitrogenous synthetic fertilizer usage (Gilbert et al., 2006) and has one of the highest emission factors for commonly used synthetic fertilizers (Bouwman et al., 1997). Emission factors for other types of fertilizers can be significantly smaller. Thus the estimates here for fertilizer $\mathrm{NH}_{3}$ emissions may be considered as an upper estimate. Second, we do not account for manure management practices. Instead we assume all manure is continuously spread onto fields. In a global study Beusen et al. (2008) considered four primary pathways for manure nitrogen: (i) manure nitrogen lost from the system ( $14 \%$ of the manure nitrogen, range 5-26\%), (ii) manure nitrogen excreted in animal houses followed by storage and subsequent spreading onto croplands $(35 \%$ of manure nitrogen; range $24-51 \%$ ), (iii) manure nitrogen excreted in animal houses followed by storage and subsequent spreading onto pasture lands (7\% of manure nitrogen; range $3-11 \%$ ), and (iv) manure nitrogen excreted by grazing animals onto pastures ( $44 \%$ of manure nitrogen; range $29-59 \%$ ). Of the $42 \%$ of manure nitrogen excreted in housing, $20 \%$ (range: $12-28 \%$ ) is emitted as $\mathrm{NH}_{3}$ from housing and storage facilities (Beusen et al., 2008). An additional 15-23\% of the remaining manure nitrogen is emitted as $\mathrm{NH}_{3}$ (range: $11-30 \%$ ) after it is spread onto crop or pasture land. Of the $44 \%$ of manure nitrogen excreted by grading animals on pasture land $11-12 \%$ (range 6-17\%) is emitted as ammonia. Considering these various pathways the overall emission factor for manure nitrogen is estimated as $19 \%$ in Beusen et al. (2008) (compare with $17 \%$ in this study). Third, we do not account for specific fertilizer application techniques. For example, the soil incorporation of manure leads to a $50 \%$ reduction in $\mathrm{NH}_{3}$ emissions compared to soil broadcasting (Bouwman et al., 2002). We recognize that there are large spreads in all these ranges and that regional practices may alter these numbers, although large errors may be unavoidable due to insufficient characterization of regional agro-management practices.

In the present application we also simplify the representation of $\mathrm{NH}_{3}$ fluxes to the atmosphere. The aerodynamic resistances used to compute the flux of $\mathrm{NH}_{3}$ to the atmosphere are calculated with CLM4.5, but due to the configuration of the CLM they are not calculated at the plant function type (PFT) level. Instead, the canopy capture of the $\mathrm{NH}_{3}$ flux is calculated as a global number. The high spatial heterogeneity of $\mathrm{NH}_{3}$ emissions may preclude an accurate local representation of exchange processes on the approximately $2 \times 2^{\circ}$ grid cell used here, although even on similar coarse resolutions Zhu et al. (2015) show the implementation of a bidirectional scheme has significant global and pronounced regional impacts. Nevertheless, the simulation of dynamic $\mathrm{NH}_{3}$ emissions, as described below, with $\mathrm{NH}_{3}$ emissions responding to temperature on the model time step is a first step towards more accurately coupling terrestrial $\mathrm{NH}_{3}$ fluxes with the atmosphere.

A number of requirements are necessary to model $\mathrm{NH}_{3}$ emissions following synthetic fertilizer or manure application within an Earth system model, specifications that are not necessary in more traditional formulations. (1) The model must be global in nature to characterize global interactions between applied $\mathrm{N}_{\mathrm{r}}$ and climate. (2) The model must conserve nitrogen. In particular the nitrogen associated with ma- 
nure does not add new nitrogen to the system, but merely represents a recycling of available nitrogen. Artificial sources or sinks of nitrogen may have serious repercussions, especially when simulating the global nitrogen cycle on the timescale of centuries. (3) The model must be able to simulate the changing impact of climate on the fate of manure and synthetic fertilizer $\mathrm{N}_{\mathrm{r}}$. In particular, $\mathrm{NH}_{3}$ emissions are sensitive to both temperature and the water content of the soil. In addition, the runoff of $\mathrm{N}_{\mathrm{r}}$ is likely to change under climate change. The process model developed here is capable of simulating the physics of changing nitrogen pathways under a changing climate.

An ideal model would incorporate a globally explicit representation of agro-management practices, including manure treatment (housing, storage and spreading) and fertilizer application (e.g., see Sutton et al., 2013). It would also include an explicit representation of the bidirectional exchange of $\mathrm{NH}_{3}$ between the land and atmosphere, including the incorporation of PFT dependent canopy deposition and aerodynamic resistances. While the model developed here captures many of the regional and global features seen in models based on emission factors, here we emphasize the importance of regional and climatic changes in meteorology.

\subsection{Relation between the FAN process model and the CESM1.1}

The parameterization developed here acts as the interface between specified manure and synthetic fertilizer application and the CESM1.1. The CESM1.1 simulates atmospheric, ocean, land and sea ice processes, linked together using a coupler, and includes a land and ocean carbon cycle (Hurrell et al., 2013; Lindsay et al., 2014). The CESM participates in the Climate Model Intercomparison Project (CMIP5) and has been extensively evaluated in the literature (see Hurrell et al., 2013). The land model within the CESM1.1, CLM 4.5, includes representation of surface energy and water fluxes, hydrology, phenology, and the carbon cycle (Lawrence et al., 2007; Oleson et al., 2008). CLM4.5 retains the basic properties of the previous model version (CLM4), which has been extensively tested and evaluated by many studies at the global (Lawrence et al., 2007; Oleson et al., 2008; Randerson et al., 2009) and the site (Stoeckli et al., 2008; Randerson et al., 2009) scale. CLM4.5 includes improvements to better simulate: (1) water and momentum fluxes at the Earth's surface; (2) carbon and nitrogen dynamics within soils and (3) precipitation runoff rates (Koven et al., 2013). CLM4.5 simulations can be forced by meteorology (as done here), or as a part of a coupled carbon-climate model (Lawrence et al., 2007; Oleson et al., 2008). The current version of the carbon model is an improved version of the coupled carbonclimate model used in Keppel-Aleks et al. (2013), Lindsay et al. (2014) and Thornton et al. (2009). The carbon model includes a nitrogen limitation on land carbon uptake, described in Thornton et al. $(2007,2009)$. Further improvements have been made to the below ground carbon cycle, as well as other elements of the land model in order to improve its performance (e.g., Koven et al., 2013; Lawrence et al., 2012). The impact of increases in nitrogen deposition (from fossil fuels, fires and agriculture; Lamarque et al., 2010) have been evaluated (Thornton et al., 2007, 2009) and extensively compared to observations (e.g., Thomas et al., 2013).

As described in Koven et al. (2013), CLM4.5 simulates the basic flows of $\mathrm{N}_{\mathrm{r}}$ within soils following the Century $\mathrm{N}$ model (Parton et al., 1996, 2001; Del Grosso et al., 2000), including the processes of nitrification, denitrification, and emissions of $\mathrm{N}_{\mathrm{r}}$ and $\mathrm{N}_{2}$ and the loss of $\mathrm{N}_{\mathrm{r}}$ from leaching and runoff. CLM4.5 also simulates the transfer of $\mathrm{N}_{\mathrm{r}}$ between soils and vegetation, and the loss of $\mathrm{N}_{\mathrm{r}}$ from fire. Sources of $\mathrm{N}_{\mathrm{r}}$ within CLM4.5 are from biological nitrogen fixation and from surface deposition. The process model developed here adds an additional source of $\mathrm{N}_{\mathrm{r}}$ to CLM4.5, the addition of synthetic fertilizer. It also adds an additional pathway whereby $\mathrm{N}_{\mathrm{r}}$ is recycled: the creation and application of manure (Fig. 1).

The relation between nitrogen cycling within the FAN process model developed here and that within the atmospheric, land and river components of the Community Earth System Model (CESM1.1) is given in Fig. 1. In this first study the subsequent fate of $\mathrm{N}_{\mathrm{r}}$ from synthetic fertilizer or manure application after it is incorporated into the soil organic matter or the soil nitrogen pools of CLM4.5 is not considered (see Fig. 1). As described in more detail below, synthetic fertilizer and manure are not applied to particular PFTs (e.g., pasture or grassland) within CLM4.5. This is because soil related properties including soil nitrogen are not specified at the PFT level within CLM4.5, but instead are specified at the column level that includes many PFTs. In practice we expect that the impact of this contamination across PFTs will be small since the major $\mathrm{N}$-application regions (central US, northern India, eastern China) are not PFT-diverse but contain almost exclusively crop and grass PFTs.

Note that as a first approximation the model described here does not simulate the direct emission loss of species other than $\mathrm{NH}_{3}$. Atmospheric emission losses of $\mathrm{N}_{2} \mathrm{O}$ or $\mathrm{N}_{2}$ (and potentially $\mathrm{NO}_{x}$ ) are simulated in CLM4.5 (Koven et al., 2013), the land component model of the CESM1.1, "downstream" from the pathways explicitly considered here. In addition, the fate of $\mathrm{N}_{\mathrm{r}}$ emitted into the atmosphere as $\mathrm{NH}_{3}$ directly from synthetic fertilizer or manure is handled by the atmospheric chemistry component of the CESM (CAM-chem) and is not considered here (Fig. 1). The runoff of $\mathrm{N}_{\mathrm{r}}$ from manure or synthetic fertilizer nitrogen pools has been coupled to the river transport model (RTM) in Nevison et al. (2016) (Fig. 1) but is also not considered here.

\subsection{FAN process model}

A schematic of the overall model is given in Fig. 1. All the equations and variables used in the model are presented in the Appendix. The assumptions used in constructing this model 
are detailed below where appropriate. Sensitivity to model parameters is given in Sect. 3.4. The $\mathrm{N}_{\mathrm{r}}$ pathways are calculated separately for manure and synthetic fertilizer. While this model assumes that synthetic fertilizer application and manure application can take place in the same approximately $2 \times 2^{\circ}$ grid cell, we assume that manure and synthetic fertilizer are not applied in the exactly the same place. Therefore the $\mathrm{NH}_{3}$ emissions, the nitrogen incorporation into soil pools, and the nitrogen runoff are separately calculated for manure and synthetic fertilizer in each column. This means that the total ammoniacal nitrogen (TAN) pools (consisting of $\mathrm{NH}_{3}(\mathrm{~g}), \mathrm{NH}_{3}(\mathrm{aq})$, and $\mathrm{NH}_{4}^{+}$) for manure and synthetic fertilizer are discrete and hence the nitrogen pathways are not combined.

The application rate and geographical distribution used for manure and synthetic fertilizer application is taken from the synthetic fertilizer application and manure production data sets developed in Potter et al. (2010). These data sets are valid for ca. 2000 for synthetic fertilizer and 2007 for manure (Potter et al., 2010). As discussed above we assume that manure is continuously spread onto fields, by-passing the use of animal houses and storage. Manure and synthetic fertilizer is assumed to be spread across all PFTs in CLM4.5, as these share a common nitrogen pool. Future model versions will refine these initial assumptions.

To adequately model the conversion from manure to TAN it is necessary to separate the manure into four different pools depending on the decomposition timescales (Sects. 2.2.1 and 2.2.2 and Fig. 1). A similar strategy was adopted by Li et al. (2012) for manure and is commonly used in simulating litter decomposition. Synthetic fertilizer $\mathrm{N}_{\mathrm{r}}$ is added to one pool, whereafter it decomposes into the TAN pool (Fig. 1). Once in the TAN pool $\mathrm{N}_{\mathrm{r}}$ (1) washes off during rain events (Brouder et al., 2005); (2) volatilizes as $\mathrm{NH}_{3}$ (Sutton et al., 1994; Nemitz et al., 2000), whereafter it is redeposited onto the canopy (not shown) or enters the atmospheric flow; (3) nitrifies to form nitrate $\left(\mathrm{NO}_{3}^{-}\right.$) (Stange and Neue, 2009); or (4) is incorporated into the soil nitrogen pools. Nitrate, in turn, becomes incorporated into the soil (Fig. 1). A number of other smaller loss processes are not explicitly simulated.

Manure must be added to the model in such a manner as to conserve nitrogen (Fig. 1). Here, we assume animals consume carbon and nitrogen from plants and then subsequently excrete this as manure. Within the CLM, carbon and nitrogen in the plant-leaf pool is thus converted to carbon and nitrogen in manure, conserving overall carbon and nitrogen. The conversion rate from carbon and nitrogen in plants to that in manure is set to equal the rate of manure production. The external data set of Potter (2010) gives the rate of $\mathrm{N}_{\mathrm{r}}$ production from animals, and thus allows us to specify the nitrogen flows. The specified $\mathrm{C}$ to $\mathrm{N}$ ratio in the plant-leaf pool determines the associated carbon flows due to ruminant consumption of plant material. The input manure production rate from animals implicitly includes that produced from transported feed. Thus the subsequent $\mathrm{NH}_{3}$ emission rate includes the nitrogen contained in transported feed grown elsewhere. Here we make the simplification that the consumption rate of plant matter to balance the manure production is local. That is, we do not explicitly consider the import of animal feed to match the carbon and nitrogen flows associated with manure production. While this is not entirely consistent, the development of the requisite data set for feedstock flows from 1850 2000 is outside the scope of this study. We do not know of an Earth system model that does consider the anthropogenic import of nitrogen or carbon. This inconsistency could produce cases where there is insufficient local plant material to balance the overall manure and urine production, but this is generally not the case. The parameterization also ignores export of $\mathrm{N}_{\mathrm{r}}$ in ruminant products such as milk and protein, and other $\mathrm{N}_{\mathrm{r}}$ losses, which could create an additional source of uncertainty.

\subsubsection{Manure and urine}

Prescribed manure (including urine) is input at a constant annual rate $\left(\alpha_{\text {applied }}(m)\right)\left(\mathrm{g} \mathrm{m}^{-2} \mathrm{~s}^{-1}\right)$ into the manure nitrogen pools depending on latitude and longitude. It is assumed that a fraction $\left(f_{\mathrm{u}}=0.5\right)$ of nitrogen excreted is urine, with the remaining $50 \%$ excreted as fecal matter (Gusman and Mariño, 1999). In practice the fraction of nitrogen excreted as urine is highly variable and depends on the type of animal feed and other parameters (Jarvis et al., 1989). The excreted urine is directly added to the TAN pool $\left(\mathrm{g} \mathrm{N} \mathrm{m}^{-2}\right)$. This is consistent with urea forming the dominant component of urine $\mathrm{N}$ and the subsequent rapid conversion of urea to ammoniacal form (Bristow et al., 1992). Feces are composed of matter with varying carbon to nitrogen ratios that take different times to decompose depending on how easily they can be digested by microbes. Excreted feces are assumed to form three different pools $\left(\mathrm{g} \mathrm{m}^{-2}\right)$ depending on their rate of mineralization (e.g., Gusman and Mariño, 1999): (1) we assume a fraction $f_{\text {un }}=5 \%$ is excreted as unavailable nitrogen $\left(\mathrm{N}_{\text {unavailable }}\right)$, the lignin component of manure where the nitrogen remains immobilized by bacteria (C: $\mathrm{N}$ ratio $>25: 1)$; (2) a fraction $f_{\mathrm{r}}=45 \%$ goes to the resistant pool $\left(\mathrm{N}_{\text {resistant }}\right)$, which forms the cellulose component of manure $(\mathrm{C}: \mathrm{N}$ ratio ca. 15:1), which forms TAN relatively slowly; (3) and a fraction $f_{\mathrm{a}}=50 \%$ goes to the available pool $\left(\mathrm{N}_{\text {available }}\right)$ that is readily available to form TAN $\left(\mathrm{N}_{\text {available }}\right)$. In reality the fractions within each of these broadly defined pools will be dependent on the type of animal and the type of feed. 
The equations governing the three manure pools (see Fig. 1) are

$$
\begin{aligned}
\mathrm{dN}_{\text {available }} / \mathrm{d} t & =f_{\mathrm{a}} \times \alpha_{\text {applied }}(m)-K_{\mathrm{a}} \times \mathrm{N}_{\text {available }} \\
& -k_{\mathrm{m}} \times \mathrm{N}_{\text {available }}, \\
\mathrm{dN}_{\text {resistant }} / \mathrm{d} t & =f_{\mathrm{r}} \times \alpha_{\text {applied }}(m)-K_{\mathrm{r}} \times \mathrm{N}_{\text {resistant }} \\
& -k_{\mathrm{m}} \times \mathrm{N}_{\text {resistant }}, \\
\mathrm{dN}_{\text {unavailable }} / \mathrm{d} t & =f_{\text {un }} \times \alpha_{\text {applied }}(m)-k_{\mathrm{m}} \times \mathrm{N}_{\text {unavailable }},
\end{aligned}
$$

where $\alpha_{\text {applied }}(m)$ is the amount of manure applied $\left(\mathrm{g} \mathrm{m}^{-2} \mathrm{~s}^{-1}\right) ; f_{\mathrm{a}}, f_{\mathrm{r}}$ and $f_{\text {un }}$ are the fractions of manure applied to each pool; and $K_{\mathrm{a}}$ and $K_{\mathrm{r}}\left(\mathrm{s}^{-1}\right)$ are temperaturedependent mineralization rates of these manure pools and into soil nitrogen pools. The decay constants, $K_{\mathrm{a}}$ and $K_{\mathrm{r}}$, are measured as the fast and slow decomposition rates for biosolids added to various soils and incubated at $25^{\circ} \mathrm{C}$ (Gilmour et al., 2003), where a two-component decay model accurately fits approximately $73 \%$ of the samples incubated. The decay timescales for manure in the available and resistant pools at $25^{\circ} \mathrm{C}$ are 48 and 667 days, respectively. The temperature dependence of the decay constants is derived from a fit of temperature-dependent mineralization rates (see Appendix A) (Vigil and Kissel, 1995) corresponding to a $Q_{10}$ value of 3.66. To prevent the manure pools from building up over long timescales we assume that manure is incorporated into soils with a time constant of 365 days with a mechanical rate constant $k_{\mathrm{m}}$. This timescale is consistent with the base bioturbation rate of $1 \mathrm{~cm}^{2} \mathrm{yr}^{-1}$ assumed in Koven et al. (2013) and a typical length scale of $1 \mathrm{~cm}$. The sensitivity of the subsequent nitrogen pathways to this timescale is small (Sect. 3.4). Note that nitrogen in the $\mathrm{N}_{\text {unavailable }}$ pool does not mineralize and is thus only incorporated into soil organic matter on the timescale determined by $k_{\mathrm{m}}$. We assume that nitrogen prior to conversion to TAN comprises a range of insoluble organic compounds that do not wash away or otherwise volatilize.

\subsubsection{Synthetic fertilizer}

Synthetic fertilizer nitrogen is added to the $\mathrm{N}_{\text {fertilizer }}$ pool $\left(\mathrm{g} \mathrm{N} \mathrm{m}^{-2}\right)$ (Fig. 1) at a rate $\left(\alpha_{\text {applied }}(t)(f)\right)\left(\mathrm{g} \mathrm{N} \mathrm{m}^{-2} \mathrm{~s}^{-1}\right)$ that depends on geography and time. The amount of nitrogen within the synthetic fertilizer pool is subsequently released into the TAN pool at the rate $k_{\mathrm{f}}\left(\mathrm{s}^{-1}\right)$ :

$\mathrm{dN}_{\text {fertilizer }} / \mathrm{d} t=\alpha_{\text {applied }}(f)-k_{\mathrm{f}} \times \mathrm{N}_{\text {fertilizer }}$.

Here we assume all synthetic fertilizer is urea. We set the decay timescale of urea fertilizer to be 2.4 days, consistent with the decay rate measured in Agehara and Warncke (2005) for temperatures from 15 to $20^{\circ} \mathrm{C}$. In a series of experiments Agehara and Warncke (2005) show that $75 \%$ of the urea hydrolyzes in a week at temperatures from 10 to $25^{\circ} \mathrm{C}$ without a significant dependence on temperature especially for temperatures above 15 to $20^{\circ} \mathrm{C}$.
The timing for synthetic fertilizer application is determined internally within the CLM4.5 crop model (Levis et al., 2012) as the spring planting date for corn. Note, however, that except for the determining the timing of fertilizer application, the crop model is not used. We use the planting date for corn since the CLM4.5 crop model only specifically includes corn, soybean and temperate cereals and the planting date for corn lies between the earlier planting date for temperate cereal crops and the later planting of soy. The date for fertilizer application is determined for each grid point location using the surface temperature-based criteria developed by Levis et al. (2012) for simulating the planting date of corn: the 10-day running mean temperature, 10-day running mean daily minimum temperature and growing degree days must all surpass fixed threshold values $(283.15$ and $279.15 \mathrm{~K}$ and 50 days, respectively) before planting can take place. Fertilizer application dates can have a large influence on the seasonality of the emissions (e.g., see Paulot et al., 2014) and the subsequent flows of $\mathrm{N}_{\mathrm{r}}$ (Sect. 3.4). Future applications will assume more complete algorithms for fertilizing the spectrum of crops, as well as multiple fertilizer applications and double cropping. A global accounting of fertilization practices and application techniques (e.g., fertilizer injection) nevertheless remains a considerable source of uncertainty in a global simulation of the $\mathrm{NH}_{3}$ emissions from agriculture.

\subsubsection{Total ammoniacal nitrogen (TAN)}

We consider two TAN pools $\left(\mathrm{g} \mathrm{N} \mathrm{m}^{-2}\right.$ ), one for the nitrogen produced from synthetic fertilizer $\mathrm{N}_{\text {TAN }}(f)$ the other for nitrogen from manure $\mathrm{N}_{\text {TAN }}(m)$. The budget for the manure and synthetic fertilizer TAN pools respectively is given by

$$
\begin{aligned}
\mathrm{N}_{\mathrm{TAN}}(m) / \mathrm{d} t & =f_{\mathrm{u}} \times \alpha_{\text {applied }}(m)+K_{\mathrm{r}} \times \mathrm{N}_{\text {resistant }}+K_{\mathrm{a}} \\
& \times \mathrm{N}_{\text {available }}-F_{\text {run }}(m)-K_{D}^{\mathrm{NH}_{4}} \\
& \times \mathrm{N}_{\mathrm{TAN}}(m)-F_{\mathrm{NH}_{3}}(m)-F_{\mathrm{NO}_{3}}(m), \\
\mathrm{N}_{\mathrm{TAN}}(f) / \mathrm{d} t & =k_{\mathrm{f}} \times \mathrm{N}_{\text {fertilizer }}-F_{\text {run }}(f)-K_{D}^{\mathrm{NH}_{4}} \\
& \times \mathrm{N}_{\mathrm{TAN}}(f)-F_{\mathrm{NH}_{3}}(f)-F_{\mathrm{NO}_{3}}(f) .
\end{aligned}
$$

Here $F_{\text {run }}(m / f)\left(\mathrm{g} \mathrm{N} \mathrm{m}^{-2} \mathrm{~s}^{-1}\right)$ is the loss of nitrogen by runoff from the manure or synthetic fertilizer TAN pool; $K_{D}^{\mathrm{NH}_{4}}\left(\mathrm{~s}^{-1}\right)$ is the loss rate of nitrogen to the soil nitrogen pools; $F_{\mathrm{NH}_{3}}(m)$ and $F_{\mathrm{NH}_{3}}(f)\left(\mathrm{g} \mathrm{N} \mathrm{m}^{-2} \mathrm{~s}^{-1}\right)$ are the $\mathrm{NH}_{3}$ emissions from the manure and fertilizer TAN pools, respectively, to the atmosphere; and $F_{\mathrm{NO}_{3}}(m)$ and $F_{\mathrm{NO}_{3}}(f)$ $\left(\mathrm{g} \mathrm{N} \mathrm{m}^{-2} \mathrm{~s}^{-1}\right)$ are the loss of nitrogen through nitrification from the manure and synthetic fertilizer TAN pools. The formulation of each of these terms is given below. Inputs into $\mathrm{N}_{\text {TAN }}(m)$ pool are from the fraction $\left(f_{\mathrm{u}}\right)$ of applied manure as urine $\left(\alpha_{\text {applied }}(m)\right)$, and from the decomposition of the nitrogen within the available and resistant manure pools. Input into the $\mathrm{N}_{\mathrm{TAN}}(f)$ pool is from the synthetic fertilizer pool. 


\subsubsection{Runoff of nitrogen to rivers}

The immediate runoff of fertilizer and manure nitrogen to rivers from the manure and fertilizer TAN pools is derived from the runoff rate of water $(R)\left(\mathrm{m} \mathrm{s}^{-1}\right)$ in the CLM multiplied by concentration of nitrogen in the TAN water pool:

$F_{\text {run }}(m / f)=R \times \frac{\mathrm{N}_{\mathrm{TAN}}(m / f)}{N_{\text {water }}(m / f)}$.

The value of $R$ is calculated within the CLM and is a function of precipitation, evaporation, drainage and soil saturation. The amount of water within the TAN pool $\left(N_{\text {water }}(m / f)\right)(m)$ is needed to convert $\mathrm{N}_{\mathrm{TAN}}\left(\mathrm{g} \mathrm{N} \mathrm{m}^{-2}\right)$ to a concentration $\left(\mathrm{g} \mathrm{N} \mathrm{m}^{-3}\right)$. An expression for $N_{\text {water }}(m / f)$ is given in Sect. 2.2.9. It should be emphasized that this is the immediate runoff of manure and synthetic fertilizer nitrogen from the TAN pools. Subsequent loss of nitrogen derived from manure and synthetic fertilizer application occurs following the nitrogen transfer to the soil pools, but is not tracked in these simulations. Additional hydrological losses will also occur following the deposition of $\mathrm{NH}_{3}$ volatilized to the atmosphere. These losses are also not tracked in the current simulation.

Initially, we attempted to use the runoff parameterization based on the global Nutrient Export from Watersheds 2 (NEWS 2) model (Mayorga et al., 2010), where runoff is also parameterized in terms of $R$. However, the amount of nitrogen that runs off in NEWS 2 is represented in terms of the annual nitrogen initially applied to the land and thus is not directly related to the amount of nitrogen in the TAN pool.

\subsubsection{Diffusion through soil}

Nitrogen is assumed to diffuse from the TAN pool to the soil pools. Génermont and Cellier (1997) represent the diffusion coefficient of ammonium through soils as dependent on soil water content, soil porosity, temperature and an empirical diffusion coefficient of ammonium in free water (see Appendix A). For example, assuming a temperature of $21^{\circ} \mathrm{C}$, a soil porosity of 0.5 and a soil water content of 0.2 the resulting diffusion coefficient is approximately $0.03 \mathrm{~cm}^{2} \mathrm{day}^{-1}$, in reasonable agreement with measurements in Canter et al. (1996). Here we assume a typical length scale of $1.0 \mathrm{~cm}$ to convert the diffusion rate to a timescale. The resulting diffusion of ammoniacal nitrogen is added to preexisting nitrogen pools in CLM4.5 and is not further tracked.

\subsubsection{Flux of ammonia to the atmosphere}

The flux of $\mathrm{NH}_{3}\left(F_{\mathrm{NH}_{3}}, \mathrm{~g} \mathrm{~m}^{-2} \mathrm{~s}^{-1}\right)$ to the atmosphere is calculated from the difference between the $\mathrm{NH}_{3}$ concentration at the surface $\left(\mathrm{NH}_{3}(\mathrm{~g}), \mathrm{g} \mathrm{m}^{-3}\right)$ of the TAN pool and the freeatmosphere $\mathrm{NH}_{3}$ concentration $\left(\chi_{\mathrm{a}}, \mathrm{g} \mathrm{m}^{-3}\right)$ divided by the aerodynamic $\left(R_{\mathrm{a}}\right)$ and boundary layer $\left(R_{\mathrm{b}}\right)$ resistances $(\mathrm{Ne}-$ mitz et al., 2000; Loubet et al., 2009, Sutton et al., 2013).

$F_{\mathrm{NH}_{3}}=\frac{\mathrm{NH}_{3}(\mathrm{~g})-\chi_{\mathrm{a}}}{R_{\mathrm{a}}(z)+R_{\mathrm{b}}}$

The calculation of $\mathrm{NH}_{3}(\mathrm{~g})$ is given below. For compatibility with the $\mathrm{NH}_{3}$ emission parameterization we compute average values of $R_{\mathrm{a}}$ and $R_{\mathrm{b}}$ over each CLM soil column, which may contain several PFTs. We specify $\chi_{\mathrm{a}}$ to be $0.3 \mu \mathrm{g} \mathrm{m}^{-3}$, representative of concentrations over low-activity agricultural sites (Zbieranowski and Aherne, 2012). Continental $\mathrm{NH}_{3}$ concentrations between 0.1 and $10 \mu \mathrm{g} \mathrm{m}^{-3}$ have been reported by Zbieranowski and Aherne (2012) and Heald et al. (2012). A concentration of $0.3 \mu \mathrm{g} \mathrm{m}^{-3}$ is intermediate between concentrations at low to moderate pollution sites as diagnosed in GEOS-chem (Warner et al., 2016). The sensitivity to this parameter is small as $\mathrm{NH}_{3}(\mathrm{~g})$ is usually very large (Sect. 3.4). While Eq. (8) allows for negative emissions $\left(\mathrm{NH}_{3}(\mathrm{~g})<\chi_{\mathrm{a}}\right)$ or deposition of atmospheric $\mathrm{NH}_{3}$ onto the soil we disallow negative emissions in the current simulations. In future studies the atmospheric concentration of $\mathrm{NH}_{3}$ will be calculated interactively by coupling the FAN model to the atmospheric chemistry component of the CESM (CAMchem), thus allowing the dynamics of the $\mathrm{NH}_{3}$ exchange between the soil, the atmosphere and vegetation to be captured (e.g., Sutton et al., 2013).

A large fraction of the $\mathrm{NH}_{3}$ emitted to the atmosphere is assumed captured by vegetation. The amount emitted to the atmosphere is given by

$F_{\mathrm{NH}_{3} \text { atm }}(m / f)=\left(1-f_{\text {capture }}\right) \times F_{\mathrm{NH}_{3}}(m / f)$,

where $f_{\text {capture }}$ is set to 0.6 . Plant recapture of emitted $\mathrm{NH}_{3}$ is often reported to be as high as $75 \%$ (Harper et al., 2000; Nemitz et al., 2000; Walker et al., 2006; Denmead et al., 2008; Bash et al., 2010). Using seabird nitrogen on different substrates (rock, sand, soil and vegetation) inside a chamber, Riddick (2012) found $\mathrm{NH}_{3}$ recapture to be $0 \%$ on rock, $32 \%$ on sand, $59 \%$ on soil and $73 \%$ on vegetation. We set $f_{\text {capture }}$ to 0.6 as a mid-point between the value for soil (when the crops are planted) and when crops are fully grown (Wilson et al., 2004). Bouwman et al. (1997) also used canopy capture to estimate emissions with the captured fraction ranging from 0.8 in tropical rainforests to 0.5 in other forests to 0.2 for all other vegetation types, including grasslands and shrubs. Bouwman et al. (1997) omitted canopy capture over arable lands and intensively used grasslands. Overall, the deposition of $\mathrm{NH}_{3}$ onto the canopy (or even the soil surface) is poorly constrained (e.g., see Erisman and Draaijers, 1995) and often ignored in model simulations. In reality canopy capture is not constant but depends on surface characteristics and boundary layer meteorology. Variations in canopy capture will induce temporal and regional variations in $\mathrm{NH}_{3}$ emissions. Explicitly including canopy capture fraction allows a differentiation between biogeochemical pathways in future studies. In the future, when the model is fully coupled with the atmospheric $\mathrm{NH}_{3}$ cycle a compensation point approach would be 
desirable for calculating the net $\mathrm{NH}_{3}$ emissions, but this is outside the scope of the present study.

It is assumed that the nitrogen in the TAN pool is in equilibrium between $\mathrm{NH}_{3}(\mathrm{~g})\left(\mathrm{g} \mathrm{m}^{-3}\right), \mathrm{NH}_{3}(\mathrm{aq})\left(\mathrm{g} \mathrm{N} \mathrm{m}^{-3}\right)$ and $\mathrm{NH}_{4}^{+}(\mathrm{aq})\left(\mathrm{g} \mathrm{N} \mathrm{m}^{-3}\right)$. The equilibrium that governs the speciation of these species is determined by the Henry's law coefficient $\left(K_{\mathrm{H}}\right)$, where $K_{\mathrm{H}}$ is a measure of the solubility of $\mathrm{NH}_{3}$ in water, and the disassociation constant of $\mathrm{NH}_{4}^{+}$in water $\left(K_{\mathrm{NH}_{4}}\right)\left(\mathrm{mol} \mathrm{L}^{-1}\right)$ (e.g., Sutton et al., 1994):

$\mathrm{NH}_{3}(\mathrm{~g})+\mathrm{H}_{2} \mathrm{O} \stackrel{K_{\mathrm{H}}}{\longleftrightarrow} \mathrm{NH}_{3}(\mathrm{aq})$,

$\mathrm{NH}_{4}^{+}(\mathrm{aq}) \stackrel{K_{\mathrm{NH}_{4}}}{\longleftrightarrow} \mathrm{NH}_{3}(\mathrm{aq})+\mathrm{H}^{+}$.

Combining these two expressions $\mathrm{NH}_{3}(\mathrm{~g})$ can be expressed as a function of the total TAN (e.g., Pinder et al., 2004, although note their different units for $K_{\mathrm{H}}$ and $K_{\mathrm{NH}_{4}}$ ):

$\mathrm{NH}_{3}(\mathrm{~g})(m / f)=\frac{\mathrm{N}_{\mathrm{TAN}}(m / f) / N_{\text {water }}(m / f)}{1+K_{\mathrm{H}}+K_{\mathrm{H}}\left[\mathrm{H}^{+}\right] / K_{\mathrm{NH}_{4}}}$,

where $\left[\mathrm{H}^{+}\right]$is the hydrogen ion concentration in $\mathrm{mol} \mathrm{L}^{-1}$. Both $K_{\mathrm{H}}$ and $K_{\mathrm{NH}_{4}}$ are temperature-dependent. As temperature and $\mathrm{pH}$ increase the concentration of $\mathrm{NH}_{3}(\mathrm{~g})$ increases. The $\mathrm{pH}$ of the solution depends on the type of soil, the exposure of the manure to air, and the type of fertilizer used and may change with the aging of the manure or synthetic fertilizer. In Eghball et al. (2000) the majority of the reported measurements of $\mathrm{pH}$ for beef cattle feedlot manure are between 7 and 8 , although in one case a $\mathrm{pH}$ of 8.8 was measured. The recommended $\mathrm{pH}$ for various crops ranges from approximately 5.8 to 7.0 depending on the crop (e.g., http://onondaga.cce.cornell.edu/resources/ soil-ph-for-field-crops). For now we simply set the $\mathrm{pH}$ of the solution to 7 for both the synthetic fertilizer and manure TAN pools. Sensitivity to $\mathrm{pH}$ is explored in Sect. 3.4.

\subsubsection{Conversion of TAN to $\mathrm{NO}_{3}^{-}$}

The flux of $\mathrm{N}_{\mathrm{r}}$ from the TAN pool to $\mathrm{NO}_{3}^{-}$by nitrification $\left(F_{\mathrm{NO}_{3}^{-}}, \mathrm{g} \mathrm{m}^{-2} \mathrm{~s}^{-1}\right)$ was adapted from Stange and Neue (2009) for the gross nitrification rates in response to fertilization of a surface with manure or synthetic fertilizer. In particular, Stange and Neue (2009) fit measured gross nitrification rates to an expression using a maximal nitrification rate, $r_{\max }\left(\mu \mathrm{g} \mathrm{N} \mathrm{kg}{ }^{-1} \mathrm{~h}^{-1}\right)$, modified by a soil temperature response function $(f(T))$ and a soil moisture response function $(f(M))$ (Stange and Neue, 2009). However, since $r_{\max }$ is fit from their experimental data, the dependence of the nitrification rate on the ammonium concentration is not explicitly included in the formulation of Stange and Neue (2009). We have remedied this by setting the maximum nitrification rate $\left(r_{\max }\right)$ in the formulation of (Stange and Neue, 2009) to be consistent with the formulation in Parton et al. (2001):

$F_{\mathrm{NO}_{3}}(m / f)=\frac{2 \cdot r_{\max } N_{\text {water }}(m / f) \mathrm{NH}_{3}(\mathrm{~g})(m / f) K_{\mathrm{H}}\left[\mathrm{H}^{+}\right] / K_{\mathrm{NH}_{4}}}{\frac{1}{\Sigma\left(T_{\mathrm{g}}\right)}+\frac{1}{\Pi(M)}}$, where $\Sigma\left(T_{\mathrm{g}}\right)$ and $\Pi(M)$ are functions of soil temperature and moisture and the ammonium concentration is assumed to be in equilibrium with the other forms of ammoniacal nitrogen and is thus expressed in terms of $\mathrm{pH}, K_{\mathrm{H}}$ and $K_{\mathrm{NH}_{4}}$ and $\mathrm{NH}_{3}(\mathrm{~g})(\mathrm{m} / \mathrm{f})$ and $r_{\max }$ is equal to $1.16 \times 10^{-} 6 \mathrm{~s}^{-1}$.

\subsubsection{Nitrate}

The rate of change of the nitrate pool is given by

$\mathrm{dN}_{\mathrm{NO}_{3}}(m / f) / \mathrm{d} t=F_{\mathrm{NO}_{3}}(m / f)-K_{D}^{\mathrm{NO}_{3}} \mathrm{~N}_{\mathrm{NO}_{3}}(m / f)$.

The source of nitrate ions is nitrification from the TAN pool. Nitrate is lost to the soil nitrate pool through diffusion. Nitrate leaching is not explicitly taken into account in the current model as the diffusion of nitrate into the soil pools occurs very rapidly. The loss of nitrate through runoff and leaching can, however, occur within the CLM, but is not tracked in the current simulations. Nitrate ions diffuse significantly faster than the $\mathrm{NH}_{4}^{+}$ions because they are not subject to immobilization by negatively charged soil particles (Mitsch and Gosselink, 2007). Diffusion rates used in this study are derived from the same formulation as assumed for the diffusion of ammonium (e.g., see Jury et al., 1983) with a different base diffusion rate. The summary of measurements given in Canter et al. (1996), where both the diffusion of ammonium and nitrate were measured in the same soil types and wetness, suggest the base diffusion rate of $\mathrm{NO}_{3}^{-}$is approximately 13 times faster than that of ammonium.

\subsubsection{TAN and manure water pools}

The evolution of the TAN manure and synthetic fertilizer water pools depends on the water added during manure or synthetic fertilizer application and the subsequent evolution of the water in the pools. The equations for the manure and synthetic fertilizer water are

$$
\begin{aligned}
\mathrm{d} N_{\text {water }}(m) / \mathrm{d} t & =s_{\mathrm{w}}(m) \times \alpha_{\text {applied }}(m)-k_{\text {relax }} \\
& \times\left(N_{\text {water }}(m)-M_{\text {water }}\right), \\
\mathrm{d} N_{\text {water }}(f) / \mathrm{d} t & =S_{\mathrm{w}}(f) \times \alpha_{\text {applied }}(f)-k_{\text {relax }} \\
& \times\left(N_{\text {water }}(f)-M_{\text {water }}\right) .
\end{aligned}
$$

These equations include a source of water $\left(s_{\mathrm{W}}(m)\right.$ or $\left.S_{\mathrm{W}}(f)\right)$ added as a fraction of the synthetic fertilizer or manure applied and a relaxation term $\left(k_{\text {relax }}, \mathrm{s}^{-1}\right)$ to the soil water $\left(M_{\text {water }}(m)\right)$ calculated in the CLM for the top $5 \mathrm{~cm}$ of soil. $M_{\text {water }}$ explicitly takes into account the modification of the water pool due to rainfall, evaporation and the diffusion of water in the soil layers. We assume the TAN pool equilibrates with water within the top $5 \mathrm{~cm}$ of the soil with a rate of 3 days $^{-1}$. The solution is insensitive to this parameter within the ranges examined of 1 to 10 days $^{-1}$ (Sect. 3.4). The water content of manure applied to fields depends on the animal, its feedstock and on agricultural practices. Here we assume cattle manure is added as a slurry with a dry fraction of 
$74.2 \mathrm{~g} \mathrm{~kg}^{-1}$ and a nitrogen content of $1.6 \mathrm{~g} \mathrm{~kg}^{-1}$, resulting in $5.7 \times 10^{-4} \mathrm{~m}$ water applied per gram of manure nitrogen applied (Sommer and Hutchings, 2001). In the case of synthetic fertilizer we assume urea is added as a liquid spread, where water added is calculated from the temperature-dependent solubility of urea in water (UNIDO and IFDC, 1998).

\subsection{Model spin-up and forcing}

Two different types of model simulations were conducted using CLM4.5: a present-day control simulation (1990-2004) and a historical simulation (1850-2000). The resolution used in these simulations is $1.9^{\circ}$ latitude by $2.5^{\circ}$ longitude.

\subsubsection{Present-day control simulation}

This simulation uses the manure and synthetic fertilizer input as given in Potter et al. (2010). Forcing at the atmospheric boundary is set to the Qian et al. (2006) reanalysis for solar input, precipitation, temperature, wind and specific humidity. The simulation is run for 15 model years (1990-2004), with the last 10 years of the simulation used for analysis. The spin-up period allows for the more decomposition resistant $\mathrm{N}$ pools to approach a steady state with respect to the loss from mechanical incorporation into the soil.

\subsubsection{Historical simulation}

The historical simulation uses transient forcing conditions (accounting for changes in atmospheric $\mathrm{CO}_{2}$, nitrogen deposition, aerosol deposition and land use change forcings) and the Qian et al. (2006) atmospheric forcing data set. Quality 6-hourly meteorological data sets for the period prior to 1948 do not exist. Therefore from 1850 to 1973 CLM4.5 is driven by recycled meteorological data, using meteorological data from the 1948-1973 time period. During this time long-term temperature changes were small: the statistically significant long-term changes in temperature (outside of natural variability) occur after 1973. After 1973 the meteorological data are not recycled but are valid for the year applied.

The temporal distribution of manure and synthetic fertilizer application from 1850-2000 is specified by applying the temporal distribution of Holland et al. (2005) to the base values as calculated in Potter et al. (2010). Due to the lack of detailed information on the geography of historical manure and synthetic fertilizer we use the scaled spatial distribution from Potter et al. (2010). We assume manure production has changed from $26.3 \mathrm{Tg} \mathrm{Nyr}^{-1}$ in 1860 to $125 \mathrm{Tg} \mathrm{Nyr}^{-1}$ in 2000 (Holland et al., 2005; Potter et al., 2010), but we acknowledge that these temporal changes are uncertain. Synthetic fertilizer was first used in the 1920s, with use increasing to $62 \mathrm{Tg} \mathrm{N} \mathrm{yr}^{-1}$ in 2000 .

\section{Results}

\subsection{Model evaluation}

To evaluate model output, measurements of the percentage of applied nitrogen that was emitted as $\mathrm{NH}_{3}\left(P_{\mathrm{V}}\right)$ from the literature were compared against corresponding model predictions. The model predictions are obtained from the presentday control simulation. The percent-volatilized $\mathrm{NH}_{3}$ was used as a metric because it can be compared across time, irrespective of the absolute amount of nitrogen applied to the surface. To be able to compare emissions to published measurements, we require field studies with published data on nitrogen excretion rates, $\mathrm{NH}_{3}$ emissions, ground temperature, location, and date of measurement. Given all of these requirements we found that only a small selection of publications had sufficient data.

For the manure emissions, 44 measurements in a range of climates (temperatures from 1.4 to $28^{\circ} \mathrm{C}$ ) and a range of livestock management methods (commercial beef cattle feed yard, dairy cows grazing on ryegrass, beef cattle grazing on ryegrass and dairy cattle grazing on pasture land) were used (Supplement Table S1). Each $P_{\mathrm{v}}$ reported by the measurement campaign was compared against the $P_{\mathrm{v}}$ at the corresponding grid cell in the model. For the synthetic fertilizer scenario, 10 measurements in a range of latitudes $\left(43^{\circ} \mathrm{S}\right.$ to $50^{\circ} \mathrm{N}$ ) over a range of land use surfaces (pasture, sown crops, turf and forest) were used (Table S2). Each total annual $P_{\mathrm{v}}$ reported by the measurement campaign was compared against the annual $P_{\mathrm{v}}$ of the corresponding grid cell.

\subsubsection{Nitrogen volatilized as $\mathrm{NH}_{3}$ from manure}

There is a general increase in $P_{\mathrm{v}}$ with temperature, in both the model and measurements (Fig. 2). However, temperature is not the only factor in determining $\mathrm{NH}_{3}$ emissions, where wind speed, water availability and below ground soil properties can also effect $\mathrm{NH}_{3}$ emission. This is particularly demonstrated by the measurements of Todd et al. (2007) at temperatures less than $5^{\circ} \mathrm{C}$ where the measured emissions are higher than those predicted at higher temperatures (e.g., Bussink, 1992). It is also worth noting that the model predicts the emissions of Todd et al. (2007) at lower temperatures with relative success.

The agreement between measured and modeled $P_{\mathrm{v}}$ from manure appears reasonable, with an $R^{2}$ of 0.76 that is significant at the $99.9 \%$ confidence level. On closer inspection, the model appears to agree best with measurements made on grassland and differs considerably with measurements made by both campaigns for beef cattle feedlots in Texas, where beef cattle feedlots are commercial operations to prepare livestock for slaughter and comprise thousands of animals contained in a pen. This is perhaps not surprising, as the parameterization developed here explicitly represents 


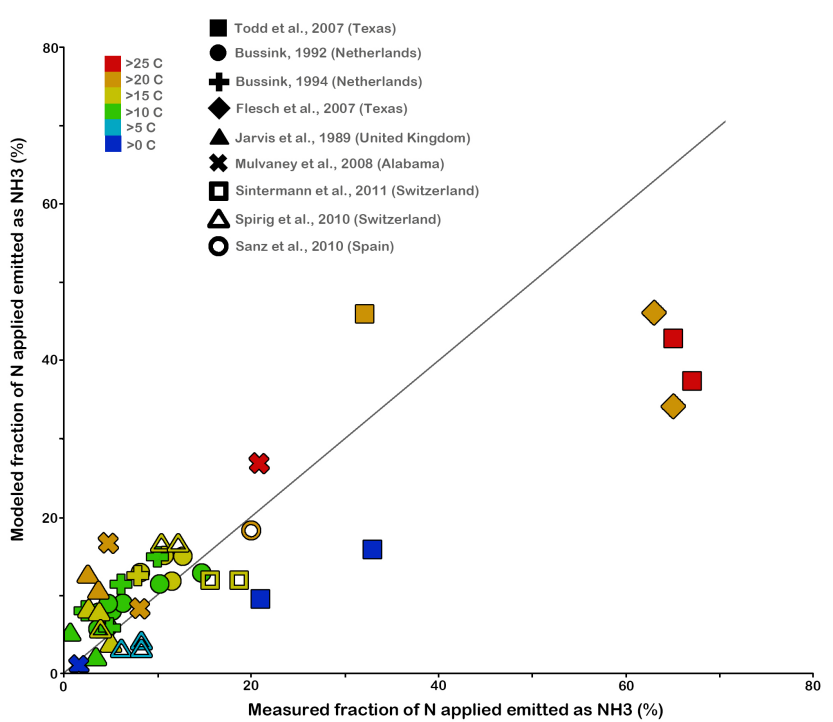

Figure 2. Comparison of model to measurements for percentage of nitrogen lost as $\mathrm{NH}_{3}$ emissions from manure for a range of studies (see Table S1). Symbol color indicates temperature at which the emissions occurred; shape gives the study.

emissions from manure spreading as opposed to the more managed conditions in feedlots.

\subsubsection{Nitrogen volatilized as $\mathrm{NH}_{3}$ from synthetic fertilizer}

The comparison between measured and modeled annual average $P_{\mathrm{v}}$ from synthetic fertilizer applied to a range of land use types is weak, with an $R^{2}$ of 0.2 that is significant at the $90 \%$ confidence level (Fig. 3). The lowest emissions in the model and measurements tend to be associated with the higher latitudes of both hemispheres. There does not appear to be any noticeable bias with land use type where the model estimates are both higher and lower than measured values of $P_{\mathrm{v}}$ for surfaces covered in turf, pasture land and crops. The fact that the $R^{2}$ for the synthetic fertilizer measurements is lower than the $R^{2}$ of the manure measurements is potentially caused by differences between actual farming practices and model assumptions.

\subsubsection{Nitrogen runoff}

In this study we simulate the direct nitrogen runoff from the manure and synthetic fertilizer TAN pools, but do not track the resulting nitrogen flows. These flows are tracked, however, in Nevison et al. (2016), where the nitrogen runoff from manure and synthetic fertilizer pools is routed into the river transport model (RTM) (Dai and Trenberth, 2002; Branstetter and Erickson III, 2003) within the CESM. Nevison et al. (2016) assume denitrification occurs within the simulated rivers at a rate inversely proportional to the river depth (amounting to approximately $30 \%$ of the nitrogen in-

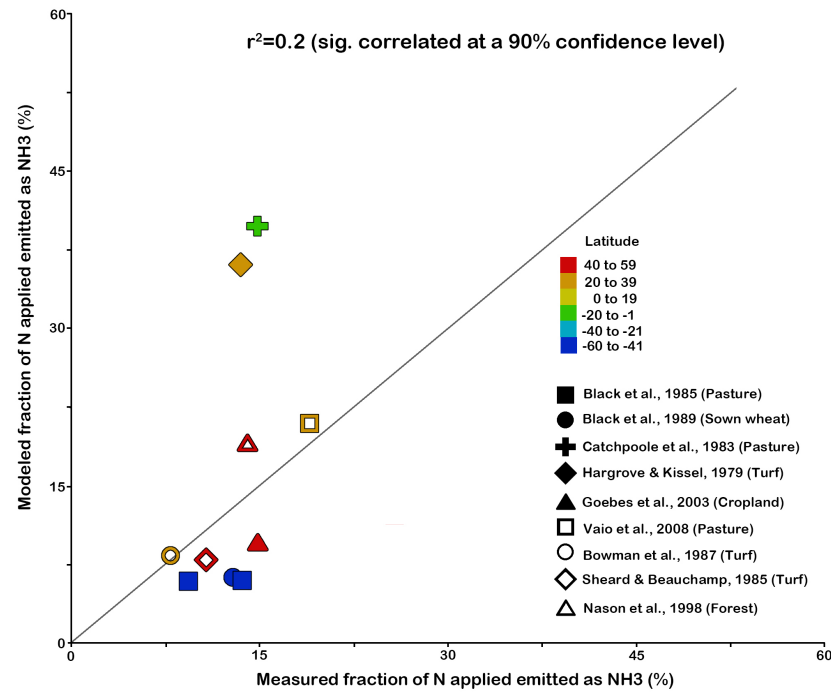

Figure 3. Comparison of model to measurements for percentage of nitrogen lost as $\mathrm{NH}_{3}$ emissions from synthetic fertilizer (see Table S2) for a range of studies. Symbol color gives the latitude at which the emissions occurred; symbol shape gives the study and type of synthetic fertilizer application.

puts on average) and compare the simulated dissolved inorganic nitrogen (DIN) export at the river mouths against measurements (Van Drecht et al., 2003) following Global NEWS (Mayorga et al., 2010). The simulated DIN export is nearly unbiased for six identified rivers with high human impact: the Columbia, Danube, Mississippi, Rhine, Saint Lawrence and Uruguay. Explicit comparisons against the Mississippi River show that the amplitude and seasonality of the simulated $\mathrm{N}_{\mathrm{r}}$ runoff is in reasonable agreement with the measurements. While the comparison in Nevison et al. (2016) gives confidence that the runoff is reasonably simulated, the complications in simulating river runoff preclude tight model constraints.

\subsection{Global nitrogen pathways: present day}

\subsubsection{Geography of nitrogen inputs}

Global maps of nitrogen input from synthetic fertilizer and manure application during the present-day simulation are given in Potter et al. (2010) and are not repeated here. Heavy synthetic fertilizer use generally occurs in the upper Midwest of the US (mostly east of $100^{\circ} \mathrm{W}$ and north of $40^{\circ} \mathrm{N}$ ), western Europe (mostly west of $20^{\circ} \mathrm{E}$ and north of $40^{\circ} \mathrm{N}$ ), the northern part of India and much of northeastern and north central China. High manure usage coincides with the areas of heavy synthetic fertilizer use but is more widespread extending across much of eastern South America from 20-40 $\mathrm{S}$ and across Africa at approximately $10^{\circ} \mathrm{N}$. 

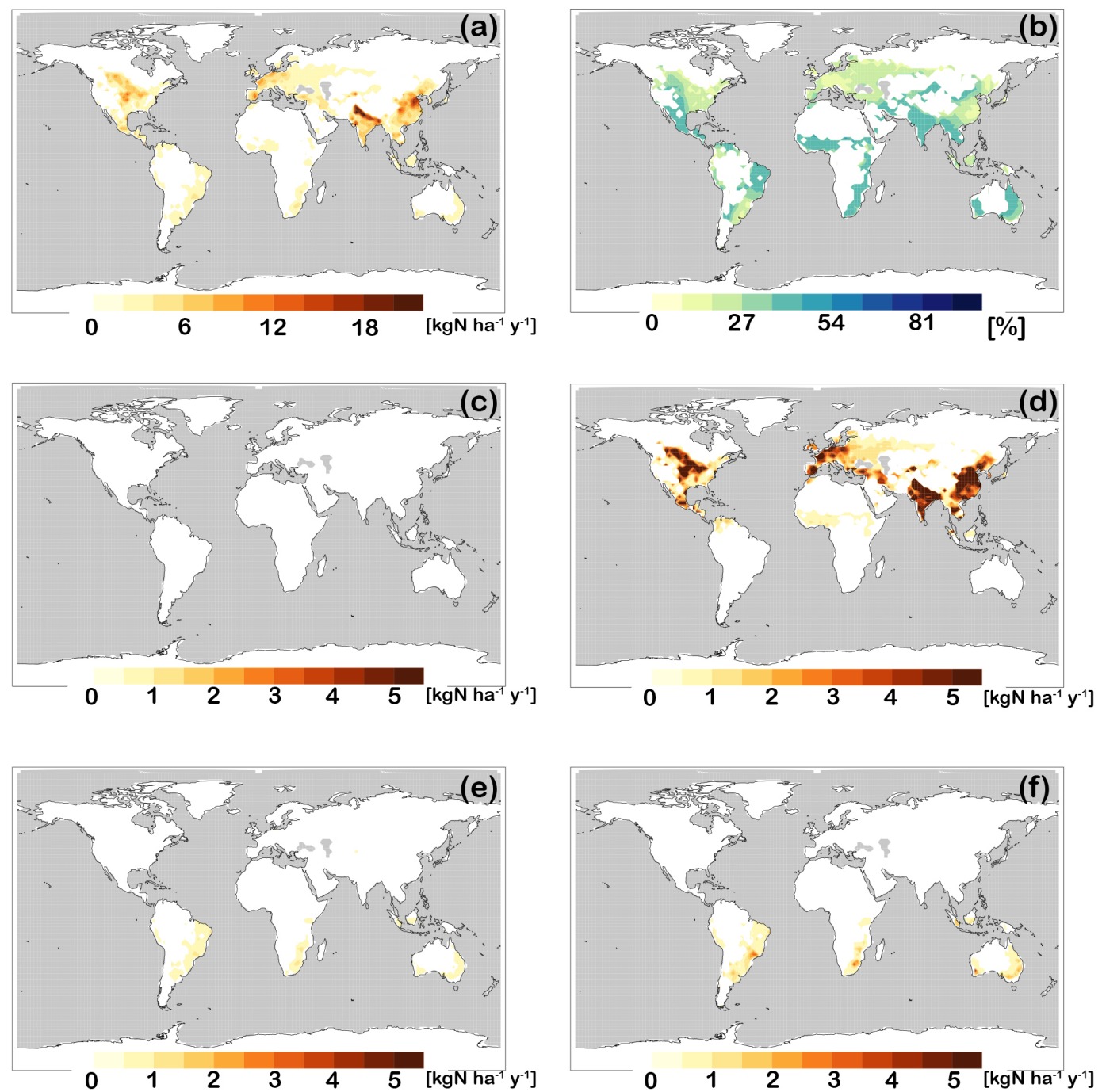

Figure 4. Simulated $\mathrm{NH}_{3}$ emissions from synthetic fertilizer application from 1995 to 2004 for the present-day control simulation. Simulated emissions ( $\mathrm{kg} \mathrm{N} \mathrm{ha}^{-1} \mathrm{yr}^{-1}$ ) as (a) an annual average, (c) January-February-March average, (d) April-May-June average, (e) July-AugustSeptember average, and (f) October-November-December average. Panel (b) shows simulated emissions as a percent of annual synthetic fertilizer application.

\subsubsection{Geography of nitrogen losses}

There are strong geographical differences in the loss pathways of nitrogen following manure or synthetic fertilizer application. The importance of the various loss pathways from the TAN pool (the amount nitrogen volatilized as $\mathrm{NH}_{3}$, runoff, nitrified or diffused directly into the soil, Figs. 4-8) is dependent on temperature, precipitation and soil moisture. In hot, arid climates, the percentage volatilized is high (Figs. 4 and 5). For example, regions of high $\mathrm{NH}_{3}$ volatilization of applied manure $\mathrm{N}_{\mathrm{r}}$ approach $50 \%$ across the southwest US and Mexico, eastern South America, central and southern Africa, parts of Australia, and across southern Asia from India to Turkey (Fig. 5). The absolute highest emissions of $\mathrm{NH}_{3}$ from applied synthetic fertilizer and from applied ma- nure approach $20 \mathrm{~kg} \mathrm{Nha}^{-1} \mathrm{yr}^{-1}$ over hot regions with high applications, e.g., the Indian subcontinent and parts of China (Figs. 4 and 5). Ammonia emissions from manure are more broadly distributed globally than those of synthetic fertilizer with high $\mathrm{NH}_{3}$ emissions not only over the synthetic fertilizer hotspots, characterized by heavy application of both synthetic fertilizer and manure but also over southeastern South America and central Africa. For the most part, the largest synthetic fertilizer $\mathrm{NH}_{3}$ emissions occur during April-June, reflecting the single fertilization date used in this study as calculated in the CLM for corn. While Paulot et al. (2014) also show the maximum synthetic fertilizer emissions generally occur from April-June, they obtain relatively higher emissions than simulated here during the other seasons. This is likely due to differences in the assumed timing of applied 

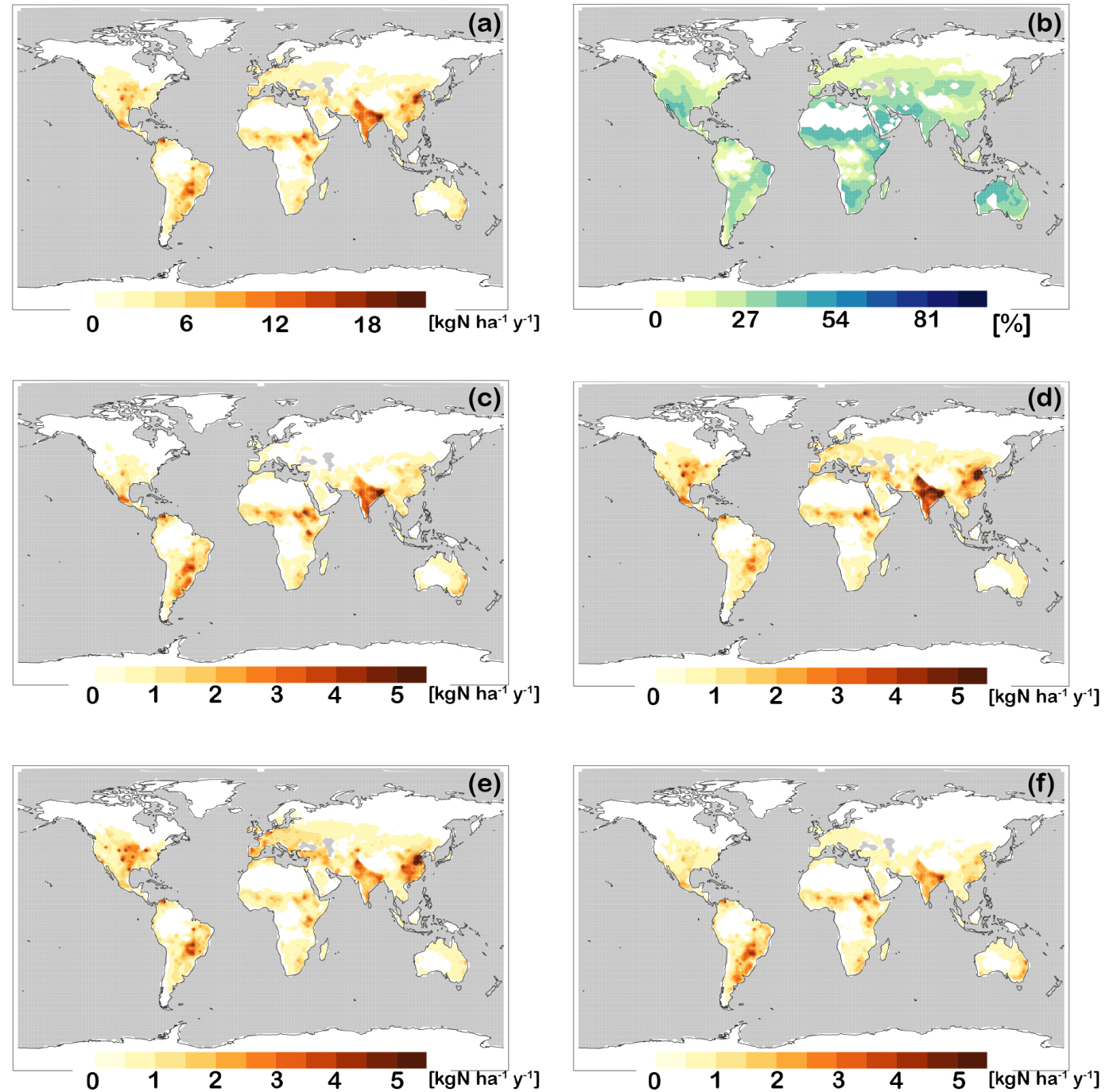

Figure 5. As in Fig. 4 but for manure application.

synthetic fertilizer: Paulot et al. (2014) consider three different synthetic fertilizer applications for each crop as well as a wide variety of crops. The seasonal emission distribution of $\mathrm{NH}_{3}$ emissions from manure is broader than that of synthetic fertilizer but with maximum emissions usually occurring in April-June or July-September. The simulated geographical and seasonal $\mathrm{NH}_{3}$ emission distribution from manure is in broad agreement with Paulot et al. (2014).

Runoff of $\mathrm{N}_{\mathrm{r}}$ from applied synthetic fertilizer and manure TAN pools, as well as nitrification and diffusion into the soil, depends on precipitation and soil moisture. High manure and synthetic fertilizer $\mathrm{N}_{\mathrm{r}}$ runoff from the TAN pools (see Fig. 6) occurs particularly across parts of China, Europe (particularly the northern parts) and the east central US. The global hotspot for simulated $\mathrm{N}_{\mathrm{r}}$ runoff from the TAN pools is China, where runoff approaches $20 \mathrm{~kg} \mathrm{~N} \mathrm{ha}^{-1} \mathrm{yr}^{-1}$ for nitrogen applied as either manure or synthetic fertilizer. In general the importance of runoff as a nitrogen loss pathway becomes more important in the wetter and cooler regions. In contrast, over India and Spain the agricultural nitrogen input is high, but the runoff is relatively low. In these regions with high temperatures (and dry conditions) $\mathrm{NH}_{3}$ volatilization is the preferred pathway for nitrogen losses from the TAN pool.

The percent of the TAN pool nitrified or diffused directly into the soil (see Figs. 7 and 8) also tends to be largest in wetter and cooler regions. The amount of nitrogen nitrified has an optimal temperature of $28^{\circ} \mathrm{C}$ and tends to occur more rapidly under moist conditions; the diffusion of nitrogen into the soil is also promoted under wet conditions.

\subsubsection{Regional and global accounting of nitrogen losses}

As nitrogen cascades through the environment it can be emitted as $\mathrm{NH}_{3}$ or runoff or leached at many different stages. Here we only examine the losses directly from manure or fertilizer TAN pools. Globally, the direct loss of applied ni- 

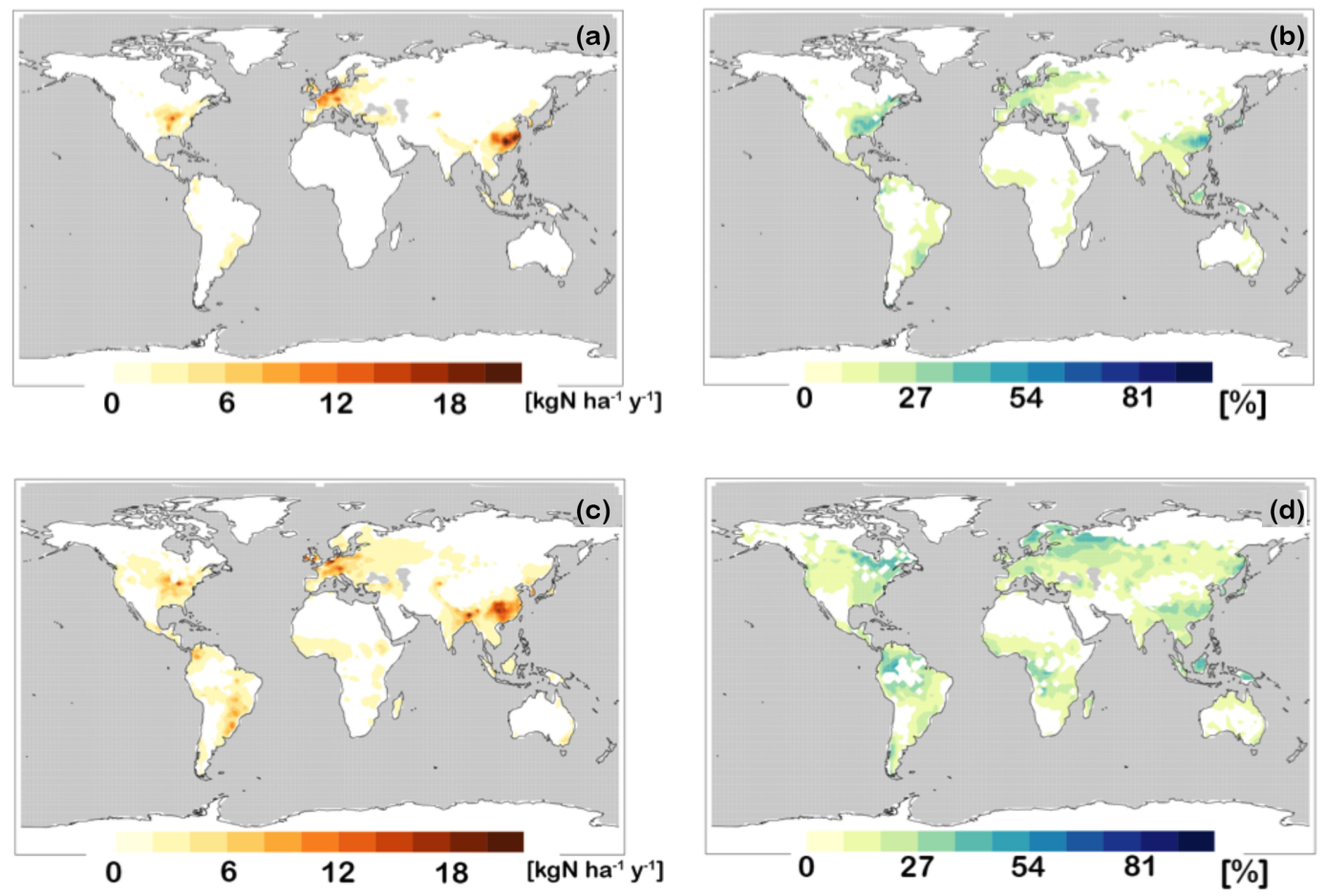

Figure 6. Simulated runoff of $\mathrm{N}_{\mathrm{r}}$ from synthetic fertilizer and manure TAN pools for the present-day (1995-2004) control simulation. Simulated runoff $\left(\mathrm{kg} \mathrm{N} \mathrm{ha}^{-1} \mathrm{yr}^{-1}\right)$ as an annual average for (a) synthetic fertilizer, (c) manure. Simulated as (b) percent of annual synthetic fertilizer application, (d) percent of annual manure application.

trogen to the atmosphere as $\mathrm{NH}_{3}$ is similar for manure and synthetic fertilizer (17\% for manure, $19 \%$ for synthetic fertilizer; see Fig. 9). Our global estimates of the percent of manure and synthetic fertilizer volatilized as $\mathrm{NH}_{3}$ are similar to Bouwman et al. (2002) and Beusen et al. (2008), although our estimate for synthetic fertilizer volatilization as $\mathrm{NH}_{3}$ is somewhat high. Bouwman et al. (2002) estimate 19-29\% of applied manure and 10-19\% of applied synthetic fertilizer volatilizes as $\mathrm{NH}_{3}$; Beusen et al. (2008) conclude $15-23 \%$ of applied manure is lost as $\mathrm{NH}_{3}$ (including losses from housing and storage, grazing and spreading) and $10-18 \%$ of applied synthetic fertilizer is lost.

We calculate the global direct runoff from manure or fertilizer TAN pools as $8 \%$ for manure $\mathrm{N}_{\mathrm{r}}$ and $9 \%$ for synthetic fertilizer (Fig. 9). Bouwman et al. (2013) find that $23 \%$ of deposited $\mathrm{N}_{\mathrm{r}}$ (comprised of synthetic fertilizer, manure and atmospheric nitrogen deposition) runs off, higher than our estimate. However, our estimate only includes the direct runoff from the TAN pool. Additional nitrogen is lost downstream from the TAN pool due to runoff and leaching from the soil nitrogen pools or following $\mathrm{NH}_{3}$ emission and re-deposition.

Our simulations assume a large fraction of emitted nitrogen is captured by the canopy, where canopy capture accounts for $25.5 \%$ of manure losses and $30 \%$ of synthetic fertilizer losses (Fig. 9). The nitrogen captured by the canopy may have a number of fates. First, Sparks (2009) posits that foliar nitrogen uptake could more readily influence plant growth than uptake from soils since it is a direct addition of $\mathrm{N}$ to plant metabolism. As such it would decrease plant demand on soil uptake and thus conserve the soil nitrogen reservoirs. Secondly, nitrogen uptake by the plants, even if not directly used in plant metabolism, may redeposit onto the surface with litterfall. Finally, it may be emitted back to the atmosphere from plants. The latter process can be represented through a compensation point model between the atmosphere, the ground and stomata (e.g., Massad et al., 2010). A full accounting of this requires the simulation to be fully coupled with the atmosphere and soil chemistry and biogeochemistry, which is beyond the scope of the present study.

In the case of synthetic fertilizer the direct diffusion of TAN $\mathrm{N}_{\mathrm{r}}$ into the soil pool (22\%) is larger than nitrification $(17 \%)$; for manure it is just the opposite: the nitrification $(29 \%)$ is larger than the direct diffusion (14\%) (Fig. 9). In practice, as simulated here, this makes little difference as the diffusion of nitrate into the soil pool occurs very rapidly, an order of magnitude faster than the diffusion of nitrogen from the TAN pool. Thus, $\mathrm{NO}_{3}^{-}$is directly incorporated into the soil nitrate pool without any subsequent loss. It should also be noted that a small percentage of manure is mechanically stirred into the soil organic nitrogen pools. Accounting for the $\mathrm{N}_{\mathrm{r}}$ diffused from the TAN pool into the soil pools, and assuming the $\mathrm{NH}_{3}$ emissions captured by the canopy, as well 
as the ammonium nitrified to $\mathrm{NO}_{3}^{-}$that also ends up in the soil pools, we find that globally $75 \%$ of manure nitrogen and $71 \%$ of synthetic fertilizer nitrogen ends up in the soil nitrogen or soil organic nitrogen pools. Emitted $\mathrm{NH}_{3}$ may also end up in the soil nitrogen pools downstream of the emissions. Of course, once in these soil pools, there may be subsequent losses of nitrogen due to runoff and leaching or emissions, but these are not calculated in this initial study.

The global percentages given above change appreciably when examined over subsets of countries (Fig. 10). For example, over all developed countries the percentage of emissions of manure and synthetic fertilizer TAN as $\mathrm{NH}_{3}(13 \%)$ is substantially smaller than for developing countries (21\%). These differences can be largely explained by the fact that developing countries tend to be located in warmer climates than developed countries (e.g., see Bouwman et al., 2002). Bouwman (2002) calculated $\mathrm{NH}_{3}$ emission factors for manure of 21 and $26 \%$ for developed and industrialized countries, respectively and for synthetic fertilizer of 7 and $18 \%$, respectively.

In our simulations 16 and $9 \%$ of applied agricultural nitrogen is emitted as $\mathrm{NH}_{3}$ in the US and the European Union, respectively. The direct runoff of nitrogen accounts for 9 and $14 \%$ of the losses of agricultural nitrogen in the US and the European Union, respectively. Nitrogen runoff is favored in the cooler moister climate of Europe. However, note the large contrast between India and China, where for India $\mathrm{NH}_{3}$ emissions are $27 \%$ of the applied $\mathrm{N}_{\mathrm{r}}$ with very little runoff, whereas for China the runoff and emissions are approximately equal (13 and $10 \%$, respectively).

\subsubsection{Comparison to other emissions inventories}

Figure 11 gives a comparison of manure and synthetic fertilizer $\mathrm{NH}_{3}$ emissions from the FAN process model for the year 2000 to various emission inventories. These inventories rely on emission factors depending on animal husbandry, types of synthetic fertilizer usage and other details of agricultural practices. Only the $\mathrm{NH}_{3}$ emission inventory of Huang et al. (2012) for China and that of Paulot et al. (2014) explicitly account for temperature to modify their emission factors; the inventory of Paulot et al. (2014) also uses wind speed to modify the emission factors. The inventories of Paulot et al. (2014) for 2005-2008, Beusen et al. (2008) for 2000, and EDGAR v4.2 (European Commission JRC and PBL, 2011) for 2005-2008 are global inventories. The EDGAR inventory does not strictly separate the $\mathrm{NH}_{3}$ emissions into those from manure and synthetic fertilizer, so we simply show the overall $\mathrm{NH}_{3}$ emissions from both manure and synthetic fertilizer. Over the US we also give an estimate for synthetic fertilizer $\mathrm{NH}_{3}$ from 1995 (Goebes et al., 2003) and for $\mathrm{NH}_{3}$ emissions from animal agricultural operations (US EPA, 2004). Over the China region, emission estimates are from Huang et al. (2012) for 2006 and Streets et al. (2003) for 2000. Over Europe, results using the Greenhouse Gas and Air Pol- lution Interactions and Synergies (GAINS) model are given (Klimont and Brink, 2004) as reported in Paulot et al. (2014).

Globally all inventories give approximately the same overall $\mathrm{NH}_{3}$ emissions of $30-35 \mathrm{Tg} \mathrm{N} \mathrm{yr}^{-1}$. The global apportionment of emissions between manure and synthetic fertilizer in this study is in approximately the ratio of $2: 1$, roughly consistent with that of Paulot et al. (2014) and Beusen et al. (2008). In this study the overall $\mathrm{NH}_{3}$ emissions are high over the US compared to the other inventories: the manure $\mathrm{NH}_{3}$ emissions are close to the estimate of other inventories, while the synthetic fertilizer emissions are higher. The European and Chinese $\mathrm{NH}_{3}$ emissions estimated in this study are on the low side of the other inventories. Over Europe the current parameterization underestimates the manure emissions compared to the other studies while the synthetic fertilizer emissions are somewhat high. The EDGAR emission estimate is somewhat higher than the other estimates over Europe, although this may depend on exactly what is assumed for the boundary of the European region. Over China our synthetic fertilizer emissions are similar to those of Huang et al. (2012), but we underestimate the manure $\mathrm{NH}_{3}$ emissions compared to the other inventories. Of the three regions examined all inventories suggest the Chinese emissions are highest.

\subsubsection{Site-specific simulated pathways}

The hourly time series of the fate of applied nitrogen from manure and synthetic fertilizer at a single site better illustrates the relationship between the different nitrogen flow pathways and the local meteorology (Fig. 12). The large fluctuations in the $\mathrm{NH}_{3}$ emissions and the resultant implications for atmospheric chemistry also demonstrate the desirability of emissions that respond on hourly timescales to meteorological conditions. The site shown in Fig. 12 is near the Texas panhandle. It experiences several large rain events and surface temperatures ranging from 0 to $18^{\circ} \mathrm{C}$ over a period of about 2 months during the spring season examined. The response of the $\mathrm{NH}_{3}$ emissions to the diurnal temperature range is clearly evident. Near the beginning of the examined period the nitrogen losses of manure TAN due to $\mathrm{NH}_{3}$ volatilization are initially small, comparable with the diffusive loss to the soil pools and somewhat less than the loss due to nitrification. The loss by nitrification and the diffusion from the TAN manure pool remain roughly constant throughout the period examined, although both processes show some response to precipitation. Note in particular that the diffusive loss reaches a maximum near 21 May, presumably caused by the increased water content in the soil due to the prior rain event. With the rise in temperatures towards the end of the period, the $\mathrm{NH}_{3}$ emission loss of manure $\mathrm{N}_{\mathrm{r}}$ becomes the dominant loss pathway and the TAN manure pool decreases. Closer inspection suggests, however, that the large increase in the $\mathrm{NH}_{3}$ emissions towards the end of the period cannot solely be attributed to temperature but must also 

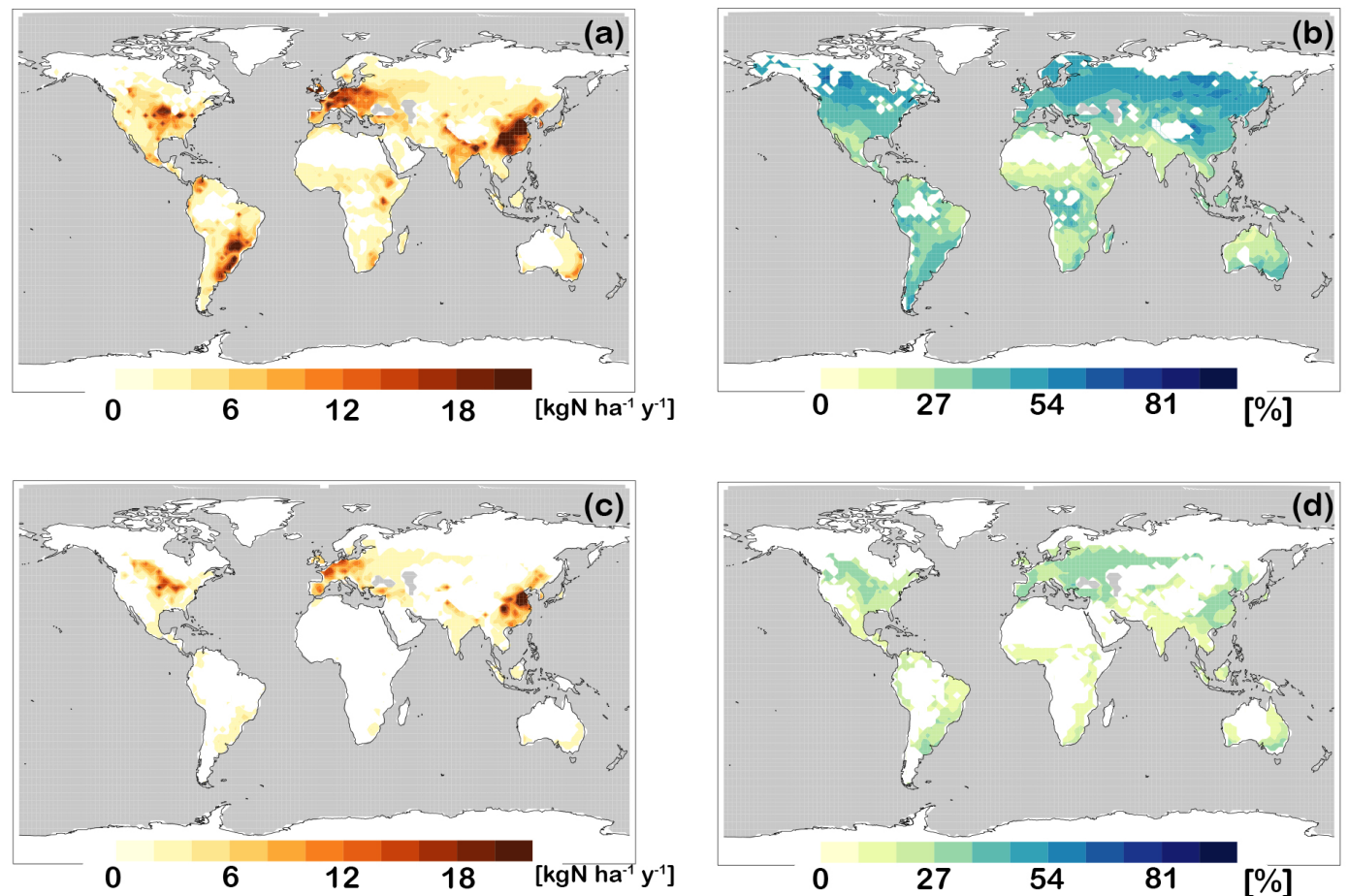

Figure 7. As in Fig. 6 but for simulated nitrification.
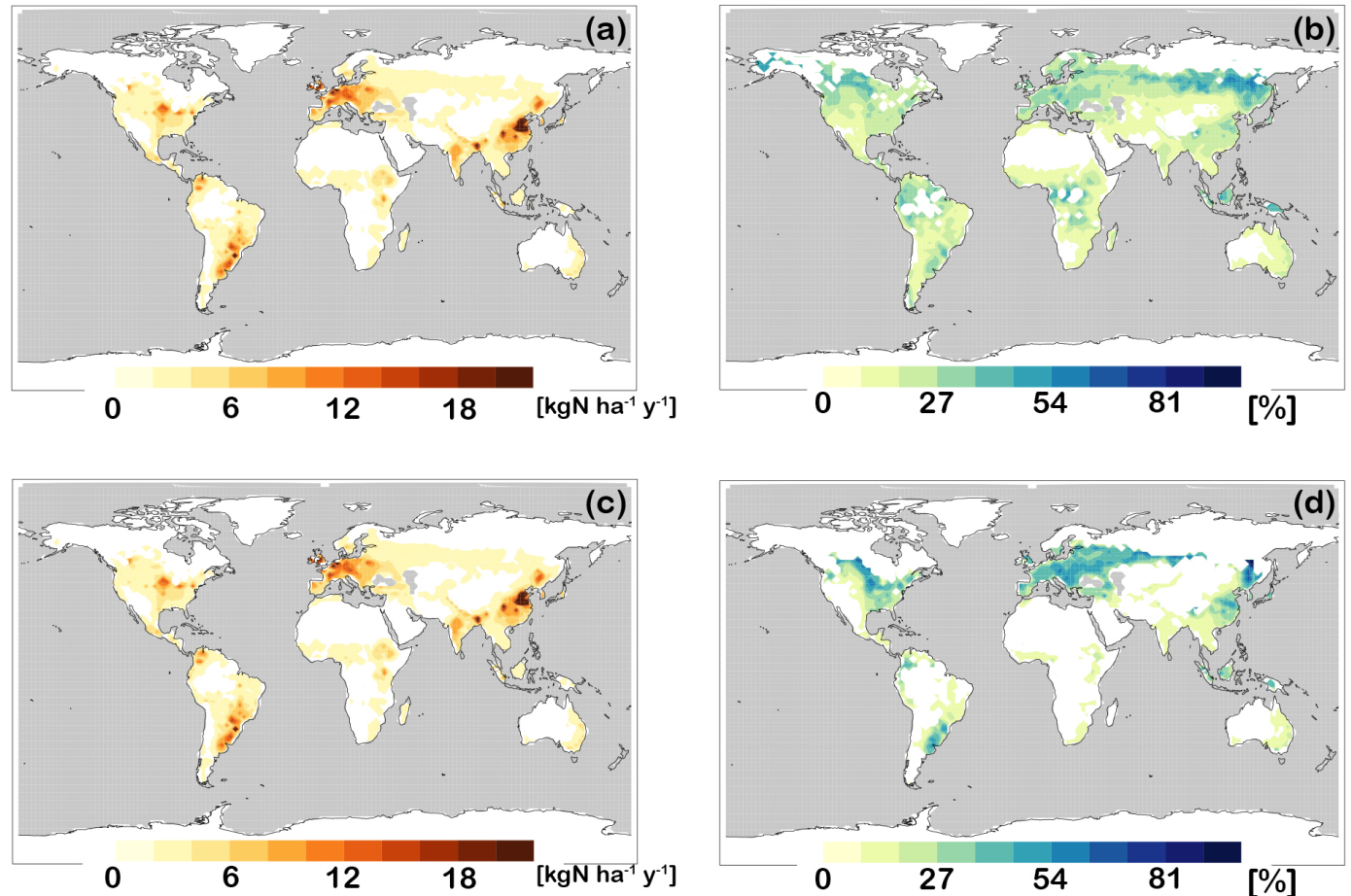

Figure 8. As in Fig. 6 but for flux of TAN nitrogen to the soil. 


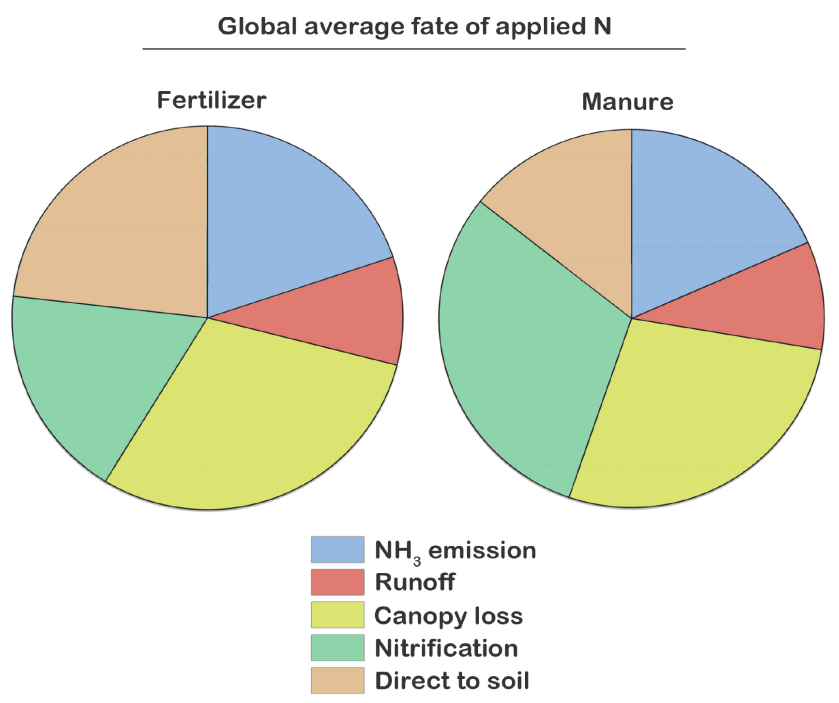

Figure 9. Global fate of TAN Nr applied as synthetic fertilizer (a) or as manure (b). $\mathrm{NH}_{3}$ emissions are split between those to the atmosphere and those captured by the canopy.

be attributed to decreased water in the TAN pool as the soil dries. The latter process increases the concentration of nitrogen species within the TAN pool. The TAN manure pool is punctuated by sharp declines, associated with precipitation and increased runoff (Fig. 12c). Synthetic fertilizer TAN responds similarly during this period but is clearly impacted by the temporal application of synthetic fertilizer. The decrease in the synthetic fertilizer TAN pool occurs on a timescale of approximately a week, consistent with the timescale used in the MASAGE_NH3 model (Paulot et al., 2014).

\subsection{Global nitrogen pathways: historical}

Historical nitrogen pathways are simulated since 1850 in a simulation with changing climate and changing application amounts. These simulations do not include changing agricultural practices, for example changes in animal housing and storage, changes in animal diet and explicit changes in land use. All of these changes may substantially alter the nitrogen loss pathways. Thus the results must be treated with caution.

The nitrogen produced as manure increases in the historical simulation from $21 \mathrm{Tg} \mathrm{N} \mathrm{yr}^{-1}$ in 1850 to $125 \mathrm{Tg} \mathrm{N} \mathrm{yr}^{-1}$ in 2000 (Fig. 13). In 1900 we estimate that $37 \mathrm{Tg} \mathrm{N} \mathrm{yr}^{1}$ of manure is produced, similar to the Bouwman et al. (2013) estimate of $35 \mathrm{Tg} \mathrm{N} \mathrm{yr}^{-1}$. Emissions of $\mathrm{NH}_{3}$ from applied manure increase from approximately $3 \mathrm{Tg} \mathrm{N} \mathrm{yr}^{-1}$ in 1850 ( $14.3 \%$ of the manure produced) to $22 \mathrm{Tg} \mathrm{Nyr}^{-1}$ in 2000 ( $17.6 \%$ of the applied manure). On the other hand, the percentage of manure nitrogen that is nitrified decreases from 33 to $27 \%$ since the preindustrial period. Note that the year 2000 emissions in the historical simulation differ slightly from the year 2000 emissions reported in the present-day control simulation, as the latter consists of the average emissions from 1995 to 2004.

Synthetic fertilizer nitrogen application has increased dramatically since the $1960 \mathrm{~s}$, with an estimated $62 \mathrm{Tg} \mathrm{N} \mathrm{yr}^{-1}$ applied as synthetic fertilizer in 2000 . We estimate that the volatilization of synthetic fertilizer as $\mathrm{NH}_{3}$ is $12 \mathrm{Tg} \mathrm{N} \mathrm{yr}^{-1}$ in 2000 (19\% of that applied). The percent of synthetic fertilizer nitrogen volatized to the atmosphere as $\mathrm{NH}_{3}$ in 1920 was $8 \%$. On the other hand, the percentage of synthetic fertilizer that is lost through runoff decreased since the preindustrial period by $8 \%$. These changes can be explained by the fact the runoff of synthetic fertilizer can act to completely drain the TAN synthetic fertilizer pool when the application rate is small.

In part the historical emission increases in $\mathrm{NH}_{3}$ can also be explained by changes in climate. The globally averaged temperature has warmed by approximately $1{ }^{\circ} \mathrm{C}$ since the preindustrial period. In a sensitivity experiment the temperature was artificially increased by $1{ }^{\circ} \mathrm{C}$ in the rate equations governing the nitrogen pathways following manure and synthetic fertilizer application. Under current manure and synthetic fertilizer application rates we find that globally an additional $1 \mathrm{Tg} \mathrm{NH}_{3}$ is emitted from the manure and synthetic fertilizer pools per degree of warming. The resulting manure emissions increase by $4 \%$ and the synthetic fertilizer emissions by $3 \%$ per degree of warming.

\subsection{Sensitivity tests}

We have conducted a large number of sensitivity tests to evaluate the effect of changes in individual model parameters on $\mathrm{NH}_{3}$ emissions. The various parameters may covary, of course, with nonlinear impacts on the $\mathrm{NH}_{3}$ emissions; however, we have not attempted to evaluate these effects. The sensitivity tests for manure are given in Table 1, and those for synthetic fertilizer in Table 2 . The sensitivity tests are labeled with a number denoting the sensitivity parameter perturbed and a letter denoting whether the test is with respect to manure emissions $(m)$ or synthetic fertilizer emissions $(f)$. In each case we give the percent change in $\mathrm{NH}_{3}$ emissions due to the parameter change and the relative emission change with respect to the relative parameter change (the sensitivity). Rationale for the assumed parameter bounds is given in the Supplement.

Except for changes in the canopy capture parameter $(\mathrm{EX} 8 \mathrm{~m} / \mathrm{f}, \mathrm{EX} 9 \mathrm{~m} / \mathrm{f})$ and changes in the timing or composition of manure or synthetic fertilizer inputs (EX18m, EX18f, EX19f, EX20f), changes in the sensitivity parameters directly change the nitrogen cycling within the TAN pool (as described below). For the most part the synthetic fertilizer and manure TAN pools respond similarly to the parameter changes. Note also that, except for EX18m, where the amount of nitrogen input into the TAN pools is reduced, the total input and loss of nitrogen from the TAN pools remain the same for all sensitivity experiments. In general, the sen- 
Table 1. Manure sensitivity tests.

\begin{tabular}{|c|c|c|c|c|c|c|c|c|c|}
\hline Exper. ${ }^{1}$ & Parameter $^{2}$ & Value $^{3}$ & $\mathrm{NH}_{3}^{4}$ & Run $^{5}$ & Soil $^{6}$ & Nitrif. ${ }^{7}$ & Canopy $^{8}$ & $\Delta \mathrm{NH}_{3}^{9} \%$ & Sens. ${ }^{10} \% / \%$ \\
\hline Control $^{11}$ & & & 19.5 & 10.2 & 15.2 & 32.3 & 29.2 & & \\
\hline EX1m & $k_{\mathrm{m}}$ & $100 d^{-1}$ & 16.6 & 9.1 & 13.6 & 41.8 & 24.8 & -15 & 0.20 \\
\hline $\mathrm{EX} 2 \mathrm{~m}$ & $k_{\mathrm{m}}$ & $750 d^{-1}$ & 20.8 & 10.7 & 16 & 25.9 & 31.2 & +7 & 0.06 \\
\hline $\mathrm{EX} 3 \mathrm{~m}$ & $k_{\text {relax }}$ & $1 \mathrm{~d}^{-1}$ & 19.5 & 10.2 & 15.3 & 32.2 & 29.2 & 0 & 0.0 \\
\hline $\mathrm{EX} 4 \mathrm{~m}$ & $k_{\text {relax }}$ & $10 \mathrm{~d}^{-1}$ & 19.4 & 10.3 & 15.2 & 32.4 & 29.1 & +1 & 0.0 \\
\hline EX5m & $\mathrm{pH}$ & 6 & 8.0 & 16.6 & 23.9 & 45.8 & 12.0 & -59 & 4.1 \\
\hline EX6m & $\mathrm{pH}$ & 8 & 29.6 & 3.7 & 5.1 & 23.5 & 44.4 & +52 & 3.6 \\
\hline $\mathrm{EX} 7 \mathrm{~m}$ & $\mathrm{pH}$ & data set ${ }^{12}$ & 15.0 & 13.8 & 18.4 & 36.8 & 22.5 & -23 & \\
\hline EX8m & $f_{\text {capture }}$ & 0.4 & 29.2 & 10.2 & 15.2 & 32.3 & 19.5 & +50 & -1.3 \\
\hline EX9m & $f_{\text {capture }}$ & 0.8 & 9.7 & 10.2 & 15.2 & 32.3 & 38.9 & -50 & -2.2 \\
\hline EX10m & $\chi_{\mathrm{a}}$ & $0.1 \mu \mathrm{g} \mathrm{m}^{-3}$ & 20.0 & 9.9 & 14.7 & 31.8 & 30.0 & +3 & -0.04 \\
\hline EX11m & $\chi_{\mathrm{a}}$ & $1 \mu \mathrm{g} \mathrm{m}^{-3}$ & 18.2 & 11.1 & 16.4 & 33.5 & 27.3 & -7 & -0.03 \\
\hline $\mathrm{EX} 12 \mathrm{~m}$ & $\mathrm{H}_{2} \mathrm{O}$ depth & $10 \mathrm{~cm}$ & 16.0 & 7.7 & 20.7 & 37.9 & 24.1 & -18 & -0.18 \\
\hline EX13m & $\mathrm{H}_{2} \mathrm{O}$ depth & $2 \mathrm{~cm}$ & 23.1 & 13.4 & 8.2 & 27.1 & 34.6 & +18 & -0.31 \\
\hline EX14m & $K_{D}$ & $\times 0.5$ & 20.7 & 11.6 & 9.4 & 33.8 & 31.0 & +6 & -0.12 \\
\hline EX15m & $K_{D}$ & $\times 2.0$ & 17.8 & 8.5 & 22.9 & 30.4 & 26.8 & -9 & -0.09 \\
\hline EX16m & $r_{\max }$ & $\times 0.5$ & 20.7 & 11.0 & 16.7 & 27.0 & 31.1 & +6 & -0.12 \\
\hline EX17m & $r_{\max }$ & $\times 2.0$ & 17.5 & 9.0 & 13.0 & 40.5 & 26.3 & -10 & -0.10 \\
\hline EX18m & manure comp ${ }^{13}$ & & 15.4 & 8.4 & 12.5 & 23.8 & 23.1 & -21 & \\
\hline
\end{tabular}

${ }^{1}$ Control experiment. ${ }^{2}$ Parameter changed from default values. ${ }^{3}$ New parameter value. ${ }^{4} \mathrm{NH}_{3}$ emissions $\left(\mathrm{Tg} \mathrm{N} \mathrm{yr}^{-1}\right) .{ }^{5} \mathrm{Runoff}\left(\mathrm{Tg} \mathrm{N}_{\mathrm{yr}}{ }^{-1}\right) .{ }^{6} \mathrm{Diffusion}_{\text {to soil }}$ $\left(\mathrm{Tg} \mathrm{N} \mathrm{yr}^{-1}\right) \cdot{ }^{7}$ Nitrification $\left(\mathrm{Tg} \mathrm{N} \mathrm{yr}^{-1}\right) .{ }^{8}$ Canopy capture $\left(\mathrm{Tg} \mathrm{N} \mathrm{yr}^{-1}\right) \cdot{ }^{9}$ Percent change in $\mathrm{NH}_{3}$ emissions due to parameter change $(\%) .{ }^{10}$ Percent change in $\mathrm{NH}_{3}$ emissions per $\%$ change in parameter value ${ }^{11}$ Control simulation. ${ }^{12} \mathrm{Soil} \mathrm{pH}$ from the ISRIC-WISE data set (Batjes, 2005). ${ }^{13}$ Change in manure composition to urine $41 \%$, available $21 \%$, unavailable $25 \%$, and resistant $13 \%$.

Table 2. Fertilizer sensitivity tests.

\begin{tabular}{|c|c|c|c|c|c|c|c|c|c|}
\hline Exper. ${ }^{1}$ & Parameter $^{2}$ & Value $^{3}$ & $\mathrm{NH}^{4}$ & Run $^{5}$ & Soil $^{6}$ & Nitrif. $^{7}$ & Canopy ${ }^{8}$ & $\Delta \mathrm{NH}_{3}^{9} \%$ & Sens. ${ }^{10} \% / \%$ \\
\hline Control $^{11}$ & & & 10.9 & 5.3 & 12.3 & 9.8 & 16.3 & & \\
\hline EX3f & $k_{\text {relax }}$ & $1 \mathrm{~d}^{-1}$ & 11.3 & 5.6 & 11.6 & 9.0 & 17.0 & +4 & -0.06 \\
\hline EX4f & $k_{\text {relax }}$ & $10 d^{-1}$ & 10.1 & 4.7 & 13.7 & 10.9 & 15.1 & -7 & -0.03 \\
\hline EX5f & $\mathrm{pH}$ & 6 & 4.4 & 8.5 & 17.7 & 17.5 & 6.5 & -60 & +4.2 \\
\hline EX6f & $\mathrm{pH}$ & 8 & 18.4 & 1.5 & 4.1 & 2.8 & 27.6 & +69 & +4.8 \\
\hline EX7f & $\mathrm{pH}$ & data set $^{12}$ & 9.4 & 6.6 & 13.5 & 10.9 & 14.1 & -14 & \\
\hline EX8f & $f_{\text {capture }}$ & 0.4 & 16.3 & 5.3 & 12.3 & 9.8 & 10.9 & +50 & -1.2 \\
\hline EX9f & $f_{\text {capture }}$ & 0.8 & 5.4 & 5.3 & 12.3 & 9.8 & 21.7 & -50 & -2.1 \\
\hline EX10f & $\chi_{\mathrm{a}}$ & $0.1 \mu \mathrm{g} \mathrm{m}^{-3}$ & 10.9 & 5.2 & 12.3 & 9.8 & 16.3 & +0 & 0.0 \\
\hline EX11f & $\chi_{a}$ & $1 \mu \mathrm{g} \mathrm{m}^{-3}$ & 10.8 & 5.3 & 12.4 & 9.9 & 16.1 & -1 & 0.0 \\
\hline EX12f & $\mathrm{H}_{2} \mathrm{O}$ depth & $10 \mathrm{~cm}$ & 9.0 & 4.0 & 15.2 & 12.9 & 13.4 & -17 & -0.17 \\
\hline EX13f & $\mathrm{H}_{2} \mathrm{O}$ depth & $2 \mathrm{~cm}$ & 12.9 & 6.8 & 8.3 & 7.2 & 19.3 & +18 & -0.31 \\
\hline EX14f & $K_{D}$ & $\times 0.5$ & 11.8 & 6.1 & 7.6 & 11.3 & 17.7 & +8 & -0.17 \\
\hline EX15f & $K_{D}$ & $\times 2.0$ & 9.6 & 4.2 & 18.3 & 7.9 & 14.4 & -12 & -0.12 \\
\hline EX16f & $r_{\max }$ & $\times 0.5$ & 11.8 & 5.8 & 13.7 & 5.5 & 17.7 & +8 & -0.17 \\
\hline EX17f & $r_{\max }$ & $\times 2.0$ & 9.4 & 4.4 & 10.3 & 16.3 & 14.2 & -14 & -0.14 \\
\hline EX18f & Fert. date ${ }^{13}$ & & 8.4 & 8.6 & 15.5 & 8.6 & 12.6 & -23 & \\
\hline EX19f & Fert. rate ${ }^{14}$ & & 11.3 & 5.6 & 11.5 & 9.1 & 17.0 & +4 & \\
\hline EX20f & Fert decomp. ${ }^{15}$ & & 10.5 & 4.9 & 12.9 & 10.5 & 15.7 & -4 & \\
\hline
\end{tabular}

${ }^{1}$ Control experiment. ${ }^{2}$ Parameter changed from default values. ${ }^{3}$ New parameter value. ${ }^{4} \mathrm{NH}_{3}$ emissions $\left(\mathrm{Tg} \mathrm{N} \mathrm{yr}^{-1}\right) .{ }^{5} \mathrm{Runoff}\left(\mathrm{Tg} \mathrm{N}_{\mathrm{rr}}{ }^{-1}\right)$. ${ }^{6} \mathrm{Diffusion}$ to soil $\left(\mathrm{Tg} \mathrm{N} \mathrm{yr}^{-1}\right){ }^{7}$ Nitrification $\left(\mathrm{Tg} \mathrm{N} \mathrm{yr}^{-1}\right) .{ }^{8}$ Canopy capture $\left(\mathrm{Tg} \mathrm{N} \mathrm{yr}^{-1}\right) .{ }^{9}$ Percent change in $\mathrm{NH}_{3}$ emissions due to parameter change $(\%) .{ }^{10}$ Percent change in $\mathrm{NH}_{3}$ emissions per $\%$ change in parameter value. ${ }^{11}$ Control simulation. ${ }^{12}$ Soil pH from the ISRIC-WISE data set (Batjes, 2005). ${ }^{13}$ Change in fertilizer date to 20 March (NH) and 20 September (SH). ${ }^{14}$ Applying fertilizer over 20 days. ${ }^{15}$ Assuming fast release ammonium nitrate decay of fertilizer. 


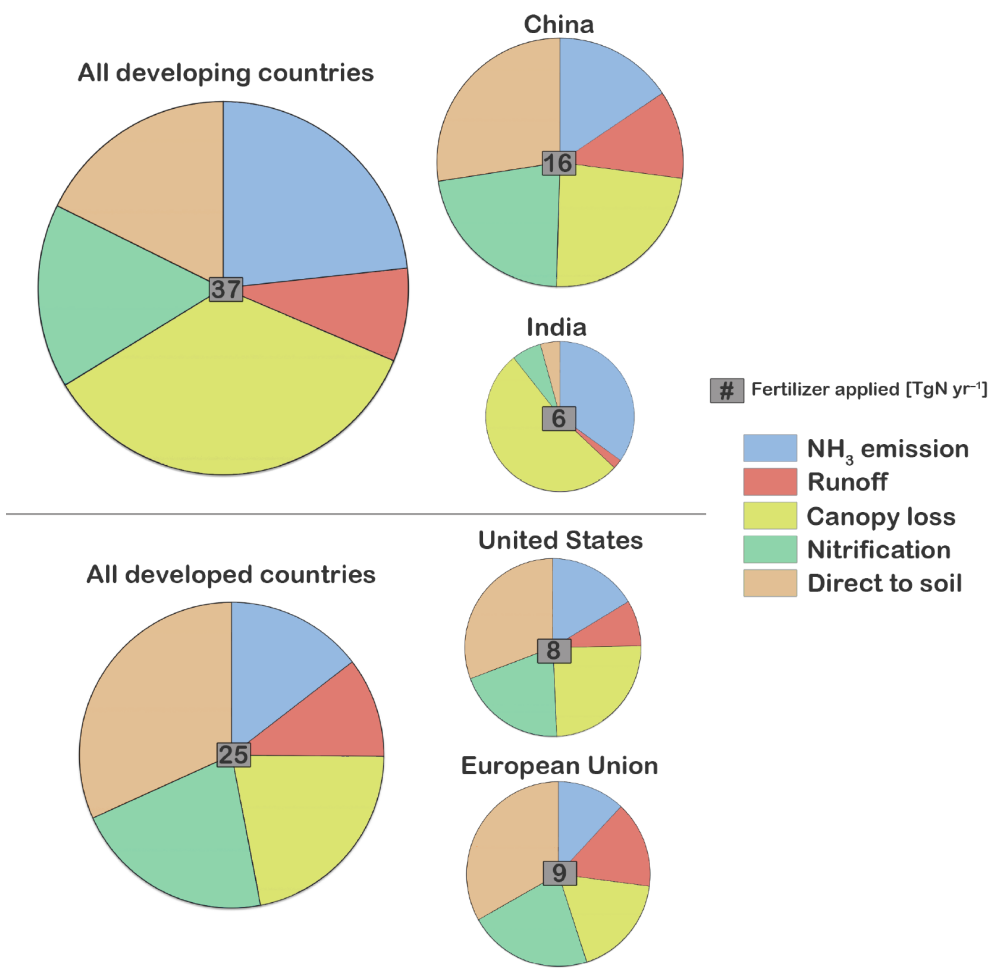

Figure 10. As in Fig. 9 but for fate of TAN nitrogen by country and region. Countries are split between developed countries and developing countries.

\section{(a) Global}

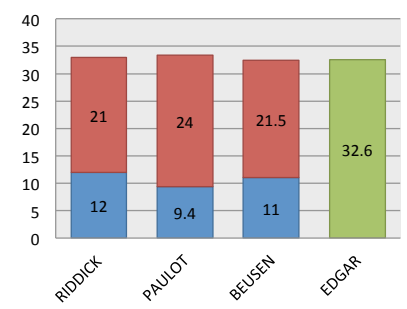

\section{(c) Europe}

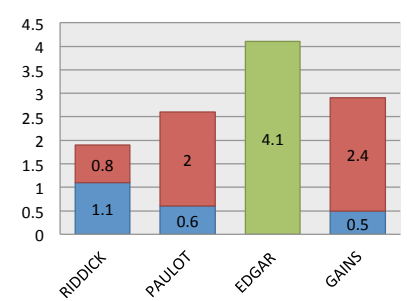

(b) China

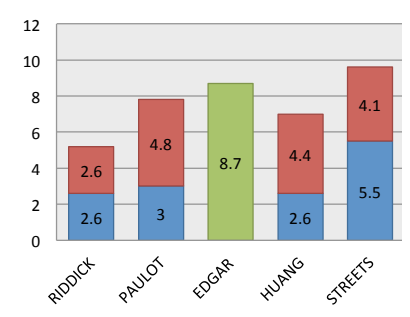

(d) US

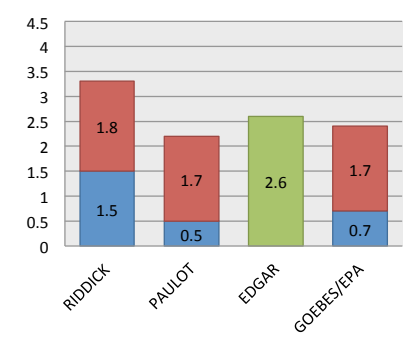

Figure 11. Comparison of manure (red) and synthetic fertilizer (blue) $\mathrm{NH}_{3}$ emissions or combined manure and synthetic fertilizer emissions (green) $\left(\mathrm{Tg} \mathrm{N} \mathrm{yr}^{-1}\right)$ for various inventories (see text for details) and regions: (a) global, (b) China, (c) Europe and (d) US. Emissions from this study are labeled as "Riddick".

sitivity of $\mathrm{NH}_{3}$ emissions to the imposed parameter changes are within the range of $\pm 20 \%$, with many processes within the range of $\pm 10 \%$. The sensitivity to the mechanical mixing of manure into the soil pools (EX1m, EX2m), the adjustment timescale for the water pool (EX3, EX4), the diffusion rate into the soil pools (EX14, EX15), the assumed depth of the water pool (EX12, EX13) and the maximum nitrification rate (EX16, EX17) all impact $\mathrm{NH}_{3}$ emissions by less than $20 \%$. The sensitivity to the assumed background $\mathrm{NH}_{3}$ concentration is also low (EX10, EX11).

The $\mathrm{NH}_{3}$ emissions are most sensitive to changes in $\mathrm{pH}$ (EX5, EX6, EX7). The $\mathrm{NH}_{3}$ emissions decreased by approximately $60 \%$ when the $\mathrm{pH}$ is decreased from 7 to 6 and increased by 50 to $70 \%$ (for manure and synthetic fertilizer, respectively) when the $\mathrm{pH}$ is increased from 7 to 8 . We also test the sensitivity of the emissions to the spatially explicit $\mathrm{pH}$ input from the ISRIC-WISE data set (Batjes, 2005), with a global $\mathrm{pH}$ average of 6.55 (EX7). The spatially explicit $\mathrm{pH}$ reduced the manure $\mathrm{NH}_{3}$ emissions from the control simulation by $23 \%$ and the synthetic fertilizer $\mathrm{NH}_{3}$ emissions by $14 \%$. Changes in $\mathrm{pH}$ also have a large impact on nitrification. Increased $\mathrm{pH}$ reduces $\mathrm{NH}_{4}^{+}(\mathrm{aq})$ and thus the rate of conversion of $\mathrm{NH}_{4}^{+}(\mathrm{aq})$ to $\mathrm{NO}_{3}^{-}$. The effect of $\mathrm{pH}$ on the rate constant for nitrification is not included in the current parameterization. Parton et al. (2001) suggest this effect is small, between a pH of 6 and 8, varying only on the order of $15 \%$. Changes in $\mathrm{pH}$ also result in marked changes in the 

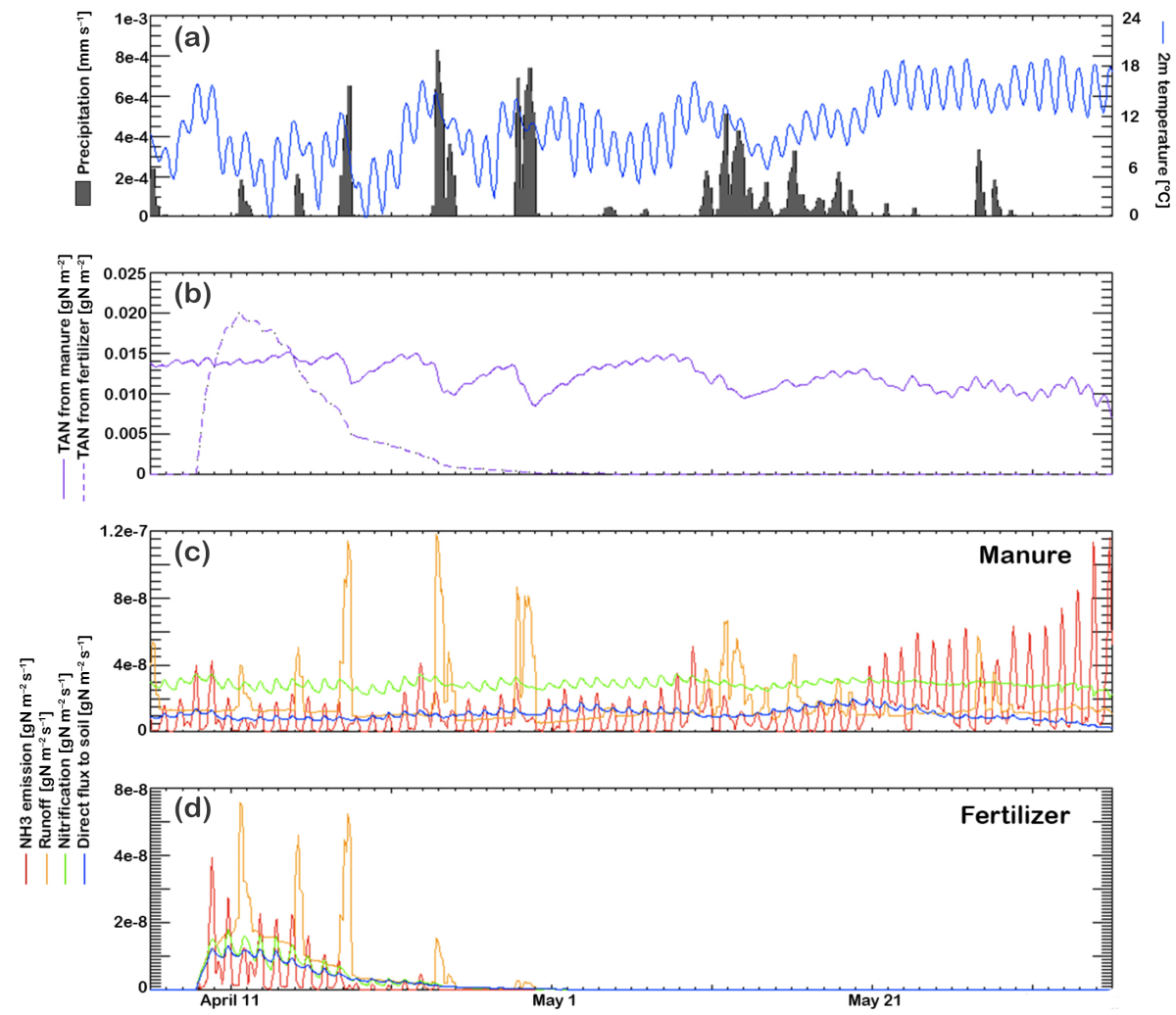

Figure 12. Site-specific pathways for nitrogen budget at $35^{\circ} \mathrm{N}$ and $100^{\circ} \mathrm{W}$, near the Texas panhandle. Panels show (a) the temperature $\left({ }^{\circ} \mathrm{C}\right)$ and precipitation $\left(\mathrm{mm} \mathrm{s}^{-1}\right)$ used to force the CLM, (b) the manure (solid) and synthetic fertilizer TAN pools (dashed) $\left(\mathrm{gN} \mathrm{m}^{-2}\right)$, and the four major loss pathways $\left(\mathrm{g} \mathrm{N} \mathrm{m}^{2} \mathrm{~s}^{-1}\right)$ from (c) the manure TAN pool (d) the synthetic fertilizer TAN pool. Loss pathways: $\mathrm{NH}_{3}$ emissions, red; runoff, orange; nitrification, green; and diffusion to the soil, blue.

runoff and soil diffusion due to the large changes in emissions and nitrification: a low $\mathrm{pH}$ acts to increase the flux of nitrogen through these loss pathways, while a high $\mathrm{pH}$ acts to decrease them.

Emissions are also highly sensitive to changes in canopy capture (i.e., the parameter $f_{\text {capture }}$ ) as shown in EX8 and EX9. Decreasing the fraction captured by the canopy by a factor of 2 increases the emissions by approximately a factor of 3. Changes in this fraction modify the fixed ratio between the amount of nitrogen captured by the canopy and that emitted to the atmosphere. Of course, the nitrogen captured in the canopy can further impact the nitrogen budget, but this impact is not simulated here.

The $\mathrm{NH}_{3}$ emissions are somewhat sensitive to the depth of the assumed water pool (EX12, EX13). Smaller depths (less water) give higher concentrations of all the constituents within the TAN pool resulting in higher $\mathrm{NH}_{3}$ emissions (Eqs. 7 and 12) and larger nitrogen runoff (see Sect. 2.2.4). Larger depths (more water) have the opposite effect. The diffusion of nitrogen into the soil is somewhat sensitive to changes in the assumed water depth as the coefficient of diffusion is proportional to the water content to the $10 / 3$ power (see Appendix A).
We conducted various sensitivities to synthetic fertilizer application. Early synthetic fertilizer application decreases $\mathrm{NH}_{3}$ emissions due to their strong temperature dependence and increase the susceptibility of the TAN pool to runoff. An early fertilization date (set to 20 March in the Northern Hemisphere or 20 September in the Southern Hemisphere) decreases the $\mathrm{NH}_{3}$ emissions by $23 \%$ and increases the nitrogen runoff from the TAN pool by $62 \%$ (EX18f). To investigate the sensitivity to the application rate of synthetic fertilizer, synthetic fertilizer was applied over 20 days as opposed to the single-day application assumed in the default version of the model (EX19f). This did not have a significant impact on the emissions. The assumed synthetic fertilizer type in the default version of the model (urea) was replaced with ammonium nitrate fertilizer in EX20f. Whereas urea is converted to $\mathrm{NH}_{3}$ rather slowly, the conversion of ammonium nitrate is rapid (in the sensitivity test the resulting nitrogen is assumed to be instantaneously released into the TAN pool with no changes in $\mathrm{pH}$ ). However, the emissions are not particularly sensitive to this change. This is in contrast to differences in volatilization rates of different synthetic fertilizers given in Bouwman (2002). Whitehead and Raistrick (1990) show that one of the primary differences between the addition of urea 
(a)

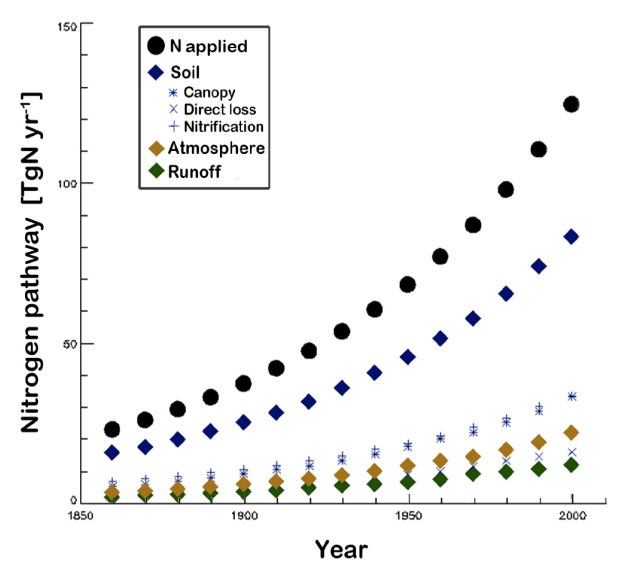

(c)

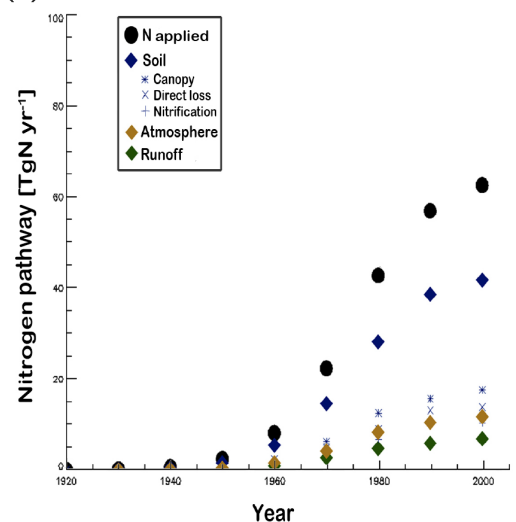

(b) Pathway of $\mathrm{N}$ added by manure

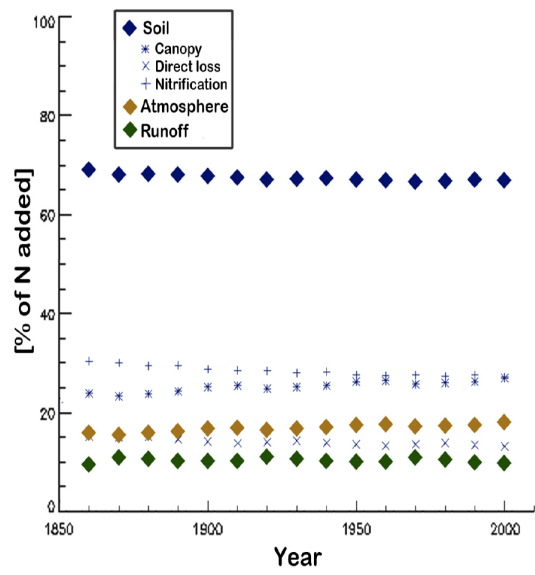

(d)

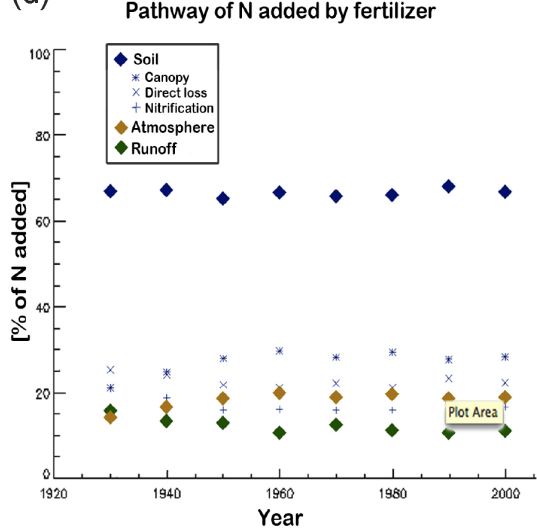

Figure 13. Applied nitrogen and nitrogen losses for the historical simulation in $\mathrm{Tg} \mathrm{N} \mathrm{yr}^{-1}$ for (a) manure and (c) synthetic fertilizer. Nitrogen losses from the TAN pool as a percentage of applied nitrogen for the historical simulation for (b) manure and (d) synthetic fertilizer. The losses from the TAN pool are divided into emission losses of ammonia to the atmosphere (gold diamond), runoff (green diamond) and loss to the soil. Loss to the soil is divided into that due to canopy loss (asterisk) (see Sect. 3.2.3), direct diffusive loss (cross) and nitrification (plus).

vs. ammonium nitrate fertilizer is in the effect of the fertilizer on the soil $\mathrm{pH}$, an effect that we do not consider in this study. In particular urea increases the soil $\mathrm{pH}$ and thus the $\mathrm{NH}_{3}$ emissions.

Finally, we test the impact of manure composition on the $\mathrm{NH}_{3}$ emissions (EX18m). The composition of manure nitrogen excreted by animals depends in part on the digestibility of the feed, which can vary in both time and space. To investigate this uncertainty we varied the composition of the manure assumed in the default model version (50\% urine, $25 \%$ available, $22.5 \%$ resistant and $2.5 \%$ unavailable) to the less soluble $\mathrm{N}$ excreta from dairy cattle in sensitivity simulation EX18m (41\% urine, $21 \%$ available, $25 \%$ unavailable and $13 \%$ resistant; Smith, 1973). This decreased the $\mathrm{NH}_{3}$ emissions by $21 \%$ demonstrating an important sensitivity to the composition of manure and urine.

It is important to emphasize that these sensitivity simulations only test the parameter sensitivity within the imposed model. In particular, the sensitivities to various farming practices are generally extraneous to the model assumptions with some exceptions. The sensitivities to synthetic fertilizer or manure input assumptions are tested in simulations EX18m, EX18f, EX19f, and EX20f; sensitivities to the water depth which may crudely represent some of the impacts of plowing manure or synthetic fertilizer into the soil are examined in EX12 and EX13; and finally, modifications to soil $\mathrm{pH}$ are tested in EX5, EX6 and EX7.

\section{Discussion and conclusions}

In this paper we develop a process-oriented model that predicts the climate-dependent pathways of reactive nitrogen applied as manure or synthetic fertilizer onto the surface of the land. It is also capable of taking into account the resulting biogeochemical cycling of nitrogen. Continued population 
growth will likely result in an increased application of synthetic fertilizers with concurrent increases in manure production in the future (Davidson, 2012). Climate is an important determinant in the ultimate fate of this applied nitrogen, important in determining the resulting emissions of $\mathrm{NH}_{3}$ and other reactive nitrogen gases, in the runoff of the applied nitrogen, its nitrification and its incorporation into the soil organic and inorganic nitrogen pools. The fate of the resultant applied nitrogen may act to acerbate climate change through the formation of $\mathrm{N}_{2} \mathrm{O}$, or perhaps mitigate climate change through increased carbon fertilization and the increased formation of aerosols.

Both natural and anthropogenic processes control agricultural $\mathrm{NH}_{3}$ emissions. Previous global $\mathrm{NH}_{3}$ emission estimates have relied on detailed information on agricultural practices including domestic animal type, animal housing and the field application of synthetic fertilizer or manure (e.g., Bouwman et al., 1997) but have minimized the representation of meteorological processes. In some cases the resulting emission factors have implicitly included temperature dependence by using different emission factors for industrial and developing countries (e.g., Bouwman et al. 1997), although recently some inventories have explicitly included empirical emission factors that vary with temperature (Paulot et al., 2014; Huang et al., 2012). Here, we take the opposite tact by constructing a model where the $\mathrm{N}_{\mathrm{r}}$ pathways and in particular the $\mathrm{NH}_{3}$ emissions following manure and synthetic fertilizer application are explicitly driven by climate but where the explicit representation of most agricultural practices is minimized.

In this study the global emissions of $\mathrm{NH}_{3}$ due to manure and fertilizer nitrogen sources are similar to other recent inventories, with $21 \mathrm{Tg} \mathrm{N} \mathrm{yr}^{-1}$ emitted as $\mathrm{NH}_{3}$ from manure nitrogen and $12 \mathrm{Tg} \mathrm{N} \mathrm{yr}^{-1}$ emitted from synthetic fertilizer for present-day conditions. Strong regional differences in emissions captured by the bottom up inventories are also simulated. Moreover, we are able to simulate the interannual, seasonal and diurnal changes in $\mathrm{NH}_{3}$ emissions critical for air pollution applications (e.g., see de Meij et al., 2006). It is perhaps important to note that the impact of nitrogen emissions on the global carbon budget has generally made use of previous emission inventories without explicit seasonal or diurnal dependence of $\mathrm{NH}_{3}$ emissions and with a rather minimal representation of the geographic meteorological dependence.

The model developed here uses a process-level approach to estimate nitrogen pathways from synthetic fertilizer and manure application. It is suitable for use within an Earth system model to estimate the resulting $\mathrm{NH}_{3}$ emissions, nitrogen runoff, and the incorporation of the nitrogen into soil organic and inorganic matter. The modeled $\mathrm{N}_{\mathrm{r}}$ pathways dynamically respond to climatic variation; for example, (1) the breakdown timescale of manure and fertilizer into TAN depends on temperature; (2) the formation of $\mathrm{NH}_{3}$ gas from the TAN pool is highly temperature-sensitive, with the rate of formation described by the temperature dependence of the thermody- namic Henry and dissociation equilibria for $\mathrm{NH}_{3}$ (Nemitz et al., 2000); (3) the rate of nitrification of $\mathrm{NH}_{3}$ within the TAN pool, determined by the rate at which ammonium ions are oxidized by nitrifying bacteria to form nitrate ions (Abbasi and Adams, 1998), is controlled by environmental factors such as soil temperature and soil moisture; and (4) the runoff of $\mathrm{N}_{\mathrm{r}}$ is determined by the precipitation. Predictions for direct nitrogen runoff from fertilizer and manure nitrogen pools and the incorporation of nitrogen into soil pools from applied fertilizer and manure nitrogen are some of the first made by a global process-level model.

Manure is not a new nitrogen source but rather contains recycled $\mathrm{N}_{\mathrm{r}}$ from soil nitrogen produced when animals eat plants. Therefore, to conserve nitrogen within an Earth system model, the application of manure determines the consumption of plant matter by animals. Specifically, the model calculates the amount of nitrogen and carbon needed for a given manure application and subtracts it from the plant leaf pools within the CLM. The manure production may speed up the decay and processing of plant biomass, releasing different $\mathrm{N}_{\mathrm{r}}$ products to the atmosphere than natural decay (Davidson, 2009).

The climate dependency incorporated into the model suggests that the pathways of nitrogen added to the land are highly spatially and temporally heterogeneous. An examination of nitrogen loss pathways at a point over Texas shows the variation in the nitrogen pathways on a variety of timescales with changes in temperature, precipitation and soil moisture. Globally, $\mathrm{NH}_{3}$ volatilization is highest in the tropics. The percentage of manure nitrogen volatilized to $\mathrm{NH}_{3}$ in this study show a large range in both developing countries (average of $20 \%$; maximum: $36 \%$ ) and industrialized countries (average of $12 \%$; maximum: 39\%). The model also predicts spatial and temporal variability in the amount of $\mathrm{NH}_{3}$ volatilized from synthetic fertilizers, ranging from $14 \%$ (maximum $40 \%$ ) in industrialized countries to $22 \%$ (maximum $40 \%$ ) in developing countries. In comparison, the EDGAR database uses the emission factors based on Bouwman et al. (2002), where 21 and $26 \%$ of manure is converted into $\mathrm{NH}_{3}$ in industrialized and developing countries, respectively. Nitrogen runoff from the manure and synthetic fertilizer TAN pools is highest in areas of high $\mathrm{N}_{\mathrm{r}}$ application and high rainfall, such as China, North America and Europe. Despite high nitrogen input rates we simulate low nitrogen runoff in India and Spain, for example. We also simulate climate-dependent pathways for the diffusion of $\mathrm{N}_{\mathrm{r}}$ into the soil inorganic nitrogen pools and the nitrification of ammonium to nitrate.

Historically we predict emissions of $\mathrm{NH}_{3}$ from applied manure to have increased from approximately $3 \mathrm{Tg} \mathrm{N} \mathrm{yr}^{-1}$ in 1850 to $22 \mathrm{Tg} \mathrm{N} \mathrm{yr}^{-1}$ in 2000 , while the volatilization of fertilizer reaches $12 \mathrm{Tg} \mathrm{N} \mathrm{yr}^{-1}$ in 2000. The $\mathrm{NH}_{3}$ emission factors increase by approximately $3.4 \%$ for manure applications and $11 \%$ for synthetic fertilizer applications over this historical period (1930 to 2000 for fertilizer). Under cur- 
rent manure and synthetic fertilizer application rates we find that globally an additional $1 \mathrm{Tg} \mathrm{NH}_{3}$ is emitted from the manure and synthetic fertilizer pools per degree of warming. Percentage-wise this increases manure emissions by $4 \%$ and synthetic fertilizer emissions by $3 \%$ per degree of temperature increase.

The $\mathrm{NH}_{3}$ emissions appear reasonable when compared to other inventories on the global scale, as well as when compared to the local-scale measurements of manure and synthetic fertilizer (Figs. 2 and 3), although these latter comparisons highlight the difficulty in making global-scale assumptions about surface parameters and farming methodology. The biggest disagreement with the manure emission measurements is from beef cattle feedlots in Texas. On the whole the model performs best when estimating $\mathrm{NH}_{3}$ manure emissions from cows on grassland. Despite the issues described above, this model gives reasonable $\mathrm{NH}_{3}$ emission predictions given the limited global information available on the grazing land of agricultural animals. Measurements of nitrogen runoff from rivers heavily impacted by anthropogenic nitrogen input also compare favorably with simulated results using the river transport model within the CESM (Nevison et al., 2016).

The assumption of simplified farming practices made here may be acceptable in many locations as more complex farming methods are rarely employed in the developing world. While the Food and Agriculture Organization (FAO, 2005) suggests over $75 \%$ of the global agricultural land uses traditional farming methods, one of the largest sources of uncertainty in this study is associated with the simplification of agricultural practices. A number of future model improvements are necessary in the next-generation model.

1. More realistic representation of manure management practices. While there is a wide range of variation in animal housing and storage practices, the unique set of emission factors entailed in animal housing and storage should be incorporated in the next-generation model.

2. A better representation of nitrogen transport throughout the soil column and the resulting $\mathrm{NH}_{3}$ generation. This would allow a differentiation between $\mathrm{NH}_{3}$ emissions resulting from grazing, where urine is rapidly incorporated into the soil column, vs. the emissions resulting from the spreading of manure slurry. It would also allow a representation of fertilizer injection or mixing into the soil column and the transport of nitrogen into the soil column in association with water transport.
3. Representation of $\mathrm{NH}_{3}$ emissions from different synthetic fertilizer types. Different types of synthetic fertilizer have rather different emission factors. As shown by Whitehead and Raistrick (1990) many of these differences can be represented by the impact of the fertilizer on soil $\mathrm{pH}$.

4. A full biogeochemical coupling of the FAN process model to the overall biogeochemistry within the CESM. This would allow the nitrogen introduced through agricultural practices to impact the overall model biogeochemistry and allow a more thorough investigation of the flows of agricultural nitrogen.

5. A full coupling between the $\mathrm{NH}_{3}$ emissions represented by the FAN process model and the atmospheric chemistry model through a PFT-dependent compensation point approach. The applied nitrogen should be added explicitly to the CLM crop model or to pasture land where appropriate.

The increased use of synthetic fertilizer and growing livestock populations has increased $\mathrm{N}_{\mathrm{r}}$ flows to both the atmosphere and oceans to unprecedented levels with a marked effect on the environment. We have provided a first estimate of globally distributed temporal changes in nitrogen pathways from manure and synthetic fertilizer inputs in response to climate. This is relevant to current studies investigating the ecosystem effects of $\mathrm{N}_{\mathrm{r}}$ and, in particular, how adding synthetic fertilizer to farmland affects the ocean and the atmosphere and impacts climate. The model predicts vastly different nitrogen pathways depending on the region the inputs are applied. Scenarios predicting future synthetic fertilizer use and livestock populations suggest large increases in nitrogen added to the land surface from both sources (Tilman et al., 2001; Skjøth and Geels, 2013), with an important component sensitive to climate change. The volatilization of $\mathrm{NH}_{3}$ increases exponentially with temperature, suggesting future emission increases are likely. However, increases in temperature may surpass the optimal temperature at which certain biological processes occur, slowing the process. Washout pathways are also likely to change, not only with climate but also with increases in nitrogen loading. Future applications of this model will investigate the tight coupling between nitrogen, agriculture and climate. 


\section{Appendix A}

Table A1. Description of model variables and equations.

\begin{tabular}{|c|c|c|c|c|}
\hline Description & Symbol & Unit & Value used or equation & Reference \\
\hline & & & \multicolumn{2}{|l|}{ Prognostic Variables } \\
\hline $\begin{array}{l}\text { Pool of nitrogen from ap- } \\
\text { plied manure that easily } \\
\text { forms TAN }\end{array}$ & $\mathrm{N}_{\text {available }}$ & $\mathrm{g} \mathrm{m}^{-2}$ & \multirow{3}{*}{\multicolumn{2}{|c|}{$\begin{array}{l}\mathrm{dN}_{\text {available }} / \mathrm{d} t= \\
f_{\mathrm{a}} \times \alpha_{\text {applied }}(m) \\
-K_{\mathrm{a}} \times \mathrm{N}_{\text {available }}-k_{\mathrm{m}} \times \mathrm{N}_{\text {available }} \\
\mathrm{dN}_{\text {resistant }} / \mathrm{d} t= \\
f_{\mathrm{r}} \times \alpha_{\text {applied }}(m)-K_{\mathrm{r}} \times \mathrm{N}_{\text {resistant }} \\
-k_{\mathrm{m}} \times \mathrm{N}_{\text {resistant }} \\
\mathrm{dN}_{\text {unavailable }} / \mathrm{d} t= \\
f_{\text {un }} \times \alpha_{\text {applied }}(m)-k_{\mathrm{m}} \times \mathrm{N}_{\text {unavailable }}\end{array}$}} \\
\hline $\begin{array}{l}\text { Pool of nitrogen from ap- } \\
\text { plied manure that is resis- } \\
\text { tant to forming TAN }\end{array}$ & $\mathrm{N}_{\text {resistant }}$ & $\mathrm{g} \mathrm{m}^{-2}$ & & \\
\hline $\begin{array}{l}\text { Pool of nitrogen from ap- } \\
\text { plied manure that does not } \\
\text { form TAN }\end{array}$ & $\mathrm{N}_{\text {unavailable }}$ & $\mathrm{g} \mathrm{m}^{-2}$ & & \\
\hline $\begin{array}{l}\text { Pool of nitrogen from ap- } \\
\text { plied fertilizer }\end{array}$ & $\mathrm{N}_{\text {fertilizer }}$ & $\mathrm{g} \mathrm{m}^{-2}$ & \multicolumn{2}{|l|}{$\begin{array}{l}\mathrm{dN}_{\text {fertilizer }} / \mathrm{d} t= \\
\alpha_{\text {applied }}(f) \\
-k_{\mathrm{f}} \times \mathrm{N}_{\text {fertilizer }}\end{array}$} \\
\hline $\begin{array}{l}\text { Pool of nitrogen in TAN } \\
\text { pool from manure }\end{array}$ & $\mathrm{N}_{\mathrm{TAN}}(m)$ & $\mathrm{g} \mathrm{m}^{-2}$ & \multicolumn{2}{|l|}{ 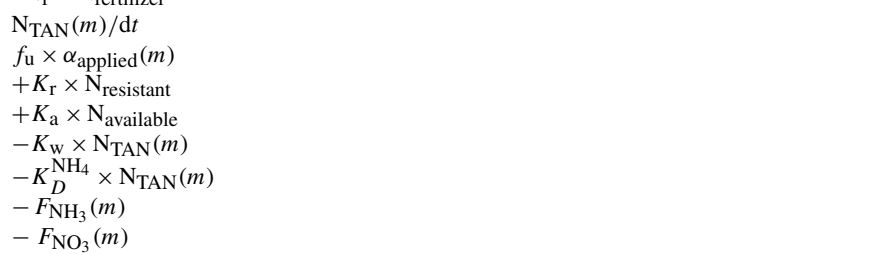 } \\
\hline $\begin{array}{l}\text { Pool of nitrogen in TAN } \\
\text { pool from fertilizer }\end{array}$ & $\mathrm{N}_{\mathrm{TAN}}(f)$ & $\mathrm{g} \mathrm{m}^{-2}$ & \multicolumn{2}{|l|}{$\begin{array}{l}\mathrm{N}_{\mathrm{TAN}}(f) / \mathrm{d} t= \\
+k_{\mathrm{f}} \times \mathrm{N}_{\text {fertilizer }} \\
-K_{\mathrm{W}} \times \mathrm{N}_{\mathrm{TAN}}(f) \\
-K_{D}^{\mathrm{NH}_{4}} \times \mathrm{N}_{\mathrm{TAN}}(f) \\
-F_{\mathrm{NH}_{3}}(f) \\
-F_{\mathrm{NO}_{3}}(f)\end{array}$} \\
\hline Pool of surface $\mathrm{NO}_{3}^{-}$ & $\mathrm{N}_{\mathrm{NO}_{3}}$ & $\mathrm{~g} \mathrm{~m}^{-2}$ & \multicolumn{2}{|l|}{$\mathrm{dN}_{\mathrm{NO}_{3}} / \mathrm{d} t=$} \\
\hline $\begin{array}{l}\text { Pool of manure/fertilizer } \\
\text { water in TAN pool }\end{array}$ & $N_{\text {water }}(m)$ & $\mathrm{m}$ & \multicolumn{2}{|l|}{$\begin{array}{l}F_{\mathrm{NO}_{3}}(m / f)-K_{D}^{\mathrm{NO}_{3}} \times \mathrm{N}_{\mathrm{NO}_{3}} \\
\mathrm{~d} N_{\text {water }}(m) / \mathrm{d} t= \\
s_{\mathrm{W}}(m) \times \alpha_{\text {applied }}(m) \\
-k_{\text {relax }} \times\left(N_{\text {water }}(m)-M_{\text {water }}\right)\end{array}$} \\
\hline $\begin{array}{l}\text { Pool of manure/fertilizer } \\
\text { water in TAN pool }\end{array}$ & $N_{\text {water }}(f)$ & $\mathrm{m}$ & \multicolumn{2}{|l|}{$\begin{array}{l}\mathrm{d} N_{\text {water }}(f) \mathrm{d} t= \\
S_{\mathrm{w}}(f) \times \alpha_{\text {applied }}(f) \\
-k_{\text {relax }} \times\left(N_{\text {water }}(f)-M_{\text {water }}\right)\end{array}$} \\
\hline & & & \multicolumn{2}{|l|}{ Variables from CLM } \\
\hline Ground temperature & $T_{\mathrm{g}}$ & K & Taken from model & \\
\hline Runoff & $R$ & $\mathrm{~m} \mathrm{~s}^{-1}$ & Taken from model & \\
\hline Aerodynamic resistance & $R_{\mathrm{a}}$ & $\mathrm{s} \mathrm{m}^{-1}$ & Taken from model & \\
\hline Boundary layer resistance & $R_{\mathrm{b}}$ & $\mathrm{s} \mathrm{m}^{-1}$ & Taken from model & \\
\hline Water in soil & $M$ & $\mathrm{~m}$ & Taken from the model (top $5 \mathrm{~cm}$ of soil) & \\
\hline & & & \multicolumn{2}{|l|}{ Diagnostic Variables } \\
\hline $\begin{array}{l}\text { Available manure } \\
\text { decomposition }\end{array}$ & $K_{\mathrm{a}}$ & $\mathrm{s}^{-1}$ & $K_{\mathrm{a}}=k_{\mathrm{a} 1} T_{R}\left(T_{\mathrm{g}}\right)$ & $\begin{array}{l}\text { Gilmour et al. (2003); Vigil } \\
\text { and Kissel (1995) }\end{array}$ \\
\hline $\begin{array}{l}\text { Resistant manure } \\
\text { decomposition }\end{array}$ & $K_{\mathrm{r}}$ & $\mathrm{s}^{-1}$ & $K_{\mathrm{r}}=k_{\mathrm{a} 2} T_{R}\left(T_{\mathrm{g}}\right)$ & $\begin{array}{l}\text { Gilmour et al. (2003); Vigil } \\
\text { and Kissel (1995) }\end{array}$ \\
\hline $\begin{array}{l}\text { Temperature dependence } \\
\text { for } K_{\mathrm{a}}, K_{\mathrm{r}}\end{array}$ & $T_{\mathrm{R}}$ & N/A & $T_{\mathrm{R}}\left(T_{\mathrm{g}}\right)=t_{\mathrm{r} 1} \exp \left(t_{\mathrm{r} 2}\left(T_{\mathrm{g}}-273.15\right)\right)$ & (Vigil and Kissel, 1995) \\
\hline Surface runoff flux & $F_{\text {run }}(m / f)$ & $\mathrm{g} \mathrm{m}^{-2} \mathrm{~s}^{-1}$ & \\
\hline $\begin{array}{l}\mathrm{NH}_{4}^{+} \text {loss rate } \\
\text { to soil pool }\end{array}$ & $K_{D}^{\mathrm{NH}_{4}}$ & $\mathrm{~s}^{-1}$ & \multicolumn{2}{|l|}{$\begin{array}{l}F_{\mathrm{run}}(m / f)=R \times \frac{N_{\text {water }}(m / f)}{\mathrm{aq}} \\
K_{D}^{\mathrm{NH}_{4}}=\left(1 / l^{2}\right) \times\left(\Theta_{\mathrm{w}}^{10 / 3} / \varphi^{2}\right) \kappa_{\mathrm{NH}_{4}}\end{array}$} \\
\hline $\begin{array}{l}\mathrm{NO}_{3}^{-} \text {loss rate } \\
\text { to soil pool }\end{array}$ & $K_{D}^{\mathrm{NO}_{3}}$ & $\mathrm{~s}^{-1}$ & $K_{D}^{\mathrm{NO}_{3}}=\left(1 / 1^{2}\right) \times\left(\Theta_{\mathrm{w}}^{10 / 3} / \varphi^{2}\right) \kappa_{\mathrm{NO}_{3}}^{\mathrm{aq}}$ & $\begin{array}{l}\text { Génermont and Cellier } \\
\text { (1997) }\end{array}$ \\
\hline $\begin{array}{l}\text { Base vertical diffusion for } \\
\text { TAN pool }\end{array}$ & $\kappa_{\mathrm{NH}_{4}}^{\mathrm{aq}}$ & $\mathrm{m}^{2} \mathrm{~s}^{-1}$ & $\kappa_{\mathrm{NH}_{4}}^{\mathrm{aq}}=9.8 \times 10^{-10} \times 1.03^{\left(T_{\mathrm{g}}-273.15\right)}$ & $\begin{array}{l}\text { Génermont and Cellier } \\
\text { (1997) }\end{array}$ \\
\hline $\begin{array}{l}\text { Base vertical diffusion for } \\
\mathrm{NO}_{3} \text { pool }\end{array}$ & $\kappa_{\mathrm{NO}_{3}}^{\mathrm{aq}}$ & $\mathrm{m}^{2} \mathrm{~s}^{-1}$ & $\kappa_{\mathrm{NO}_{3}}^{\mathrm{aq}}=1.3 \times 10^{-8} \times 1.03^{\left(T_{\mathrm{g}}-273.15\right)}$ & $\begin{array}{l}\text { Génermont and Cellier } \\
\text { (1997) }\end{array}$ \\
\hline Water Content & $\Theta_{\mathrm{w}}$ & & \multicolumn{2}{|l|}{$\Theta_{\mathrm{w}=} N_{\mathrm{water}}(m / f) / H$} \\
\hline $\begin{array}{l}\text { Flux of nitrogen lost as } \\
\mathrm{NH}_{3} \text { for manure }(m) \text { or fer- } \\
\text { tilizer }(f)\end{array}$ & $F_{\mathrm{NH}_{3}}(m / f)$ & $\mathrm{g} \mathrm{m}^{-2} \mathrm{~s}^{-1}$ & $F_{\mathrm{NH}_{3}}(m / f)=\frac{\mathrm{NH}_{3}(g)(m / f)-\chi_{\mathrm{a}}}{\left(R_{\mathrm{a}}(z)+R_{\mathrm{b}}\right)}$ & $\begin{array}{l}\text { Nemitz et al. (2000; Lou- } \\
\text { bet et al. (2009); Sutton et } \\
\text { al. (2013)) }\end{array}$ \\
\hline
\end{tabular}


Table A1. Continued.

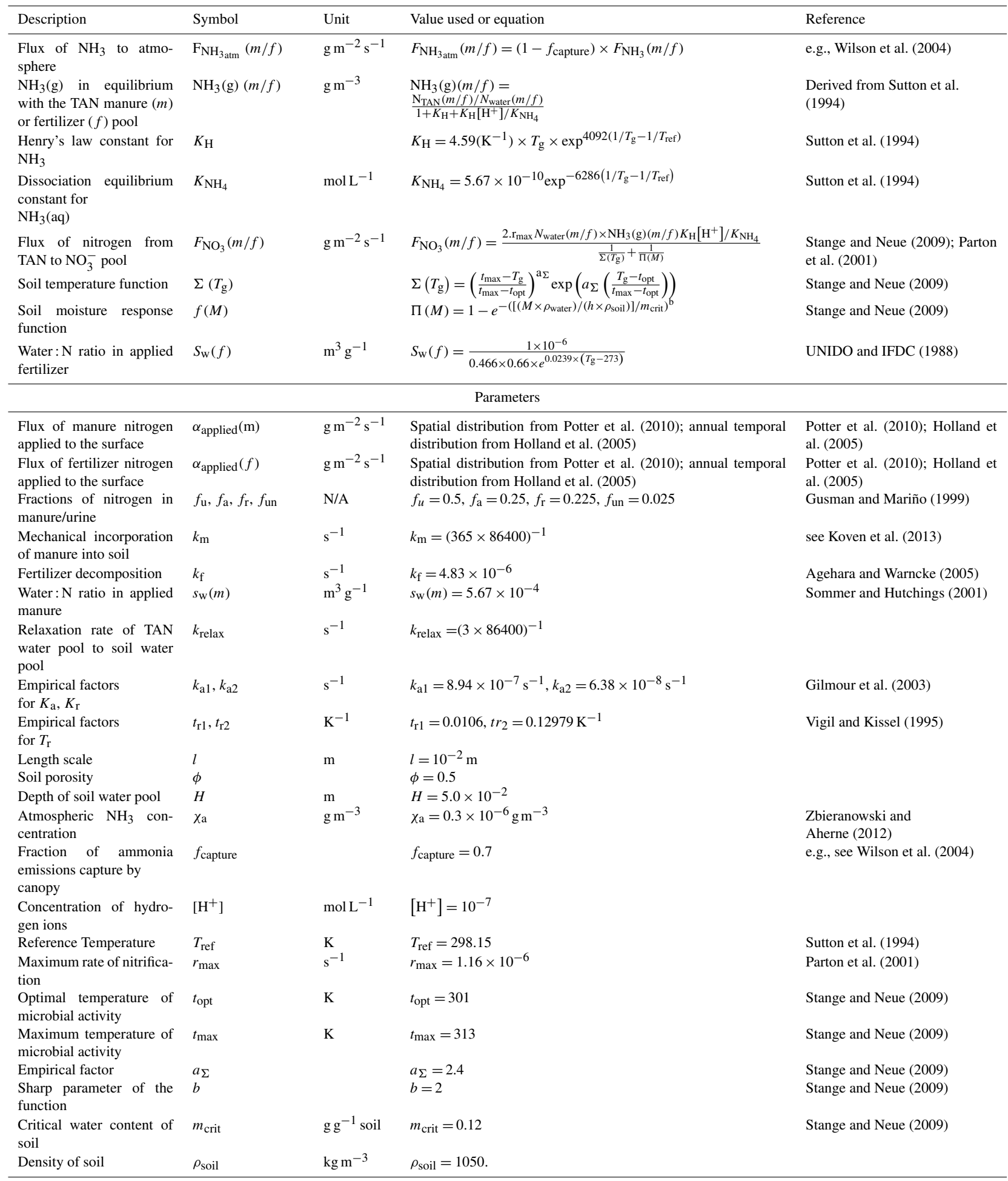




\section{The Supplement related to this article is available online at doi:10.5194/bg-13-3397-2016-supplement.}

Acknowledgements. We wish to thank the reviewers. Also, Farhan Nuruzzaman and Jae Hee Hwang for preparation of input data sets. Thanks also to Sam Levis, Dave Lawrence and Gordon Bonan at NCAR for their input to model processes and colleagues at Cornell University, Ben Brown-Steiner and Raj Paudel, for their help running the model. This project was supported by NSF project number ETBC \#10216.

Edited by: A. Neftel

\section{References}

Abbasi, M. K. and Adams, W. A.: Loss of nitrogen in compacted grassland soil by simultaneous nitrification and denitrification, Plant Soil, 200, 265-277, doi:10.1023/A:1004398520150, 1998.

Adams, P. J., Seinfeld, J. H., Koch, D., Mickley, L., and Jacob, D.: General circulation model assessment of direct radiative forcing by the sulfate-nitrate-ammonium-water inorganic aerosol system, J. Geophys. Res.-Atmos., 106, 1097-1111, doi:10.1029/2000JD900512, 2001.

Agehara, S. and Warncke, D. D.: Soil Moisture and Temperature Effects on Nitrogen Release from Organic Nitrogen Sources, Soil Sci. Soc. Am. J., 69, 1844, doi:10.2136/sssaj2004.0361, 2005.

Bash, J. O., Walker, J. T., Jones, M., Katul, G., Nemitz, E., and Robarge, W.: Estimation of in-canopy ammonia sources and sinks in a fertilized Zea mays field, Environ. Sci. Technol., 44, 16831689, 2010.

Batjes, N.: ISRIC-WISE global data set of derived soil properties on a 0.5 by 0.5 degree grid (Version 3.0), ISRIC-World Soil Inf. Rep, 8, the Netherlands, 24 pp., 2005.

Beusen, A. H. W., Bouwman, A. F., Heuberger, P. S. C., Van Drecht, G., and Van Der Hoek, K. W.: Bottom-up uncertainty estimates of global ammonia emissions from global agricultural production systems, Atmos. Environ., 42, 6067-6077, doi:10.1016/j.atmosenv.2008.03.044, 2008.

Black, A., Sherlock, R., Smith, N., and Cameron, K.: Ammonia Volatilization from Urea Broadcast in Spring on to AutumnSown Wheat, N. Z. J. Crop Hortic. Sci., 17, 175-182, 1989.

Black, A. S., Sherlock, R. R., Smith, N. P., Cameron, K. C., and Goh, K. M.: Effects of Form of Nitrogen, Season, and Urea Application Rate on Ammonia Volatilization from Pastures, N. Z. J. Agric. Res., 28, 469-474, 1985.

Bodirsky, B. L., Popp, A., Weindl, I., Dietrich, J. P., Rolinski, S., Scheiffele, L., Schmitz, C., and Lotze-Campen, $\mathrm{H} .: \mathrm{N}_{2} \mathrm{O}$ emissions from the global agricultural nitrogen cycle - current state and future scenarios, Biogeosciences, 9, 4169-4197, doi:10.5194/bg-9-4169-2012, 2012.

Bouwman, A. F., Lee, D. S., Asman, W. A. H., Dentener, F. J., VanderHoek, K. W., and Olivier, J. G. J.: A global high-resolution emission inventory for ammonia, Global Biogeochem. Cy., 11, 561-587, doi:10.1029/97GB02266, 1997.
Bouwman, A. F., Boumans, L. J. M., and Batjes, N. H.: Estimation of global $\mathrm{NH}_{3}$ volatilization loss from synthetic fertilizers and animal manure applied to arable lands and grasslands, Global Biogeochem. Cy., 16, 1024, doi:10.1029/2000GB001389, 2002.

Bouwman, L., Goldewijk, K. K., Van Der Hoek, K. W., Beusen, A. H. W., Van Vuuren, D. P., Willems, J., Rufino, M. C., and Stehfest, E.: Exploring global changes in nitrogen and phosphorus cycles in agriculture induced by livestock production over the 1900-2050 period, P. Natl. Acad. Sci. USA, 110, 20882-20887, doi:10.1073/pnas.1012878108, 2013.

Bowman, D. C., Paul, J. L., Davis, W. B., and Nelson, S. H.: Reducing Ammonia Volatilization from Kentucky Bluegrass Turf by Irrigation, HortScience, 22, 84-87, 1987.

Branstetter, M. L. and Erickson III, D. J.: Continental runoff dynamics in the Community Climate System Model 2 (CCSM2) control simulation, J. Geophys. Res., 108, 4550, doi:10.1029/2002JD003212, 2003.

Bristow, A. W., Whitehead, D. C., and Cockburn, J. E.: Nitrogenous constituents in the urine of cattle, sheep and goats, J. Sci. Food Agr., 59, 387-394, doi:10.1002/jsfa.2740590316, 1992.

Brouder, S., Hofmann, B., Kladivko, E., Turco, R., Bongen, A., and Frankenberger, J.: Interpreting Nitrate Concentration in Tile Drainage Water, Agronomy Guide, Purdue Extension, AY-318W(1), 2005.

Bussink, D. W.: Ammonia Volatilization from Grassland Receiving Nitrogen-Fertilizer and Rotationally Grazed by Dairy-Cattle, Fert. Res., 33, 257-265, doi:10.1007/BF01050881, 1992.

Bussink, D. W.: Relationships between Ammonia Volatilization and Nitrogen-Fertilizer Application Rate, Intake and Excretion of Herbage Nitrogen by Cattle on Grazed Swards, Fert. Res., 38, 111-121, doi:10.1007/BF00748771, 1994.

Canter, L. W.: Nitrates in Groundwater, CRC Press, 1996.

Catchpoole, V., Oxenham, D., and Harper, L.: Transformation and Recovery of Urea Applied to a Grass Pasture in Southeastern Queensland, Aust. J. Exp. Agr., 23, 80-86, doi:10.1071/EA9830080, 1983.

Chambers, B. J., Lord, E. I., Nicholson, F. A., and Smith, K. A.: Predicting nitrogen availability and losses following application of organic manures to arable land: MANNER, Soil Use Manage. 15, 137-143, 1999.

Dai, A. and Trenberth, K. E.: Estimates of freshwater discharge from continents: Latitudinal and seasonal variations, J. Hydrometeorol., 3, 660-687, 2002.

Davidson, E. A.: The contribution of manure and fertilizer nitrogen to atmospheric nitrous oxide since 1860, Nat. Geosci., 2, 659662, doi:10.1038/NGEO608, 2009.

Davidson, E. A.: Representative concentration pathways and mitigation scenarios for nitrous oxide, Environ. Res. Lett., 7, 024005, doi:10.1088/1748-9326/7/2/024005, 2012.

Del Grosso, S. J., Parton, W. J., Mosier, A. R., Ojima, D. S., Kulmala, A. E., and Phongpan, S.: General model for $\mathrm{N}_{2} \mathrm{O}$ and $\mathrm{N}_{2}$ gas emissions from soils when comparing observed and gas emission rates from irrigated field soils used for model testing $\mathrm{NO}_{2}$, Global Biogeochem. Cy., 14, 1045-1060, 2000.

de Meij, A., Krol, M., Dentener, F., Vignati, E., Cuvelier, C., and Thunis, P.: The sensitivity of aerosol in Europe to two different emission inventories and temporal distribution of emissions, Atmos. Chem. Phys., 6, 4287-4309, doi:10.5194/acp-6-4287-2006, 2006. 
Denmead, O. T., Freney, J. R., and Dunin, F. X.: Gas exchange between plant canopies and the atmosphere: case-studies for ammonia, Atmos. Environ., 42, 3394-3406, 2008.

European Commission, Joint Research Centre (JRC)/Netherlands Environmental Assessment Agency (PBL): Emission Database for Global Atmospheric Research (EDGAR), release version 4.2., http://edgar.jrc.ec.europa.eu (last access: 31 May 2016), 2011.

Eghball, B.: Nitrogen Mineralization from Field-Applied Beef Cattle Feedlot Manure or Compost, Soil Sci. Soc. Am. J., 64, 2024, doi:10.2136/sssaj2000.6462024x, 2000.

Erisman, J. W. and Draaijers, G. P. J.: Atmospheric Deposition in Relation to Acidification and Eutrophication, Studies Environmental Research, vol. 63. Elsevier, Amsterdam, 405 pp., 1995.

FAO: Food and Agriculture Organization-Data on land use, fertilizer management and environment, available at: http://www. fao.org/docrep/004/Y2780E/y2780e05.htm (last access: 31 May 2016), 2005.

Flesch, T. K., Wilson, J. D., Harper, L. A., Todd, R. W., and Cole, N. A.: Determining ammonia emissions from a cattle feedlot with an inverse dispersion technique, Agr. Forest Meteorol., 144, 139155, 2007.

Fowler, D., Coyle, M., Skiba, U., Sutton, M. A., Cape, J. N., Reis, S., Sheppard, L. J., Jenkins, A., Grizzetti, B., and Galloway, J. N.: The global nitrogen cycle in the twenty-first century, Philos. T. R. Soc. Lond. B, 368, 20130164, doi:10.1098/rstb.2013.0164, 2013.

Galloway, J. N., Dentener, F. J., Capone, D. G., Boyer, E. W., Howarth, R. W., Seitzinger, S. P., Asner, G. P., Cleveland, C. C., Green, P. A., Holland, E. A., Karl, D. M., Michaels, A. F., Porter, J. H., Townsend, A. R., and Vorosmarty, C. J.: Nitrogen cycles: past, present, and future, Biogeochemistry, 70, 153-226, doi:10.1007/s10533-004-0370-0, 2004.

Génermont, S. and Cellier, P.: A mechanistic model for estimating ammonia volatilization from slurry applied to bare soil, Agr. Forest Meteorol., 88, 145-167, doi:10.1016/S0168-1923(97)00044$0,1997$.

Gilbert, P. M., Harrison, J., Heil, C., and Seitzinger, S.: Escalating Worldwide use of Urea - A Global Change Contributing to Coastal Eutrophication, Biogeochemistry, 77, 441-463, doi:10.1007/s10533-005-3070-5, 2006.

Gilmour, J. T., Cogger, C. G., Jacobs, L. W., Evanylo, G. K., and Sullivan, D. M.: Decomposition and plant-available nitrogen in biosolids: laboratory studies, field studies, and computer simulation, J. Environ. Qual., 32, 1498-507, 2003.

Goebes, M. D., Strader, R., and Davidson, C.: An ammonia emission inventory for fertilizer application in the United States, Atmos. Environ., 37, 2539-2550, doi:10.1016/S13522310(03)00129-8, 2003.

Gu, B., Sutton, M. A., Chang, S. X., Ge, Y., and Chang, J.: Agricultural ammonia emissions contribute to China's urban air pollution, Front. Ecol. Environ., 12, 265-266, doi:10.1890/14.WB.007, 2014.

Gusman, A. J. and Mariño, M. A.: Analytical Modeling of Nitrogen Dynamics in Soils and Ground Water, J. Irrig. Drainage E., 125, 330-337, doi:10.1061/(ASCE)07339437(1999)125:6(330), 1999.

Hamaoui-Laguel, L., Meleux, F., Beekmann, M., Bessagnet, B., Génermont, S., Cellier, P., and Létinois, L.: Improving ammonia emissions in air quality modelling for France, Atmos. Environ., 92, 584-595, doi:10.1016/j.atmosenv.2012.08.002, 2014.

Hargrove, W. L. and Kissel, D. E.: Ammonia Volatilization from Surface Applications of Urea in the Field and Laboratory, Soil Sci. Soc. Am. J., 43, 359-363, 1979.

Harper, L. A., Denmead, O. T., and Sharpe, R. R.: Identifying sources and sinks of scalars in a corn canopy with inverse Lagrangian dispersion analysis II. Ammonia, Agr. Forest Meteorol., 104, 75-83, 2000.

Hauglustaine, D. A., Balkanski, Y., and Schulz, M.: A global model simulation of present and future nitrate aerosols and their direct radiative forcing of climate, Atmos. Chem. Phys., 14, 1103111063, doi:10.5194/acp-14-11031-2014, 2014.

Heald, C. L., Collett Jr., J. L., Lee, T., Benedict, K. B., Schwandner, F. M., Li, Y., Clarisse, L., Hurtmans, D. R., Van Damme, M., Clerbaux, C., Coheur, P.-F., Philip, S., Martin, R. V., and Pye, H. O. T.: Atmospheric ammonia and particulate inorganic nitrogen over the United States, Atmos. Chem. Phys., 12, 10295-10312, doi:10.5194/acp-12-10295-2012, 2012.

Holland, E. A., Lee-Taylor, J., Nevison, C. D., and Sulzman, J.: Global $\mathrm{N}$ Cycle: Fluxes and $\mathrm{N}_{2} \mathrm{O}$ Mixing Ratios Originating from Human Activity, Data set, available at: http: //www.daac.ornl.gov, Oak Ridge National Laboratory Distributed Active Archive Center, Oak Ridge, Tennessee, USA, doi:10.3334/ORNLDAAC/797, 2005.

Howarth, R. W., Sharpley, A., and Walker, D.: Sources of nutrient pollution to coastal waters in the United States: Implications for achieving coastal water quality goals, Estuaries, 25, 656-676, doi:10.1007/BF02804898, 2002.

Huang, X., Song, Y., Li, M., Li, J., Huo, Q., Cai, X., Zhu, T., Hu, M., and Zhang, H.: A high-resolution ammonia emission inventory in China, Global Biogeochem. Cy., 26, GB1030, doi:10.1029/2011GB004161, 2012.

Hudman, R. C., Russell, A. R., Valin, L. C., and Cohen, R. C.: Interannual variability in soil nitric oxide emissions over the United States as viewed from space, Atmos. Chem. Phys., 10, 99439952, doi:10.5194/acp-10-9943-2010, 2010.

Hurrell, J. W., Holland, M. M., Gent, P. R., Ghan, S., Kay, J. E., Kushner, P. J., Lamarque, J.-F., Large, W. G., Lawrence, D., Lindsay, K., Lipscomb, W. H., Long, M. C., Mahowald, N., Marsh, D. R., Neale, R. B., Rasch, P., Vavrus, S., Vertenstein, M., Bader, D., Collins, W. D., Hack, J. J., Kiehl, J., and Marshall, S.: The Community Earth System Model: A Framework for Collaborative Research, B. Am. Meteorol. Soc., 94, 13391360, doi:10.1175/BAMS-D-1112-00121, 2013.

Jarvis, S. C., Hatch, D. J., and Lockyer, D. R.: Ammonia Fluxes from Grazed Grassland - Annual Losses from Cattle Production Systems and their Relation to Nitrogen Inputs, J. Agric. Sci., 113, 99-108, 1989.

Jury, W. A., Spencer, W. F., and Farmer, W. J.: Behavior Assessment Model for Trace Organics in Soil: I. Model Description1, J. Environ. Qual., 12, 558-564, doi:10.2134/jeq1983.00472425001200040025x, 1983.

Keppel-Aleks, G., Randerson, J. T., Lindsay, K., Stephens, B. B., Keith Moore, J., Doney, S. C., Thornton, P. E., Mahowald, N. M., Hoffman, F. M., Sweeney, C., Tans, P. P., Wennberg, P. O., and Wofsy, S. C.: Atmospheric Carbon Dioxide Variability in the Community Earth System Model: Evaluation and Transient Dy- 
namics during the Twentieth and Twenty-First Centuries, J. Climate, 26, 4447-4475, doi:10.1175/JCLI-D-12-00589.1, 2013.

Klimont, Z. and Brink, C.: Modelling of emissions of air pollutants and greenhouse gases from agricultural sources in Europe, Tech. Rep., IIASA, 2004.

Koven, C. D., Riley, W. J., Subin, Z. M., Tang, J. Y., Torn, M. S., Collins, W. D., Bonan, G. B., Lawrence, D. M., and Swenson, S. C.: The effect of vertically resolved soil biogeochemistry and alternate soil $\mathrm{C}$ and $\mathrm{N}$ models on $\mathrm{C}$ dynamics of CLM4, Biogeosciences, 10, 7109-7131, doi:10.5194/bg-10-7109-2013, 2013.

Lamarque, J.-F., Bond, T. C., Eyring, V., Granier, C., Heil, A., Klimont, Z., Lee, D., Liousse, C., Mieville, A., Owen, B., Schultz, M. G., Shindell, D., Smith, S. J., Stehfest, E., Van Aardenne, J., Cooper, O. R., Kainuma, M., Mahowald, N., McConnell, J. R., Naik, V., Riahi, K., and van Vuuren, D. P.: Historical (1850-2000) gridded anthropogenic and biomass burning emissions of reactive gases and aerosols: methodology and application, Atmos. Chem. Phys., 10, 7017-7039, doi:10.5194/acp10-7017-2010, 2010.

Lamarque, J.-F., Shindell, D. T., Josse, B., Young, P. J., Cionni, I., Eyring, V., Bergmann, D., Cameron-Smith, P., Collins, W. J., Doherty, R., Dalsoren, S., Faluvegi, G., Folberth, G., Ghan, S. J., Horowitz, L. W., Lee, Y. H., MacKenzie, I. A., Nagashima, T., Naik, V., Plummer, D., Righi, M., Rumbold, S. T., Schulz, M., Skeie, R. B., Stevenson, D. S., Strode, S., Sudo, K., Szopa, S., Voulgarakis, A., and Zeng, G.: The Atmospheric Chemistry and Climate Model Intercomparison Project (ACCMIP): overview and description of models, simulations and climate diagnostics, Geosci. Model Dev., 6, 179-206, doi:10.5194/gmd-6-179-2013, 2013a.

Lamarque, J.-F., Dentener, F., McConnell, J., Ro, C.-U., Shaw, M., Vet, R., Bergmann, D., Cameron-Smith, P., Dalsoren, S., Doherty, R., Faluvegi, G., Ghan, S. J., Josse, B., Lee, Y. H., MacKenzie, I. A., Plummer, D., Shindell, D. T., Skeie, R. B., Stevenson, D. S., Strode, S., Zeng, G., Curran, M., Dahl-Jensen, D., Das, S., Fritzsche, D., and Nolan, M.: Multi-model mean nitrogen and sulfur deposition from the Atmospheric Chemistry and Climate Model Intercomparison Project (ACCMIP): evaluation of historical and projected future changes, Atmos. Chem. Phys., 13, 7997-8018, doi:10.5194/acp-13-7997-2013, 2013 b.

Lawrence, D. M., Thornton, P. E., Oleson, K. W., and Bonan, G. B.: The partitioning of evapotranspiration into transpiration, soil evaporation, and canopy evaporation in a GCM: Impacts on land-atmosphere interaction, J. Hydrometeorol., 8, 862-880, doi:10.1175/JHM596.1, 2007.

Lawrence, D. M., Oleson, K. W., Flanner, M. G., Fletcher, C. G., Lawrence, P. J., Levis, S. S., Swenson, C., and Bonan, G. B.: The CCSM4 land simulation, 1850-2005: Assessment of surface climate and new capabilities, J. Climate, 25, 2240-2260, 2012.

Lindsay, K., Bonan, G., Doney, S., Hofffman, F., Lawrence, D., Long, M. C., Mahowald, N., Moore, J. K., Randerson, J. T., and Thornton, P.: Preindustrial and 20th century experiments with the Earth System Model CESM1-(BGC), J. Climate, 27, 8981-9005, 2014.

Levis, S., Bonan, G. B., Kluzek, E., Thornton, P. E., Jones, A., Sacks, W. J., and Kucharik, C. J.: Interactive Crop Management in the Community Earth System Model (CESM1): Seasonal Influences on Land-Atmosphere Fluxes, J. Climate, 25, 48394859, doi:10.1175/JCLI-D-11-00446.1, 2012.
Li, C., Salas, W., Zhang, R., Krauter, C., Rotz, A., and Mitloehner, F.: Manure-DNDC: a biogeochemical process model for quantifying greenhouse gas and ammonia emissions from livestock manure systems, Nutr. Cycl. Agroecosys., 93, 163-200, doi:10.1007/s10705-012-9507-z, 2012.

Loubet, B., Asman, W. A. H., Theobald, M. R., Hertel, O., Tang, S. Y., Robbin, P., Hassouna, M., Daemmgen, U., Germont, S., Cellier, P., and Sutton, M. A.: Ammonia deposition near hot spots: processes, models and monitoring methods, in: Atmospheric ammonia: detecting emission changes and environmental impacts. Results of an expert workshop under the convention on longrange transboundary air pollution, edited by: Sutton, M., Reis, S., and Baker, S., Springer, Heidelberg, 205-267, 2009.

Massad, R.-S., Nemitz, E., and Sutton, M. A.: Review and parameterisation of bi-directional ammonia exchange between vegetation and the atmosphere, Atmos. Chem. Phys., 10, 10359-10386, doi:10.5194/acp-10-10359-2010, 2010.

Mayorga, E., Seitzinger, S. P., Harrison, J. A., Dumont, E., Beusen, A. H. W., Bouwman, A. F., Fekete, B. M., Kroeze, C., and Van Drecht, G.: Global Nutrient Export from WaterSheds 2 (NEWS 2): Model development and implementation, Environ. Modell. Softw., 25, 837-853, doi:10.1016/j.envsoft.2010.01.007, 2010.

Mitsch, W. J. and Gosselink, J. G.: Wetlands, John Wiley and Sons, Hoboken, NJ, 2007.

Mulvaney, M. J., Cummins, K. A., Wood, C. W., Wood, B. H., and Tyler, P. J.: Ammonia Emissions from Field-Simulated Cattle Defecation and Urination, J. Environ. Qual., 37, 2022-2027, doi:10.2134/jeq2008.0016, 2008.

Myhre, G., Samset, B. H., Schulz, M., Balkanski, Y., Bauer, S., Berntsen, T. K., Bian, H., Bellouin, N., Chin, M., Diehl, T., Easter, R. C., Feichter, J., Ghan, S. J., Hauglustaine, D., Iversen, T., Kinne, S., Kirkevåg, A., Lamarque, J.-F., Lin, G., Liu, X., Lund, M. T., Luo, G., Ma, X., van Noije, T., Penner, J. E., Rasch, P. J., Ruiz, A., Seland, Ø., Skeie, R. B., Stier, P., Takemura, T., Tsigaridis, K., Wang, P., Wang, Z., Xu, L., Yu, H., Yu, F., Yoon, J.-H., Zhang, K., Zhang, H., and Zhou, C.: Radiative forcing of the direct aerosol effect from AeroCom Phase II simulations, Atmos. Chem. Phys., 13, 1853-1877, doi:10.5194/acp-13-18532013, 2013.

Nason, G. E. E., Pluth, D. J., and McGill, W. B.: Volatiliation and foliar recapture of ammonia following spring and fall application of ${ }^{15} \mathrm{~N}$ urea to a Douglas-fir ecosystem, Soil Sci. Soc. Am. J., 52, 821-828, 1988.

Nemitz, E., Sutton, M. A., Schjoerring, J. K., Husted, S., and Wyers, G. P.: Resistance modelling of ammonia exchange over oilseed rape, Agr. Forest Meteorol., 105, 405-425, doi:10.1016/S01681923(00)00206-9, 2000.

Nevison, C. D., Hess, P. G., Riddick, S., and Ward, D.: Denitrification, leaching and river nitrogen export in the Community Land Model, J. Adv. Model. Earth Syst., 8, 272-291, doi:10.1002/2015MS000573, 2016.

Oleson, K. W., Niu, G.-Y., Yang, Z.-L., Lawrence, D. M., Thornton, P. E., Lawrence, P. J., Stöckli, R., Dickinson, R. E., Bonan, G. B., Levis, S., Dai, A., and Qian, T.: Improvements to the Community Land Model and their impact on the hydrological cycle, J. Geophys. Res.-Biogeo., 113, G01021, doi:10.1029/2007JG000563, 2008.

Parton, W. J., Mosier, A. R., Ojima, D. S., Valentine, D. W., Schimel, D. S., Weier, K., and Kulmala, A. E.: Generalized 
model for $\mathrm{N}_{2}$ and $\mathrm{N}_{2} \mathrm{O}$ production from nitrification and denitrification, Global Biogeochem. Cy., 10, 401-412, 1996.

Parton, W. J., Holland, E. A., Grosso, S. J. Del, Hartman, M. D., Martin, R. E., Mosier, A. R., Ojima, D. S., and Schimel, D. S.: Generalized model for $\mathrm{NO}_{\mathrm{x}}$ and $\mathrm{N}_{2} \mathrm{O}$ emissions from soils, J. Geophys. Res, 106, 17403-17491, 2001.

Paulot, F., Jacob, D. J., Pinder, R. W., Bash, J. O., Travis, K., and Henze, D. K.: Ammonia emissions in the United States, European Union, and China derived by high-resolution inversion of ammonium wet deposition data: Interpretation with a new agricultural emissions inventory (MASAGE_NH3), J. Geophys. Res.-Atmos., 119, 4343-4364, doi:10.1002/2013JD021130, 2014.

Pinder, R. W., Pekney, N. J., Davidson, C. I., and Adams, P. J.: A process-based model of ammonia emissions from dairy cows: Improved temporal and spatial resolution, Atmos. Environ., 38, 1357-1365, doi:10.1016/j.atmosenv.2003.11.024, 2004.

Potter, P., Ramankutty, N., Bennett, E. M., and Donner, S. D.: Characterizing the Spatial Patterns of Global Fertilizer Application and Manure Production, Earth Interact., 14, 1-22, doi:10.1175/2009EI288.1. 2010.

Qian, T., Dai, A., Trenberth, K. E., and Oleson, K. W.: Simulation of Global Land Surface Conditions from 1948 to 2004. Part I: Forcing Data and Evaluations, J. Hydrometeorol., 7, 953-975, doi:10.1175/JHM540.1, 2006.

Randerson, J. T., Hoffman, F. M., Thornton, P. E., Mahowald, N. M., Lindsay, K., Lee, Y., Nevison, C. D., Doney, S. C., Bonan, G., Stoeckli, R., Covey, C., Running, S. W., and Fung, I. Y.:. Systematic assessment of terrestrial biogeochemistry in coupled climate-carbon models, Glob. Change Biol., 15, 2462-2484, doi:10.1111/j.1365-2486.2009.01912.x, 2009.

Riddick, S. N.: The global ammonia emission from seabirds, $\mathrm{PhD}$ thesis, King's College, London, 2012.

Sheard, R. W. and Beauchamp, E. G.: Aerodyanmic measurement of ammonium volatilization from urea applied to bluegrass fescue turf, paper presented at 5th Int. Turfgrass Res. Conf., Avignon, France, 1-5 July, INRA Paris, France, 1985.

Shindell, D. T., Lamarque, J.-F., Schulz, M., Flanner, M., Jiao, C., Chin, M., Young, P. J., Lee, Y. H., Rotstayn, L., Mahowald, N., Milly, G., Faluvegi, G., Balkanski, Y., Collins, W. J., Conley, A. J., Dalsoren, S., Easter, R., Ghan, S., Horowitz, L., Liu, X., Myhre, G., Nagashima, T., Naik, V., Rumbold, S. T., Skeie, R., Sudo, K., Szopa, S., Takemura, T., Voulgarakis, A., Yoon, J.-H., and Lo, F.: Radiative forcing in the ACCMIP historical and future climate simulations, Atmos. Chem. Phys., 13, 2939-2974, doi:10.5194/acp-13-2939-2013, 2013.

Skjøth, C. A. and Geels, C.: The effect of climate and climate change on ammonia emissions in Europe, Atmos. Chem. Phys., 13, 117-128, doi:10.5194/acp-13-117-2013, 2013.

Skjøth, C. A., Geels, C., Berge, H., Gyldenkærne, S., Fagerli, H., Ellermann, T., Frohn, L. M., Christensen, J., Hansen, K. M., Hansen, K., and Hertel, O.: Spatial and temporal variations in ammonia emissions - a freely accessible model code for Europe, Atmos. Chem. Phys., 11, 5221-5236, doi:10.5194/acp-11-52212011, 2011.

Smil, V.: Feeding the world: a challenge for the twenty-first century, Cambridge, MA, USA, MIT Press, 388 pp., 2000.
Smith, L. W.: Nutritive evaluations of animal manures. Symposium: processing agricultural and municipal wastes, edited by: Inglett, G. E., Avi. Publ. Co., Westport, CT, 1973.

Sommer, S. G. and Hutchings, N. J.: Ammonia emission from field applied manure and its reduction-invited paper, Eur. J. Agron., $15,1-15,2001$.

Sparks, J. P.: Ecological ramifications of the direct foliar uptake of nitrogen, Oecologia, 159, 1-13, doi:10.1007/s00442-008-11886, 2009.

Stange, C. F. and Neue, H.-U.: Measuring and modelling seasonal variation of gross nitrification rates in response to long-term fertilisation, Biogeosciences, 6, 2181-2192, doi:10.5194/bg-62181-2009, 2009.

Stoeckli, R., Lawrence, D. M., Niu, G. Y., Oleson, K. W., Thornton, P. E., Yang, Z.-L., Bonan, G. B., Denning, A. S., and Running, S. W.: Use of FLUXNET in the community land model development, J. Geophys. Res.-Biogeo., 113, G01025, doi:10.1029/2007JG000562, 2008.

Streets, D. G.: An inventory of gaseous and primary aerosol emissions in Asia in the year 2000, J. Geophys. Res., 108, 8809, doi:10.1029/2002JD003093, 2003.

Sutton, M. A., Asman, W. A. H., and Schjorring, J. K.: Dry Deposition of Reduced Nitrogen, Tellus B, 46, 255-273, doi:10.1034/j.1600-0889.1994.t01-2-00002.x, 1994.

Sutton, M. A., Reis, S., Billen, G., Cellier, P., Erisman, J. W., Mosier, A. R., Nemitz, E., Sprent, J., van Grinsven, H., Voss, M., Beier, C., and Skiba, U.: Preface "Nitrogen \& Global Change", Biogeosciences, 9, 1691-1693, doi:10.5194/bg-9-1691-2012, 2012.

Sutton, M. A., Reis, S., Riddick, S. N., Dragosits, U., Nemitz, E., Theobald, M. R., Tang, Y. S., Braban, C. F., Vieno, M., Dore, A. J., Mitchell, R. F., Wanless, S., Daunt, F., Fowler, D., Blackall, T. D., Milford, C., Flechard, C. R., Loubet, B., Massad, R., Cellier, P., Personne, E., Coheur, P. F., Clarisse, L., Van Damme, M., Ngadi, Y., Clerbaux, C., Skjoth, C. A., Geels, C., Hertel, O., Kruit, R. J. W., Pinder, R. W., Bash, J. O., Walker, J. T., Simpson, D., Horvath, L., Misselbrook, T. H., Bleeker, A., Dentener, F., and de Vries, W.: Towards a climate-dependent paradigm of ammonia emission and deposition, Philos. T. R. Soc. B, 368, 20130166, doi:10.1098/rstb.2013.0166, 2013.

Thomas, R. Q., Bonan, G. B., and Goodale, C. L.: Insights into mechanisms governing forest carbon response to nitrogen deposition: a model-data comparison using observed responses to nitrogen addition, Biogeosciences, 10, 3869-3887, doi:10.5194/bg-10-3869-2013, 2013.

Thornton, P., Lamarque, J. F., Rosenbloom, N. A., and Mahowald, $\mathrm{N}$.: Influence of carbon-nitrogen cycle coupling on land model response to $\mathrm{CO}_{2}$ fertilization and climate variability, Global Biogeochem. Cy., 21, doi:10.1029/2006GB002868, 2007.

Thornton, P. E., Doney, S. C., Lindsay, K., Moore, J. K., Mahowald, N., Randerson, J. T., Fung, I., Lamarque, J.-F., Feddema, J. J., and Lee, Y.-H.: Carbon-nitrogen interactions regulate climate-carbon cycle feedbacks: results from an atmosphereocean general circulation model, Biogeosciences, 6, 2099-2120, doi:10.5194/bg-6-2099-2009, 2009.

Tilman, D., Fargione, J., Wolff, B., D’Antonio, C., Dobson, A., Howarth, R., Schindler, D., Schlesinger, W. H., Simberloff, D., and Swackhamer, D.: Forecasting agriculturally 
driven global environmental change, Science, 292, 281-284, doi:10.1126/science.1057544, 2001.

Todd, R. W., Cole, N. A., Harper, L. A., and Flesch, T. K.: Flux gradient estimates of ammonia emissions from beef cattle feedyard pens, International Symposium on Air Quality and Waste Management for Agriculture, 16-19 September 2007, Broomfield, Colorado 701P0907cd, doi:10.13031/2013.23877, 2007.

Turner, R. E. and Rabalais, N. N.: Changes in Mississippi River Water-Quality this Century, Bioscience, 41, 140-147, doi:10.2307/1311453, 1991.

United Nations Industrial Development Organization (UNIDO) and International Fertilizer Development Center (IFDC) (Eds.): Fertilizer Manual, Kluwer Academic Publishers, Dordrecht, the Netherlands, 1988.

US EPA: National Emission Inventory: Ammonia Emissions from Animal Husbandry Operations Draft Report, https://www3.epa. gov/ttnchie1/ap42/ch09/related/nh3inventorydraft_jan2004.pdf (last access: 31 May 2016), 2004.

Vaio, N., Cabrera, M. L., Kissel, D. E., Rema, J. A., Newsome, J. F., and Calvert, V. H.: Ammonia Volatilization from Urea-Based Fertilizers Applied to Tall Fescue Pastures in Georgia, USA, Soil Sci. Soc. Am. J., 72, 1665-1671, doi:10.2136/sssaj2007.0300, 2008.

Van Drecht, G., Bouwman, A. F., Knoop, J. M., Beusen, A. H. W., and Meinardi, C. R.: Global modeling of the fate of nitrogen from point and nonpoint sources in soils, groundwater, and surface water, Global Biogeochem. Cy., 17, 1115, doi:10.1029/2003GB002060, 2003.

Vigil, M. F. and Kissel, D. E.: Rate of Nitrogen Mineralized from Incorporated Crop Residues as Influenced by Temperature, Soil Sci. Soc. Am. J., 59, 1636, doi:10.2136/sssaj1995.03615995005900060019x, 1995.
Visek, W. J.: Ammonia: its effects on biological systems, metabolic hormones, and reproduction, J. Dairy Sci., 67, 481-498, 1984.

Walker, J. T., Robarge, W. P., Wu, Y., and Meyers, T. P.: Measurement of bi-directional ammonia fluxes over soybean using the modified Bowen-ratio technique, Agr. Forest Meteorol., 138, 54 68, doi:10.1016/j.agrformet.2006.03.011, 2006.

Warner, J. X., Wei, Z., Strow, L. L., Dickerson, R. R., and Nowak, J. B.: The global tropospheric ammonia distribution as seen in the 13-year AIRS measurement record, Atmos. Chem. Phys., 16, 5467-5479, doi:10.5194/acp-16-5467-2016, 2016.

Wilson, L. J., Bacon, P. J., Bull, J., Dragosits, U., Blackall, T. D., Dunn, T. E., Hamer, K. C., Sutton, M. A., and Wanless, S.: Modelling the spatial distribution of ammonia emissions from seabirds, Environ. Pollut., 131, 173-185, 2004.

Whitehead, D. C. and Raistrick, N.: Ammonia volatilization from five nitrogen compounds used as fertilizers following surface application to soils, J. Soil Sci., 41, 387-394, 1990.

Zbieranowski, A. L. and Aherne, J.: Spatial and temporal concentration of ambient atmospheric ammonia in southern Ontario, Canada, Atmos. Environ., 62, 441-450, doi:10.1016/j.atmosenv.2012.08.041, 2012.

Zhu, L., Henze, D., Bash, J., Jeong, G.-R., Cady-Pereira, K., Shephard, M., Luo, M., Paulot, F., and Capps, S.: Global evaluation of ammonia bidirectional exchange and livestock diurnal variation schemes, Atmos. Chem. Phys., 15, 12823-12843, doi:10.5194/acp-15-12823-2015, 2015. 